\title{
RELATIVE USEFULNESS OF GASES OF DIFFERENT HEATING VALUE AND ADJUSTMENTS OF BURNERS FOR CHANGES IN HEATING VALUE AND SPECIFIC GRAVITY.
}

\author{
By Walter M. Berry, I. V. Brumbaugh, J. H. Eiseman, G. F. Moulton, and \\ G. B. Shawn.
}

\section{ABSTRACT.}

In connection with an investigation conducted by the Public Service Commission of Maryland to determine the most economic heating value standard for manufactured gas in the city of Baltimore, the Bureau of Standards conducted an extensive series of laboratory tests to determine primarily: (I) The relative utilization efficiency of gases of different heating value; (2) the extent to which present appliances can be adapted to give good and efficient service with gases of different heating value and composition; and (3) what adjustment in appliances is necessary to give the consumers good and efficient service when different kinds of gases are mixed and there is a variation in the composition, heating value, and the specific gravity of the gas.

The laboratory tests of gases varying in heating value from 300 to $600 \mathrm{~B}$. t. u./ft. ${ }^{3}$ indicated that the usefulness for top burner cooking is defendent almost wholly upon the total heating value per cubic foot.

Some change in size of orifice and air-shutter adjustment of burners is necessary to secure the best service when a material change is made in heating value. Most existing burners can be readily adjusted to give good service with heating values as low as 450 B. t. u. $/ \mathrm{ft}^{3}{ }^{3}$ without alterations of the burners.

Uniformity in heating value, specific gravity, and pressure are essential for the very best service, yet it is practicable to adjust burners to give satisfactory service in cities where different gases are mixed and there is considerable variation in the heating value or specific gravity.

\section{CONTENTS.}

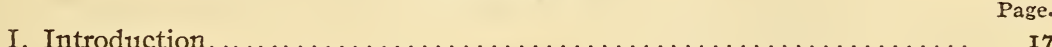

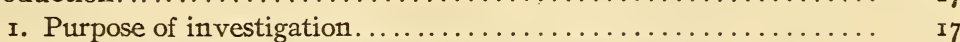

2. Scope of the laboratory tests..................... I9

II. Preparation of gas samples of different heating values. . . . . . . . 20

III. Description of apparatus and methods used in testing ........... 2 I

r. Types of burners and ranges used in testing............ $2 \mathrm{I}$

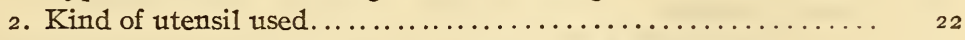

3. How the relative efficiency of the gases was determined . . . . 22

4. Apparatus and method used to test the operation of burners with

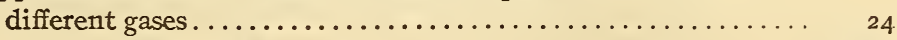

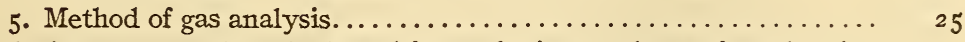

6. Apparatus and method used for analyzing products of combustion

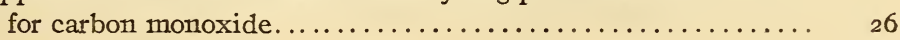


IV. Time required and cubic feet of gas used to heat 2 quarts (4.I7 $\mathrm{lbs}$.) of water to boiling, calculated efficiency of heating, and the condition of good adjustment for two types of burners.

I. Tests of " 500 " B. t. u. city gas (mixed coke oven and water gas). .

(a) Burner No. I....

(b)

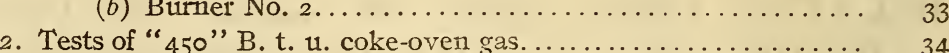

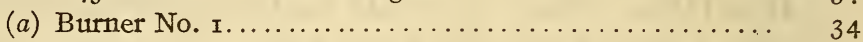

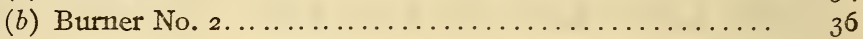

3. Tests of " $5^{2} 5$ " B. t. u. coal gas...................... 36

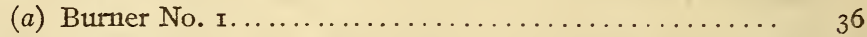

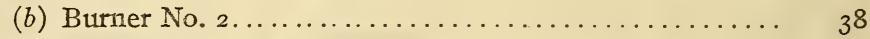

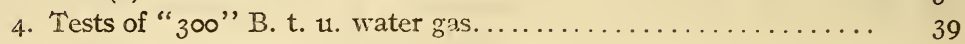

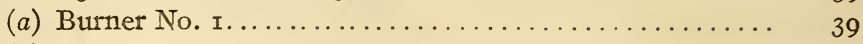

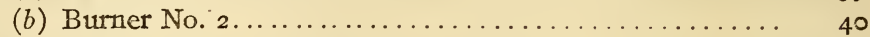

5. Tests of " 350 " B. t. u. water gas................... 4 I

(a) Burner No. I............................. 4 I

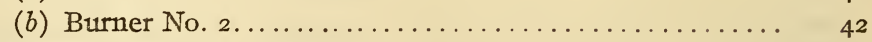

6. Tests of " 400 " B. t. u. water gas.................. 43

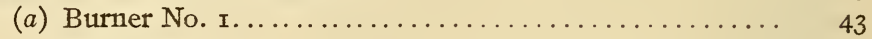

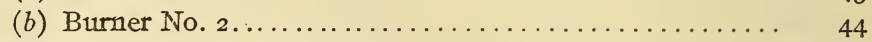

7. Tests of " 450 " B. t. u. water gas...................... 45

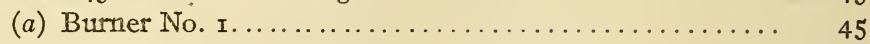

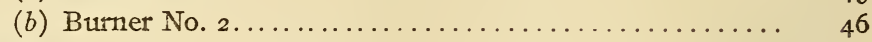

8. Tests of " 500 " B. t. u. water gas.................. 47

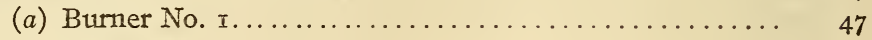

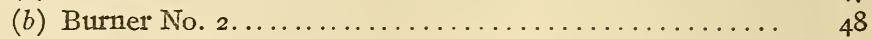

9. Tests of " $55^{\circ}$ " B. t. u. water gas................. 49

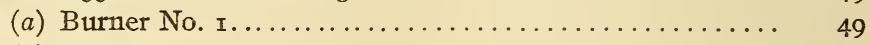

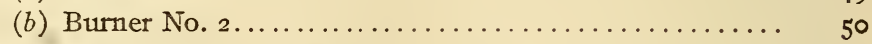

Io. Tests of " 600 " B.t. u. water gas.................... 50

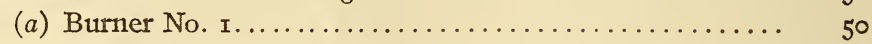

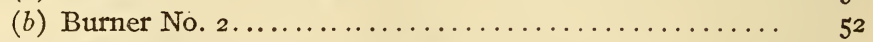

Ir. Tests for carbon monoxide in the products of combustion..... 53

I2. Summary of gas analyses........................ 53

I3. Comparison of results with gases of different heating values.... 54

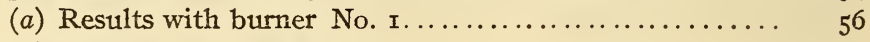

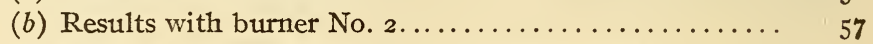

(c) Effect of room temperature on efficiency tests......... 59

I4. Adjustment of burners for gases of different heating value and

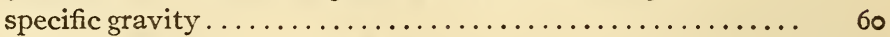

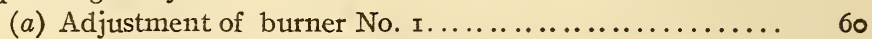

(b) Adjustment of burner No. 2.................. 60

V. Gas pressure necessary for good adjustment of burner No. I with " 500 " and " $600 "$ " B. t. u. water gas. ....................... 6 I

VI. Fffect of change in heating value on the flame characteristics and opera-

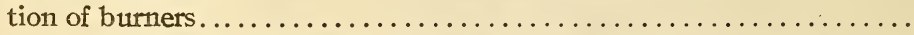

I. Comparison of air-gas ratio and B. t. u. per cubic foot of mixture with water gas of 400,500 , and $600 \mathrm{~B}$. t. u., and coal gas of $5^{25}$ B. t. u. at the upper workable limit, good adjustment, and con-

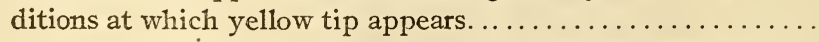

2. Flame and cone heights at different burner adjustments with 400 , 500 , and 600 B. t. u. water gas. . . . . . . . . . . . . . 
VII. Effect of change of specific gravity of gas on the operation of a burner

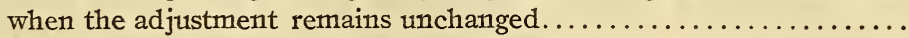

I. Effect of change from 0.40 specific gravity coke-oven gas to 0.65

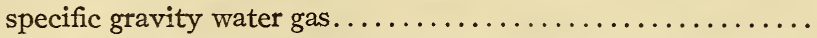

2. Effect of change from 0.65 specific gravity water gas to 0.40 specific

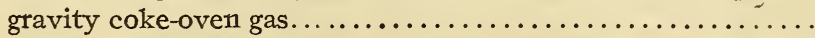

3. Suggested adjustment of gas range burners in localities where the specific gravity of the gas varies.

Page.

VIII. Efficiency of gases of different heating value with a change of distance of utensil from burner, and carbon monoxide in the products of combustion at different positions.............................. 76

I. Tests of burner No. I with 500 and 600 B. t. u. water gas....... 77

2. Tests of burner No. 3 with 500 and 600 B. t. u. water gas....... 79

IX. Effect of careful operation of gas burners on gas consumption ....... 85

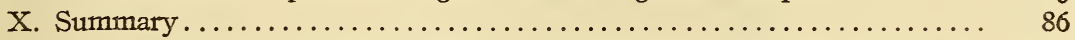

I. Relative utilization efficiency of gases of different heating value. .

2. Extent to which the present appliances can be adapted to give good and efficient service with gases of different heating value

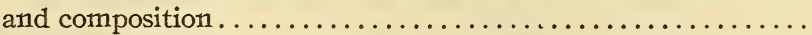

3. Adjustment in appliances necessary to give the consumers good and efficient service when different kinds of gases are mixed and the composition, heating value, and the specific gravity

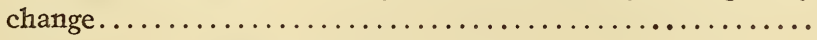

\section{INTRODUCTION.}

\section{PURPOSE OF INVESTIGATION.}

Reductions in heating value standards in many of our cities within the past two or three years are claimed to have brought about material savings in the cost of manufacture of gas and lower prices to the consumer than if the former standards had been continued. However, the reductions in standards have not always been brought about without some complaint from the consumers that the service was inferior and the total cost greater with a lower-heating value gas than with a gas of higher-heating value.

The Public Service Commission of Maryland has undertaken to investigate this matter very fully, with a view of determining the most economic and satisfactory heating-value standard for the city of Baltimore. In connection with this investigation the commission requested the Bureau of Standards to make laboratory tests to determine the relative efficiency of gases of different heating value and the adaptability of existing appliances for gases differing in heating value and composition.

While the effort was made to have the tests of the relative efficiency of gases of different heating value as practical as possible, it should be appreciated that it is exceedingly difficult to obtain 
conditions in the laboratory exactly comparable with those of the average consumer's home. Waste of gas is naturally eliminated in laboratory tests. A definite size of cooking vessel must be used in order to obtain comparable results which have any value. The utensils are clean and in good condition, as is also the stove. Finally, the tests are necessarily limited to the heating of water on top burners; and while this gives an exceedingly valuable indication, it is not necessarily a conclusive proof of the relative quantities of gas of different qualities which will be used by the conconsumers. In fact, the actual data on change of consumption of gas where change in calorific value has been made do not give results agreeing exactly with conclusions which might be drawn from laboratory tests. Diue weight should be given to this practical data in drawing any final conclusions.

The question of the relative utilization efficiency of gases of different heating values has been under consideration for several years, both in England and in this country. Exhaustive laboratory tests have been conducted on this subject by the Gas Investigation Committee of the British Institution of Gas Engineers and the Joint Committee on Efficiency and Economy of Gas of the California Railroad Commission. ${ }^{1}$ Although the conclusions from the previous laboratory tests have been generally in agreement, it was thought highly desirable to duplicate some of the tests with the gases available in Baltimore and establish carefully the conditions under which the appliances would give the maximum practical efficiency with each kind of gas.

The gas engineering section of the Bureau of Standards has been conducting tests of manufactured and natural gases for several years, and since it had a trained personnel and special testing equipment for studying the combustion of gases, it undertook to make the required laboratory tests, which form one part of the commission's investigation.

In this report the bureau gives the results of tests which show the relative efficiency of utilization of gases of different heating values and composition. The results show also the pressure required to operate the burners, and how appliances can be adapted and adjusted to give satisfactory service with gases of different heating value and specific gravity. The data showing how to adjust appliances to give good service where the relative

\footnotetext{
1. Report of the research subcommittee of the gas investigation committee of Institution of Gas Engineers (England), Gas Journal, Oct. 29, r918; Nov. 5, r9r8. Progress report of Joint Committee on Efficiency and Economy of Gas of the Railroad Commission of the State of California, Gas Age-Record, Nov. I2, I92I; Nov. 19, I92I.
} 
proportions of coal or coke-oven gas and water gas vary should have considerable practical value in many localities.

Baltimore is supplied at the present time with gas having a heating value of $500 \mathrm{~B}$. t. u./ $\mathrm{ft}^{3}{ }^{3}$. A portion of the gas is cokeoven gas, purchased by the Consolidated Gas, Electric Light \& Power Co. from the Sparrows Point plant of the Bethlehem Steel Co. The latter company is a commercial concern not subject to commission regulation and sells its gas merely as a by-product. The remainder of the supply is water gas, manufactured at the Spring Gardens plant of the Consolidated Gas, Electric Light \& Power Co. The standard of heating value in Baltimore was reduced to 500 B. t. u. in June, I920, in order to allow the economical distribution of the coke-oven gas, which has normally a heating value of about $500 \mathrm{~B}$. t. u.

\section{SCOPE OF THE IABORATORY TESTS.}

The laboratory work in Baltimore was divided into three parts, as follows:

(I) The first series consisted of numerous practical efficiency tests made with ro different kinds of gas when the gas rate and air shutter were adjusted in each case to produce a good flame. These tests were made on two different ranges and the results show the efficiency; the time required, and cubic feet of gas used to bring 2 quarts of water to boiling from an initial temperature of $80^{\circ} \mathrm{F}$.

In order to gather information on the composition of the combustible mixture within the burner at the condition of good adjustment for each gas, the burner was removed from the range after each adjustment and connected to special apparatus which had been developed for that purpose.

The condition at which the flash back and the blowing from the ports occur with each kind of gas represents a rather definite relation between velocity through the ports and composition of the air-gas mixture. The yellow tips also occur at rather definite mixtures of gas and air. These conditions were also determined with the above-mentioned apparatus.

(2) The principal object of the second series of tests was to establish more definitely the workable limits of operation of burners with gases of different heating value and specific gravity. This part of the laboratory schedule consisted of a series of tests made with water gas of 400,500 , and 600 B. t. u. and coal gas of 525 B. t. u. With each kind of water gas the burner was operated at three rates of consumption, namely, 7,000, 9,000, and I I,000 
B. t. u./hr. The cone and flame heights and the limits of adjustment within which the burner could be satisfactorily operated were observed.

This matter of correct appliance adjustment is of considerable importance in cities where coke-oven or coal gas and water gas are mixed. As a result of the daily and seasonal variations in demand it is difficult to maintain the ratio of the two gases constant and, therefore, there may be considerable variation in the specific gravity of the gas with a resulting change in air entrainment and variation in flame characteristics.

(3) The third part of the investigation consisted of a series of tests with water gas of 500 and $600 \mathrm{~B} . \mathrm{t} . \mathrm{u} . / \mathrm{ft}^{3}{ }^{3}$ to determine the position of vessel relative to the gas burner that would give the highest thermal efficiency without forming dangerous quantities of carbon monoxide. In these tests the utensil was placed at distances of $I I / 2, I I / 4, I$, and $3 / 4$ inches from the burner. Tests were made with three gas rates, 7,000, 9,000, and II,000 B. t. u./hr.

The efficiency that can be secured in top-burner cooking will depend upon the distance of burner from the utensil and upon the flame characteristics. Good flame contact is essential for rapid heating (the consumer's idea of good service) and high efficiency, but the smothering of the flame is dangerous on account of the production of carbon monoxide. At each rate and at each position of vessel the flame was adjusted for three different conditions, namely, a hard flame, a medium flame, and a soft flame. A large number of carbon-monoxide determinations were made under each condition of operation with the ordinary star and disk types of burners. The results of the tests show how the production of carbon monoxide is affected by a change in the distance between the burner and the vessel, variation in rate of gas consumption, or use of different types of burners.

\section{PREPARATION OF GAS SAMPLES OF DIFRERENT HEATING VALUES.}

In order that a sufficient volume of gas of a constant heating value be available for a series of tests a gas holder with a capacity of approximately 300 feet $^{3}$ was secured. For purification purposes the gas before entering the holder was passed through the tar scrubber and purifier shown in Figure I. The tar scrubber was $2 \mathrm{I} / 2$ feet in diameter and $\mathrm{I} 2$ feet high and was filled with dry wood shavings. This scrubber completely removed all the tar in the gas. The purifier, $2 \frac{1}{2}$ feet in diameter and 3 feet high, was 
Technologic Papers of the Bureau of Standards, Vol. 17.

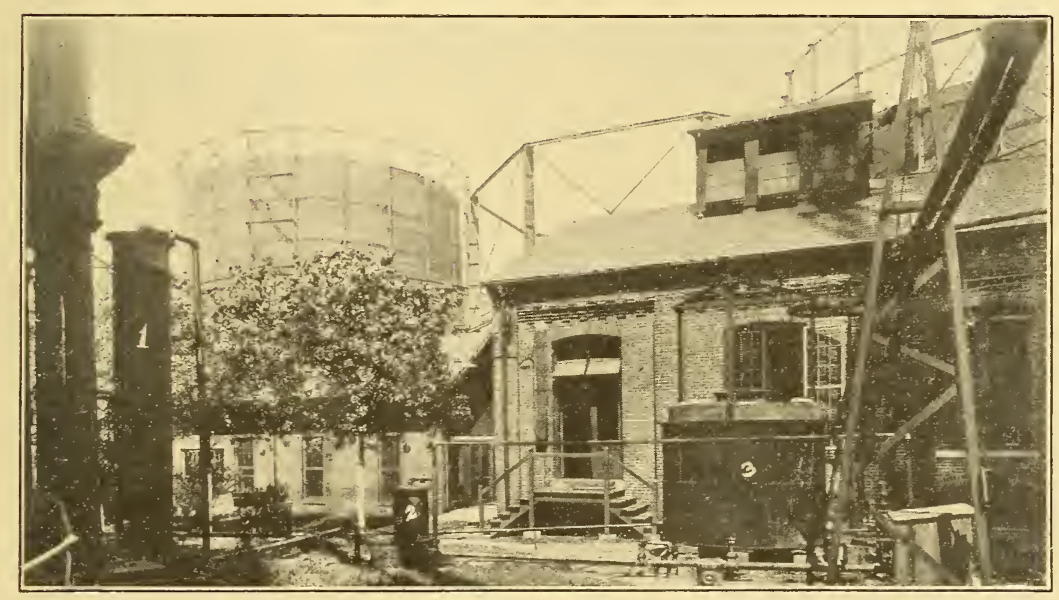

III. I.-View of tar scrubber (I), purifier (2), and gas holder (3) used in these tests. 

filled with iron oxide and wood shavings, which completely removed all traces of hydrogen sulphide.

The city gas used in our tests was piped to our holder direct from the Consolidated Gas, Electric Light \& Power Co.'s city distribution line. This gas contained approximately one-third coke-oven gas and two-thirds water gas and the heating value was approximately 500 B. t. u./ft..$^{3}$

The coke-oven gas was received from the Sparrows Point plant of the Bethlehem Steel Co. The gas as received at Baltimore was free of tar but not of hydrogen sulphide, and it was necessary to purify it before entering our holder. The coke-oven gas used in these tests had a heating value of about 450 B. t. u./ft. ${ }^{3}$

Coal gas, a gas similar to coke-oven gas but usually of somewhat higher heating value, was secured from the Philadelphia Gas Works, since there were no facilities for its manufacture in Baltimore. It was compressed and shipped in high-pressure cylinders. The heating value of the gas was about $525 \mathrm{~B}$. t. u./ft. ${ }^{3}$ when released into our holder. The gas as received was free of tar and hydrogen sulphide.

All of the water gas was manufactured at the Spring Gardens plant. A connection was made to the outlet of the wash box of a generator set and from there the gas was piped about 400 feet through a 4-inch line to a tar scrubber, purifier, and finally into the gas holder. Gases of different heating values were made by varying the quantity of gas oil sprayed into the carbureter.

\section{DESCRIPTION OF APPARATUS AND METHODS USED IN TESTING.}

\section{TYPES OF BURNERS AND RANGES USED IN TESTING.}

In the tests of this report three different designs of top burners were used and are shown in Figure 2. These burners are known as regular front top burners and are often designated as "standard" size (about 4 inches in diameter) to differentiate them from other sizes. Gas ranges of average size are generally equipped with three regular, one giant, and one simmering burner.

Bumer No. I was selected because it is the most extensively used in Baltimore and also represents the "star" type of burner.

Burner No. 2 which is of the "disk" type, was selected because it was desired to test a burner of an old design, many of which are still in service in Baitimore.

Burner No. 3 was used only in the study of the effect on efficiency with a change of distance of utensil from burner. It is one of the 
later designs of the "disk" type of burner and is much used in New York City.

The ranges which were used to determine the efficiency of gases of different heating values are shown in Figures 3 and 4 , respectively. They were obtained from consumers' premises where new ranges had been purchased.

\section{KIND OF UTENSIL USED.}

In this investigation no attempt has been made to study the effect on the efficiency if the size or shape of the utensil, relative to the size of the burner, is varied, nor the probable change in efficiency that would result from the use of utensils made from various materials or those made with different weights of material. A light-weight aluminum utensil was selected such as that shown in Figure 6. It is model No. 44-A made by the Aladdin Aluminum Co. The maximum diameter is 8.1 inches and the capacity is 4 quarts. This size of utensil was used in all the efficiency tests here reported.

\section{HOW THE RELATIVE EFFICIENCY OF THE GASES WAS DETERMINED.}

In past investigations of this bureau, tests of efficiency of heating were made by heating a given weight of water through a temperature rise of $100^{\circ} \mathrm{F}$. Before adopting the method used in this investigation, tests were made to ascertain the difference in efficiency, if any, between heating water from tap-water temperature through $100^{\circ} \mathrm{F}$. rise or from tap-water temperature to boiling. The effect of stirring the water during heating was also determined. The results were as follows: Two quarts of water heated to boiling, stirred, gave 36.8 per cent efficiency; 2 quarts of water heated to boiling, not stirred, gave 36.5 per cent efficiency; and 2 quarts of water heated through $100^{\circ} \mathrm{F}$. gave 37.5 per cent efficiency.

It is apparent from the above that stirring the water does not appreciably alter the efficiency, nor is the efficiency of heat absorption much different whether the water is heated over a greater or less difference in temperature.

It is also of interest to know whether the rate of heat absorption is constant from the time the utensil is placed over the burner until boiling begins. The curves of Figure 5 show that the rate of heat absorption is constant and depends directly upon the rate of supply of heat.

To make the tests here reported the following method was selected. Two quarts (4.I 7 pounds) of water were heated from 
Technologic Papers of the Bureau of Standards, Vol. 17.

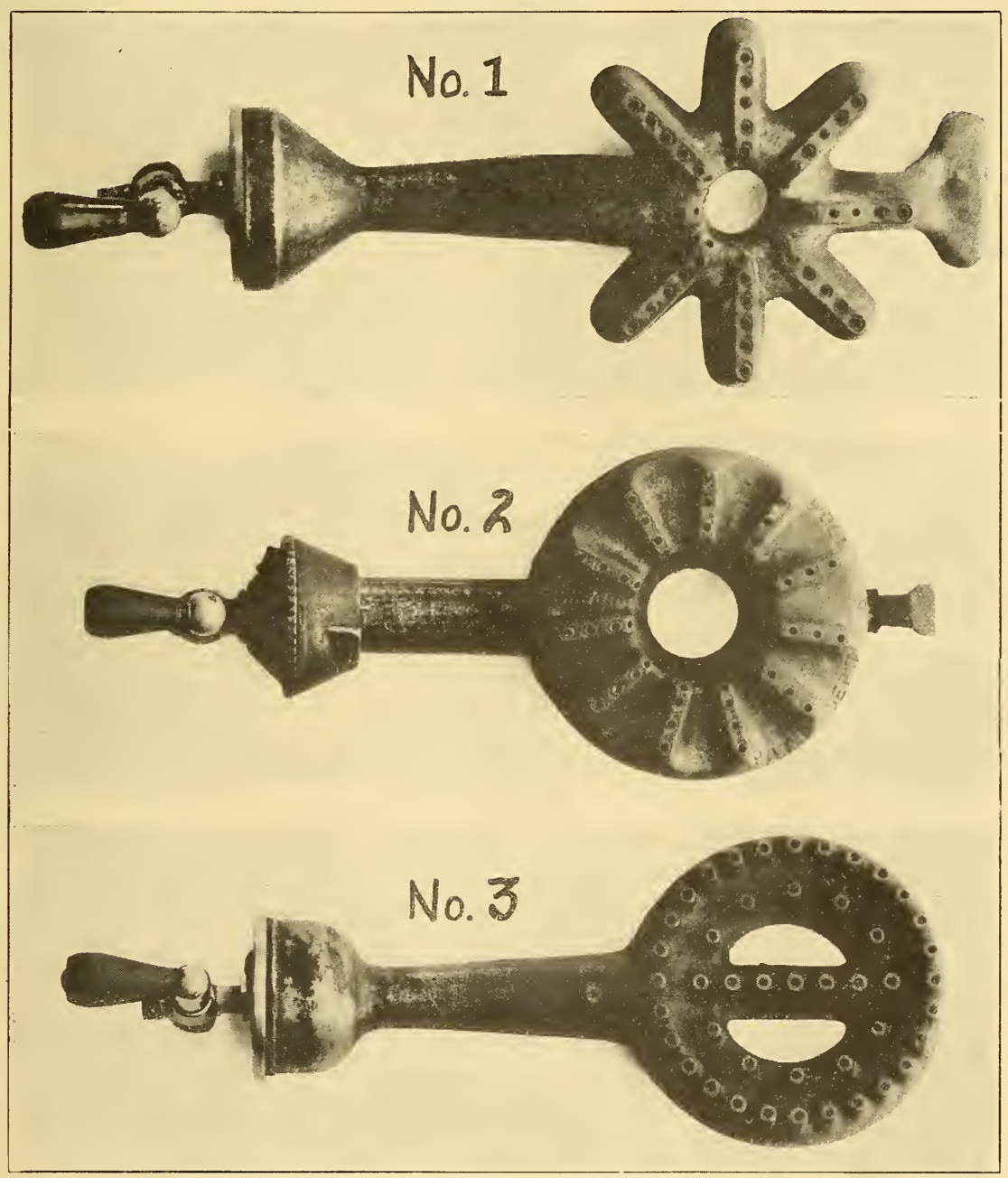

FIG. 2.-Top view of burners used in the tests.

Burner No. I "star" type, burner No. 2 old "disk" type, and burner No. 3 new "disk" type. 
Technologic Papers of the Bureau of Standards, Vol. 17.

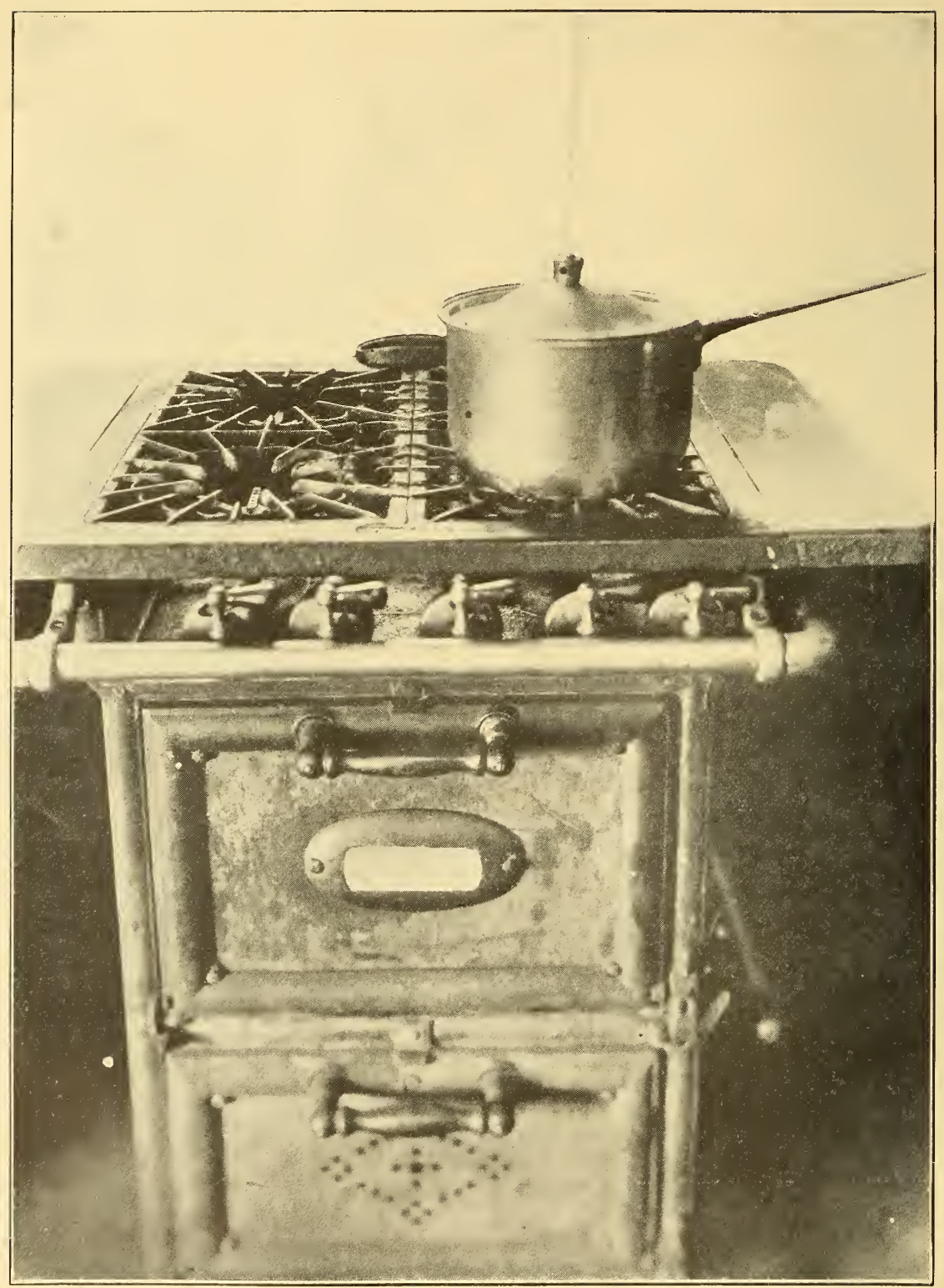

FIG. 3.-Gas range equipped with burner No. I showing utensil used in efficiency tests. 
tap-water temperature to boiling. The initial temperature was very carefully noted just before the utensil was placed over the burner. At the instant the utensil was placed over the burner the gas meter reading was taken. The observer who placed the utensil over the burner watched the water temperature until it just reached the boiling point when he signaled to the person who read the gas meter.

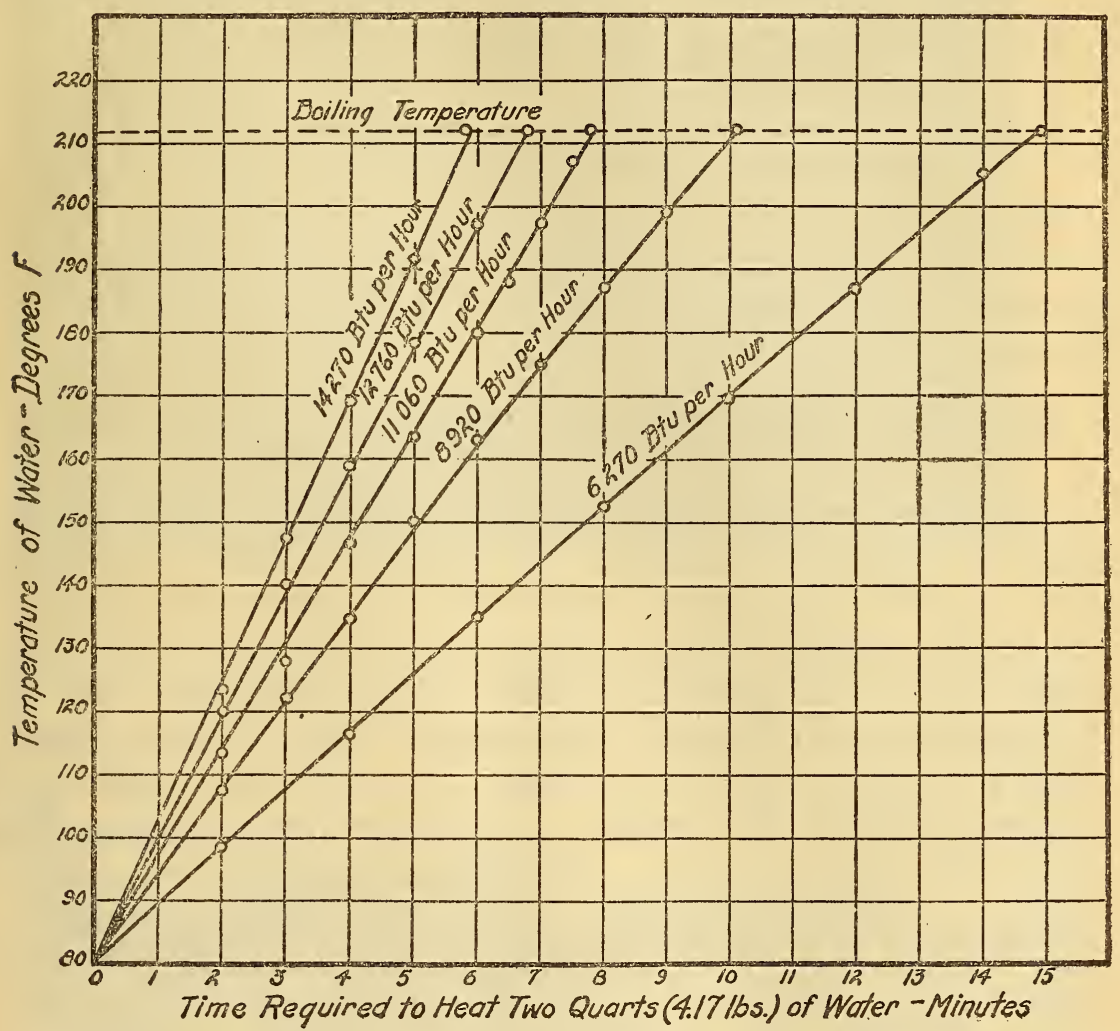

FIG. 5.-Curves showing the variation of rate of heating water with different B.t.u. rates.

Burner No. I was used to make the tests and was placed $x^{3} / 8$ inches from the utensil shown in Fig. 3 .

During a test the gas temperature, the pressure of the gas in the meter, and the barometric pressure were noted. The difference between the meter readings at the time the utensil was placed over the burner and at the time the water reached $212^{\circ} \mathrm{F}$. gave the uncorrected volume in cubic feet of gas consumed. This volume was then corrected to the standard barometric condition of 30 inches of mercury pressure at $60^{\circ} \mathrm{F}$. The efficiency was calculated on the basis of the quantity of heat absorbed by the water relative to the total quantity of heat contained in the gas con- 
sumed. No allowance was made for the heat absorbed by the utensil. The efficiency may, therefore, be computed from the simple equation,

where

$$
\text { Efficiency }=\frac{W \times T}{\text { B.t. u. per cubic foot } \times V \times F}
$$

$W=$ weight of water, $4 . I 7$ pounds (2 quarts) in the case of the tests of this report.

$T=$ temperature rise of water, degrees $\mathrm{F}$.

$V=$ uncorrected volume of gas consumed.

$F=$ correction factor which reduces uncorrected volume to 30 inches of mercury pressure at $60^{\circ} \mathrm{F}$.

The efficiency values shown in this paper are an average of two tests at each position. By making two tests errors in reading the gas meter or the thermometer or in weighing the water would be detected.

\section{APPARATUS AND METHOD USED TO TEST THE OPERATION OF BURNERS WITH DIFFERENT GASES.}

The set-up used in making the tests of operation of purners is shown in Figure 6. There are two meters, a 5-light wet meter used to meter the gas and a Io-light wet meter for metering the air. After being metered, the gas passes by an opening to a gas bag which serves to eliminate any slight pressure irregularity due to the operation of the meter mechanism. The gas then passes through a pressure regulator by which it is possible to regulate the pressure desired at the orifice. A regulator and a gas bag are placed before the air meter. The regulator reduces the air-line pressure, while the gas bag removes some of the fluctuations caused by the air compressor. Between the air meter and the connection to the wooden box is another gas bag which removes the remaining fluctuations in the air line. After this gas bag is a valve which is used to regulate the flow of air. The mixer portion of the gas burner is sealed in the end of the box opposite the point at which the gas line enters. The gas-line pressure is taken at a point just back of the orifice and is connected to a pressure gauge outside of the box. The air line is joined to the box directly above the point at which the gas line enters. A baffle is placed in front of the air inlet in order to reduce the velocity of the air as it enters the box. The box has a removable lid and is made air-tight. On one side of the box a hole 6 inches square is cut, and a piece of shellacked paper is glued over the opening to form an explosion 
Technologic Papers of the Bureau of Standards, Vol. 17.

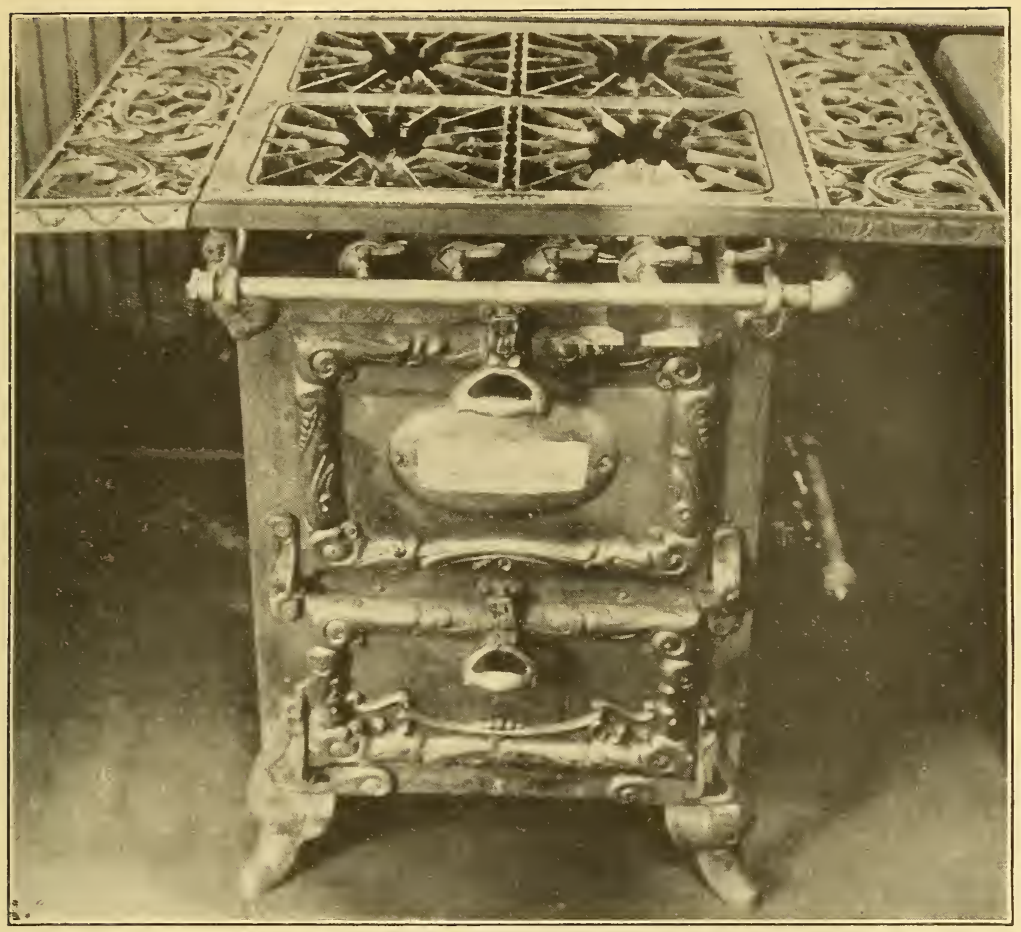

FIG. 4.-Gas range equibped with burner No. 2 used in efficiency tests.

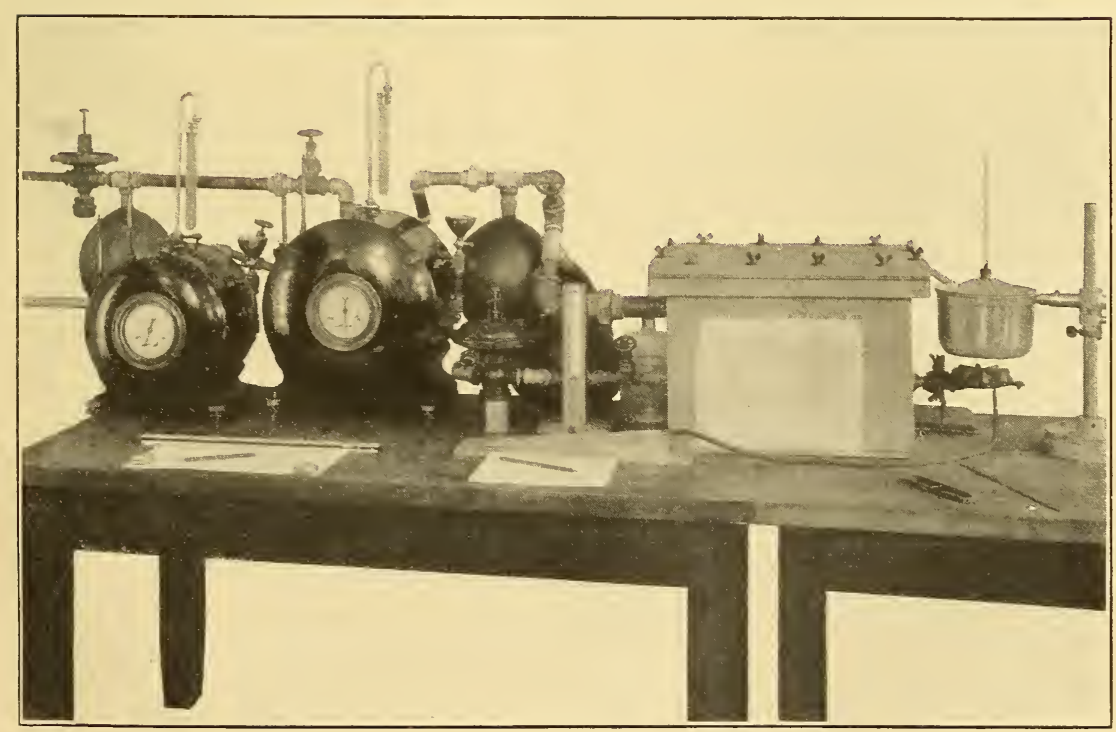

FIG. 6.-Apparatus used to determine the primary air that was injected into a burner at any condition of operation. 
Technologic Papers of the Bureau of Standards, Vol. 17.

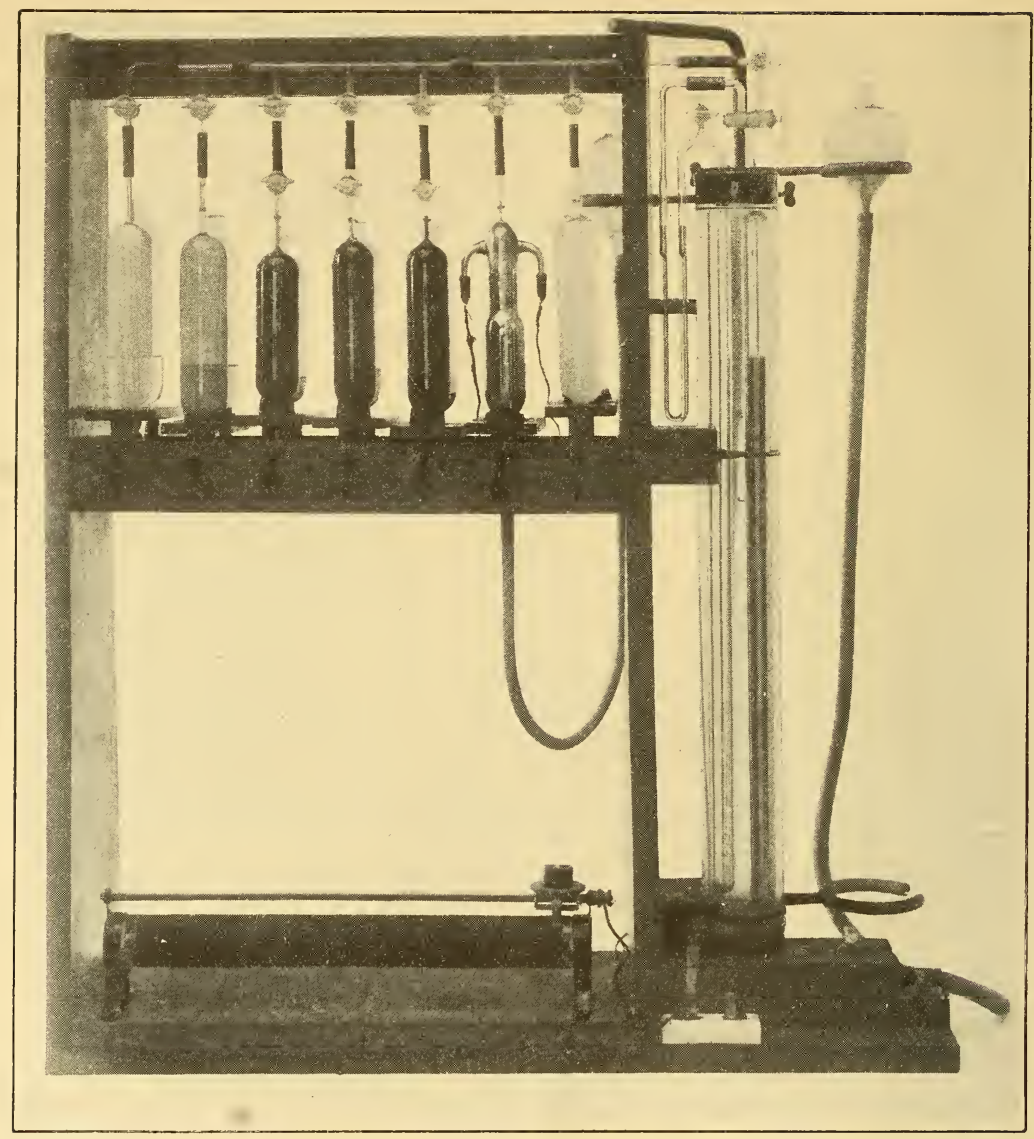

FIG. 7.-Orsat gas analysis apparatus used to determine the constituents of the gases.

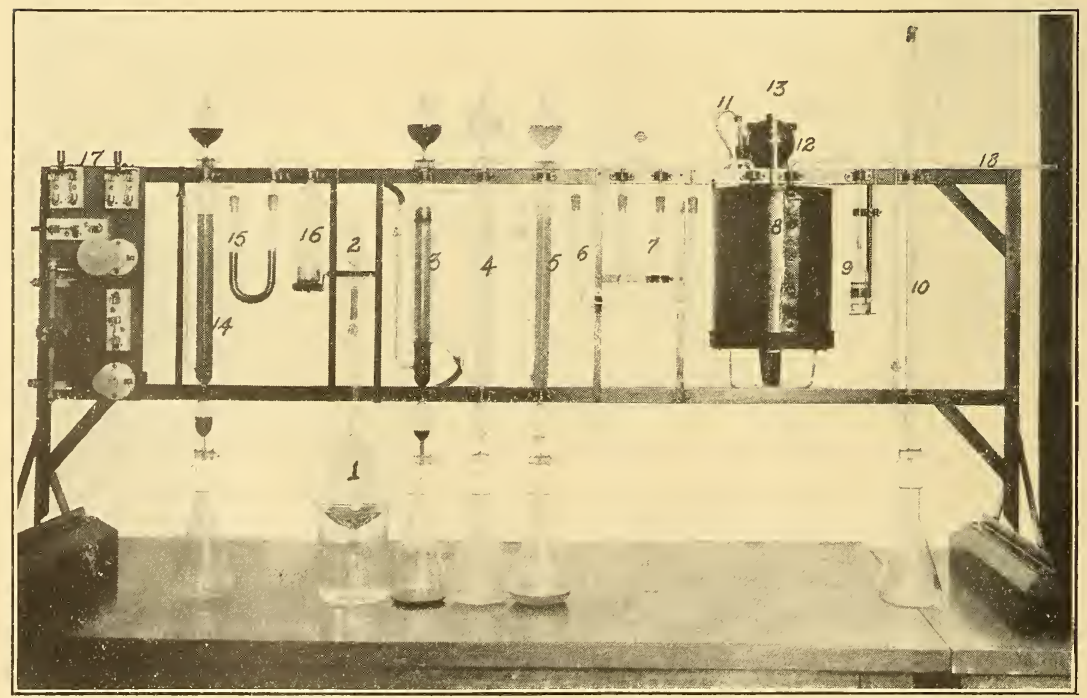

FIG. 8.-A pparatus used for analyzing products of combustion for carbon monoxide. 
head. A very sensitive slope $U$ gauge is constructed to measure the extremely minute pressures that occur in the burner. Xylene is used in this gauge because it does not adhere to the wall of the $U$ tube.

With the apparatus which has been described it is possible to produce in the burner any desired air-gas mixture. Because it is impossible to operate a burner above an air-gas ratio that will cause the flames to leave the ports or flash back into the burner, and it is impracticable to operate the burner with a primary air-gas ratio which produces a yellow flame, these conditions were determined when testing a burner. To make the tests, the lid was placed on the box, and air was metered into the box at rates which produced these conditions for different gas rates. The ratio of the volume of air to the volume of gas that entered the burner was readily calulated by timing the two meters.

The amount of air which was injected into the burner at different pressures for any definite air-shutter adjustment was also determined. This was accomplished by first operating the burner normally, with the top of the box removed, and observing carefully the orifice pressure and the pressure in the burner as indicated on the very sensitive slope $U$ gauge. The lid was then placed on the box and the air passed through a meter into the box at a rate which exactly duplicated the previous condition of pressure within the burner. It is evident that since the gas rate in each case was the same, the volume of air injected into the burner in each case must have been the same. The primary air-gas ratio for gas pressures of $0.25,0.5, \mathrm{I}, 2,3,4$, and 5 inches was thus obtained.

Before beginning a test the gas was lighted long enough for the burner to be heated to its normal temperature. All tests herein reported, therefore, were obtained with the "burner hot."

\section{METHOD OF GAS ANALYSIS.}

An Orsat type of gas analysis apparatus was used for analyzing the various gases used in the tests, also for the determination of the amount of carbon dioxide and oxygen in the products of combustion as sampled above the burner. The apparatus as used is shown in Figure 7.

Miercury was used as the confining liquid in the gas measuring burette. By means of the method of compensation all volume measurements were made at a temperature and pressure that are constant for any analysis. The absorbable constituents were 
removed by using the following reagents in the several pipettes: (I) Sodium hydroxide solution for the removal of carbon dioxide $\left(\mathrm{CO}_{2}\right)$; (2) fuming sulphuric acid for the removal of the illuminants; (3) alkaline pyrogallol solution for the removal of oxygen $\left(\mathrm{O}_{2}\right)$; and (4) acid cuprous chloride for the removal of carbon monoxide (CO).

The amounts of hydrogen $\left(\mathrm{H}_{2}\right)$ and methane $\left(\mathrm{CH}_{4}\right)$ were determined by the slow combustion method. The amount of ethane $\left(\mathrm{C}_{2} \mathrm{H}_{6}\right)$ present in the gases was not determined separately, but the amount being small the error introduced by including it with the percentages of hydrogen and methane present may be ignored.

\section{APPARATUS AND METHOD USED FOR ANALYZING PRODUCTS OF COMBUSTION FOR CARBON MONOXIDE.}

The amount of carbon monoxide (CO) present in the products of combustion is important as a criterion of the completeness of combustion and of the safe and efficient operation of a burner. A careful analysis of the products of combustion for carbon monoxide was made using the apparatus shown in Figure 8 . The general arrangement of apparatus is practically the same as that used by Larson and White, who did considerable work on the quantitative determination of carbon monoxide while in the Chemical Warfare Service. The method is based on the reaction of carbon monoxide (CO) and iodine pentoxide $\left(\mathrm{I}_{2} \mathrm{O}_{5}\right)$, which results in the liberation of iodine and the formation of carbon dioxide $\left(\mathrm{I}_{2} \mathrm{O}_{5}+{ }_{5} \mathrm{CO}=\mathrm{I}_{2}+{ }_{5} \mathrm{CO}_{2}\right)$. The liberated iodine is absorbed in potassium iodide (ro per cent solution) and the amount is determined by titration with carefully standardized sodium thiosulphate $\left(\mathrm{Na}_{2} \mathrm{~S}_{2} \mathrm{O}_{3}\right)$. Since the amount of liberated iodine and the volume of sample passed through the apparatus is known, the amount of carbon monoxide in the products of combustion as sampled can be calculated.

In order to get a result that is comparable with that for any other burner, the products of combustion are analyzed for content of carbon dioxide and oxygen by means of the Orsat apparatus. The amount of oxygen in the sample is directly related to the air present, namely, where $x=$ amount of oxygen in the sample, and since normal air contains 20.93 per cent oxygen by volume, then $\frac{20.93-x}{20.93}=$ per cent of products of combustion free from air.

Using this factor we can calculate the per cent of carbon monoxide and carbon dioxide-on the air-free basis. The calculation of the 
carbon monoxide produced in cubic feet per hour is made as follows:

Let $a=$ per cent of $\mathrm{CO}$ (air-free basis).

$b=$ per cent of $\mathrm{CO}_{2}$ (air-free basis).

$C=\mathrm{CO}_{2}$ produced by combustion of $\mathrm{I}$ foot $^{3}$ of gas.

$R=$ rate at which gas is burned in cubic feet per hour

then

$\frac{a}{a+b} \times C \times R=$ cubic feet of carbon monoxide produced per hour.

Referring to Figure 8, the path of travel of the sample of the products of combustion will be traced as the sample is drawn through the apparatus by suction, connection for which is made at 18 . The sample of the products of combustion is contained in the sampling tube (I) and is displaced by means of water. As the water rises in the sampling tube (I) and displaces the sample it ultimately acts on the float valve (2) which automatically cuts off the flow of water and allows the purging with air to begin. The sample passes through absorption towers filled with glass beads containing, respectively, chromic acid (3), sodium hydroxide (4), and concentrated sulphuric acid (5). The absorption tower containing chromic acid is heated to approximately $2 \mathrm{I} 2^{\circ} \mathrm{F}$ by means of a steam jacket. The hot chromic acid will remove any illuminants, should there be any present; while the sodium hydroxide will remove the carbon dioxide $\left(\mathrm{CO}_{2}\right)$ and the sulphuric acid will absorb most of the moisture. The U-tube (6) contains stick sodium hydroxide $(\mathrm{NaOH})$ and acts as a guard tube for the absorption tower of sulphuric acid and it also will remove any trace of carbon dioxide that might still be in the sample. The next $U$-tube $(7)$ contains phosphorous pentoxide $\left(\mathrm{P}_{2} \mathrm{O}_{5}\right)$ where the last trace of moisture is removed. The unit marked " 8 " is an oil bath in which is mounted a U-tube containing alternate layers of iodine pentoxide and glass wool. The bath is heated by an electric immersion type heater (II) to a temperature of $310^{\circ} \mathrm{F}$. ( $55^{\circ}$ C.) and a uniform temperature is maintained by means of a stirring motor (12). The liberated iodine is absorbed in a potassium-iodide solution contained in a Gomberg bulb (9). The Gomberg absorption bulb is attached by ground-glass joints so that it can be easily removed and the iodine solution rinsed into a flask for titration with standardized sodium-thiosulphate solution. The air used in purging passes through an absorption tower containing concentrated sulphuric acid ( $\mathrm{I}_{4}$ ), and a U-tube filled with 
activated charcoal for the removal of any carbon monoxide that might be in the room atmosphere. The mercury trap (16) acts as a seal when the sample is drawn into the apparatus and also prevents dust in the charcoal from being carried over by the air used in purging. The electric heater and stirring motor are controlled by means of a rheostat and lamps mounted on the switchboard (I 7 ) at the extreme left.

The method used in sampling the products of combustion is fully described in "Carbon monoxide in the products of combustion fron natural gas burners," by I. V. Brumbaugh and G. W. Jones. Figure 9 shows the apparatus used.

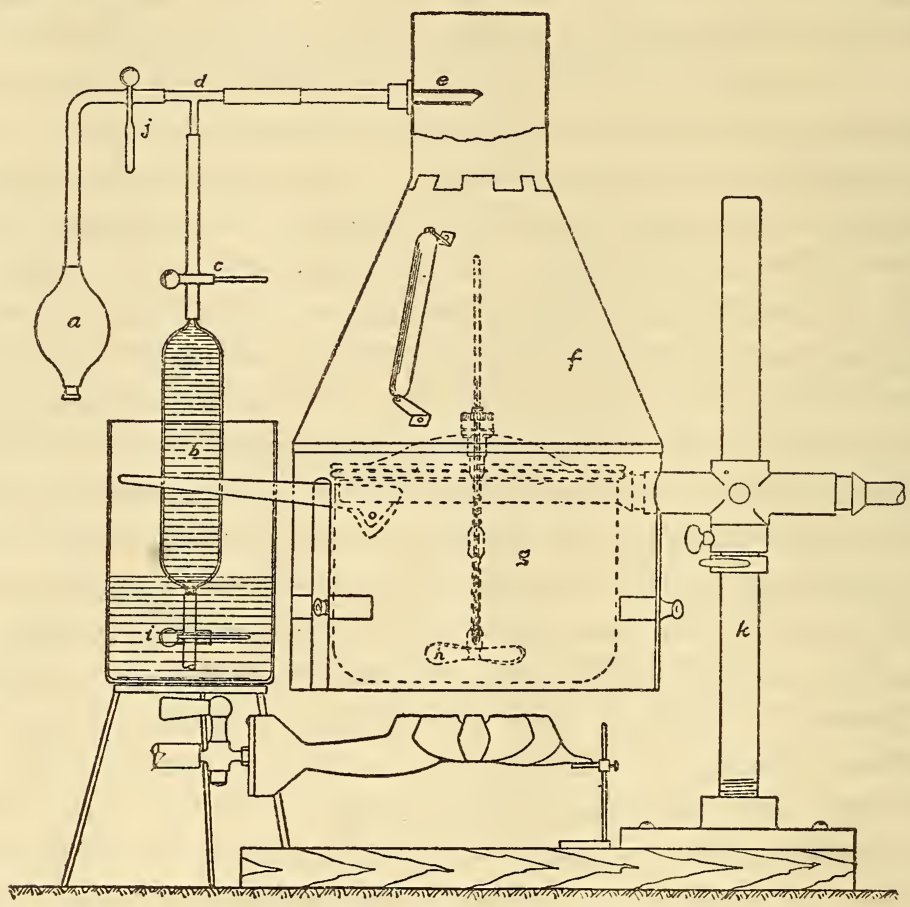

FIG. 9.-A pparatus used for sampling products of combustion.

IV. TIME REQUIRED AND CUBIC FEET OF GAS USED TO HEAT 2 QUARTS (4.17 LBS.) OF WATER TO BOILING, CALCULATED EFFICIENCY OF HEATING, AND THE CONDITION OF GOOD ADJUSTMENT FOR TWO TYPES OF BURNERS.

It has been often said that laboratory tests are made with such high degree of accuracy and refinement in adjustment that the application of the results to actual practice is very difficult. Every effort was made in this series of efficiency tests of gases of 
Io different heating values to make the condition of test as practical as possible. The tests of each gas were made on each of the ranges shown in Figures 3 and 4. The burners were adjusted in the way that a practical gas fitter would adjust the appliance in a consumer's home.

In Baltimore the pressure of the gas when supplied at the consumers' appliances averages about 3 inches. The initial adjustment of the burners for each kind of gas was made for that pressure. After the careful initial adjustment no other changes were made in the gas orifice or air shutter when the burner was operated at other pressures.

To make a good adjustment the gas-line pressure was first set for 3 inches; then the orifice was so reamed (if necessary) and the air shutter so set that a flame was obtained which was distinctly blue, with a pronounced blue inner cone. The type of flame with good adjustment of gas and primary air might be described as a "normal flame." The flame was neither "hard and stiff" nor "soft and flimsy."

In this connection the reader must bear in mind that when a burner is adjusted for the right kind of flame at a pressure of 3 inches and the pressure is then reduced to I inch or increased to 5 inches, the type of flame is not visibly altered but the rate of flow of gas and, therefore, the size of the flame with each pressure is decidedly different.

Complaints of poor service are often made when the gas pressure is adequate and the capacity of the service pipe is sufficient, but the orifice on the appliance is too small to deliver the desired amount of gas. On the other hand, complaints arise when the demand for gas is greater than the capacity of the service pipes. It is almost impossible to maintain an absolutely uniform pressure at all times, and tests of efficiency with each kind of gas were made, therefore, when gas was supplied at pressures of I, 2, 3, 4, and 5 inches. The results obtained are plotted on the curves of the various figures and are marked "efficiency," where efficiency in per cent is plotted as the ordinate with gas-line pressure in inches of water as the abscissa.

The time required to heat the water ( 2 quarts) from initial temperature to boiling was noted in each case. The time required to heat from $80^{\circ} \mathrm{F}$. to boiling was then calculated. These are the time values shown in the tables and are the same as those which have been plotted and are labeled "Time required to heat 2 quarts of water to boiling."

$110180^{\circ}-22-2$ 
From the amount of gas used and the time required for a test the gas rate in cubic feet per hour was determined. The results are shown in the tables and also in the various figures by the curves marked "Rate, cubic feet per hour."

The above procedure was followed and the results plotted in a similar manner with each of Io different gases.

After the efficiency tests of each kind of gas had been completed, the burner with the same gas cock and orifice was connected to the burner-testing apparatus without changing the adjustment of the air shutter. With this apparatus the amount of primary air injected into the burner by the gas, with the air shutter set for "good adjustment," was determined at pressures ranging from 0.25 inch to 5 inches. These values are shown by the curves marked "Primary air-gas ratio obtained with good adjustment."

If too much primary air is injected into a burner, the flames will blow from the ports or flash back. From previous experience of the bureau in work for commissions and municipalities it may be stated that when operating burners under these conditions the public will complain of "air in the gas," "poor gas," and popping of burners. The burners were operated with each kind of gas under varying gas rates and the amount of air determined which would cause the flames to just leave the ports or to flash back into the burner at each gas rate. The dashed line labeled "flames blow from ports" and "flash back" show at what rate of consumption and ratios of primary air to gas this complaint could occur with the different gases. It will be observed that the curve showing the condition of good adjustment for each kind of gas falls well below the curves for "flash back" and "flames blow from ports."

Since the velocity of combustion varies with the composition of the gas, and the velocity of the mixture through the ports varies with the port area of the burner, the ratios at which the "flash back" and "blow from ports" conditions occur will vary with the kind of gas, the heating value, the rate of consumption, and the type of burner.

If only a certain ratio of air to gas is admitted into the burner with the gas, a yellow-tipped flame will result. The values of the air-gas ratios at which this condition occurs are shown for the different kinds of gases by the curves marked "Yellow tip appears at this ratio." Such a flame will generally blacken the utensil and is likely to liberate poisonous products. The housewife strenuously objects to a flame that blackens utensils. 
The amount of air required for the complete combustion of I foot ${ }^{3}$ of gas is calculated from the analysis of the gas and is indicated by a dashed line marked "Ratio required for complete combustion" on the figures that follow. The average height of the flame and the blue inner cones were measured at the time of each efficiency test. The average height of the flame is very difficult to determine and the values shown in the tables are only approximate. The height of the biue inner cone is very definite and easily measured.

\section{TESTS OF "500" B. T. U. CITY GAS (MIXED COKE-OVEN AND WATER} GAS).

(a) BURNER NO. 1.

The pressure was set at 3 inches; then the size of the gas orifice and the opening of the air shutter of the burner were adjusted to obtain the type of flame which appliance fitters consider will give the best service. With this adjustment the air shutter was about 20 per cent open. Without changing the burner adjustments, efficiency tests were made at pressures of $\mathrm{I}, 2,3,4$, and 5 inches:

In Table 2 are given the rate of consumption in cubic feet per hour, B. t. u. per cubic foot, B. t. u. delivered per hour, cone and flame height, minutes required to heat 2 quarts of water from $80^{\circ}$ F. to boiling, the cubic feet of gas used, and the efficiency obtained at the above five pressures. The values of efficiency, rate of consumption in cubic feet per hour, and the time required to heat 2 quarts (4.I 7 pounds) of water from $80^{\circ} \mathrm{F}$. to boiling are plotted in Figure Io.

The burner, with the same gas cock, orifice, and air-shutter adjustment, was connected to the burner-testing apparatus to determine how much of the air required for combustion entered the burner through the air-shutter opening. The airinjection tests are plotted in Figure II and connected by solid lines and labeled "Primary air-gas ratio obtained with good adjustment." Let us consider the case when the burner was operated at a pressure of 3 inches and the gas rate was $22.7 \mathrm{feet}^{3} / \mathrm{hr}$. The test showed that 52.2 feet $^{3}$ of air per hour were injected into the burner. The ratio of primary air to gas was 52.2 divided by 22.7, which equals 2.3. This is the value plotted on the curve and marked " 3 in." The other points of the curve show the ratios obtained at other pressures.

From the analysis of city gas given in Table I it was computed that the oxygen from 4.26 feet $^{3}$ of air is required to completely 
burn a cubic foot of the gas. This value is shown by the dashed line of Figure I I labeled "Ratio required for complete combustion."

Referring again to the rate of consumption at 3 inches pressure, the total air required for complete combusion was $22.7 \times 4.26=96.7$ feet $^{3}$ of air per hour, or $96.7-52.2=44.5$ feet $^{3}$ of air per hour supplied as secondary air.

It will be noted in Figure II that the burner will not flash back under any condition when the gas rate exceeds $6 \mathrm{feet}^{3} / \mathrm{hr}$. Beyond this rate the flames will leave the port when the air-gas ratio is high enough to make the velocity of the mixture through the ports greater than the velocity of combustion. The ratio at which the flames leave the ports is plotted for varying gas rates in the curve marked "Flames blow from ports" in Figure I I.

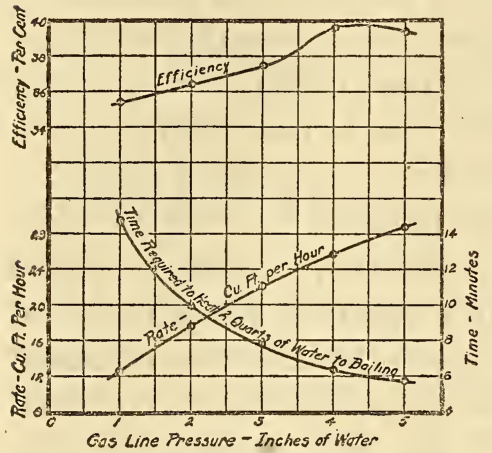

FIG. Io.-Curves showing efficiency, time required, and cubic feet of gas used to heat 2 quarts of water to boiling with city gas of 492 B. t. u. and burner No. I.

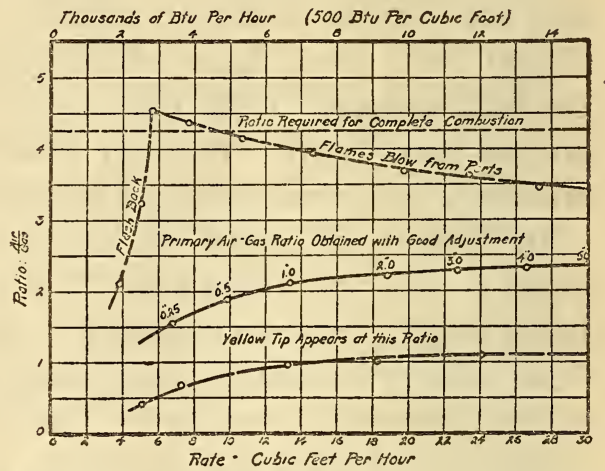

FIG. II.-Primary air-gas ratio obtained with city gas of 495 B.t. u. and burner No. I at the different conditions of operation.

Specific gravity of gas, 0.628 .

The reader will observe in Figure in that the air-gas ratio at the good adjustment with any gas rate is well below that at which the "flames blow from ports" or the "flash back" occurs and is well above the ratio at which yellow tips appear at the top of the blue inner cone.

TABLE 1.-Average Analysis of " $500 "$ B. t. u. City Gas" Used in Tests.

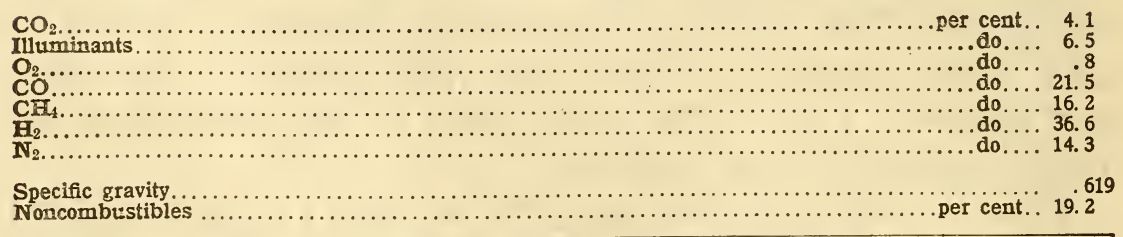

1 City gas consisted of approximately one-third coke-oven gas and two-thirds water gas. 
TABLE 2.- "500" B. t. u. City Gas, 0.618 Specific Gravity-Burner No. 1, 48 Ports, INo. 40 Drill-Utensil $13 / 8$ Inches from Burner.

\begin{tabular}{|c|c|c|c|c|c|c|c|c|}
\hline $\begin{array}{l}\text { Pressure in } \\
\text { inches } \\
\text { of water. }\end{array}$ & Gas rate. & $\begin{array}{l}\text { Heating } \\
\text { value. }\end{array}$ & $\begin{array}{c}\text { Quantity of } \\
\text { heat } \\
\text { supplied. }\end{array}$ & $\begin{array}{c}\text { Cone } \\
\text { height. }\end{array}$ & $\begin{array}{l}\text { Flame } \\
\text { height. }\end{array}$ & $\begin{array}{c}\text { Time } \\
\text { required } \\
\text { to heat } \\
2 \text { quarts of } \\
\text { water from } \\
80 \text { to } 212^{\circ} \mathrm{F} \text {. }\end{array}$ & $\begin{array}{l}\text { Gas } \\
\text { used. }\end{array}$ & $\begin{array}{l}\text { Effi- } \\
\text { ciency. }\end{array}$ \\
\hline $\begin{array}{l}1 \\
2 \\
3 \\
4 \\
5\end{array}$ & $\begin{array}{c}\text { Ft. }{ }^{3} / \mathrm{hr} . \\
12.74 \\
17.95 \\
22.48 \\
25.95 \\
29.08\end{array}$ & $\begin{array}{c}\text { B. t. u. } \text { fft. }^{3} \\
491 \\
497 \\
491 \\
491 \\
491\end{array}$ & $\begin{array}{c}\text { B. t. u./hr. } \\
6,255 \\
8,920 \\
11,040 \\
12,740 \\
14,270\end{array}$ & $\begin{array}{c}\text { Inch. } \\
0.28 \\
.38 \\
.44 \\
.50 \\
.55\end{array}$ & $\begin{array}{c}\text { Inches. } \\
0.70 \\
.94 \\
1.16 \\
1.35 \\
1.45\end{array}$ & $\begin{array}{c}\text { Minutes. } \\
14.88 \\
10.13 \\
7.97 \\
6.52 \\
5.85\end{array}$ & $\begin{array}{l}\text { Feet. }^{3} \\
3.16 \\
3.03 \\
2.98 \\
2.82 \\
2.84\end{array}$ & $\begin{array}{c}\text { Per cent. } \\
35.5 \\
36.5 \\
37.6 \\
39.8 \\
39.6\end{array}$ \\
\hline
\end{tabular}

(b) BURNER NO.2.

The same orifice that was used with Burner No. I to test " 500 " B. t. u. city gas was connected to Burner No. 2. The air shutter was then completely closed to make the good adjustment. It should be noted that the mixer of Burner No. 2 (see Fig. 2) is a separate casting into which the injecting or mixer tube makes a loose fit, the slot for the set screw of the air shutter is uncovered when the shutter is closed, and the air-shutter cap is not tight

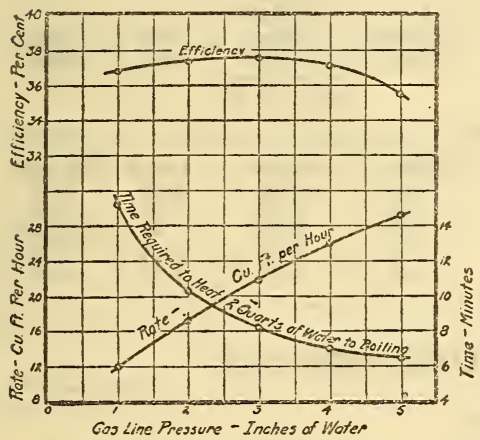

Firg. I2.-Curves showing efficiency, time required, and cubic feet of gas used to heat 2 quarts of water to boiling with city gas of 492 B. t. u. and burner No. 2.

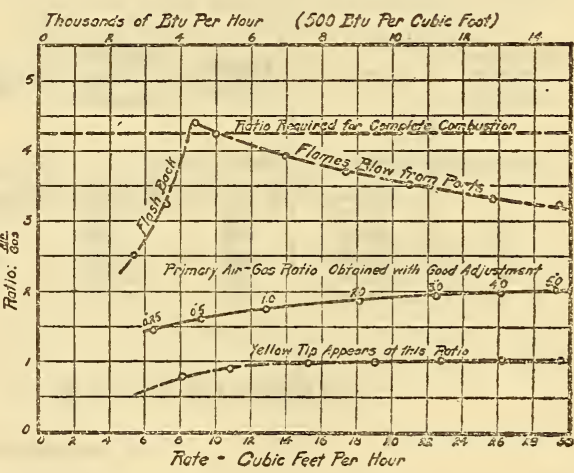

FIG. I3.-Primary air-gas ratio obtained with city gas of 495 B. t. u. and burner No. 2 a the different conditions of operation.

Specific gravity of gas, 0.628 .

against the mixer face. These openings alone allowed a sufficient amount of primary air to enter the burner at the good adjustment.

The efficiency values, etc., are given in Table 3 . If one will compare the results of the tests of city gas obtained with Bumer No. 2 with those of Burner No. I, it will be noted that there is no appreciable difference. This is due primarily to the fact that both burners were the same distance from utensil ( $13 / 8$ inches) and the 
type of flame with each was approximately the same as shown by the cone heights given in Tables 2 and 3 . Since the same orifice was used when testing with each burner the same gas rates are obtained at corresponding pressures, and since the efficiency in each case is approximately the same, it follows that there should be no appreciable difference in the time required to heat a given amount of water to boiling at a given pressure. The curves of Figures Io and I 2 verify this since they are almost identical.

The operation tests of Burner No. 2 are shown by Figure I3. The location of the curves are very similar to those of Figure II, showing the test of Burner No. I. The curve showing the "primary air-gas ratio obtained with good adjustment" is a little lower than that for Burner No. I. Those who made the adjustment believed they had exactly duplicated the flame used in the tests of Burner No. I, but there is some question whether the eye can detect any less variation in the type of flame.

TABLE 3.-“"500" B. t. u. City Gas, 0.624 Specific Gravity-Burner No. 3, 44 Ports, No. 40 Drill-Utensil $13 / 8$ Inches from Burner.

\begin{tabular}{|c|c|c|c|c|c|c|c|c|}
\hline $\begin{array}{l}\text { Pressure in } \\
\text { inches } \\
\text { of water. }\end{array}$ & Gas rate. & $\begin{array}{l}\text { Heating } \\
\text { value. }\end{array}$ & $\begin{array}{c}\text { Quantity of } \\
\text { heat } \\
\text { supplied. }\end{array}$ & $\begin{array}{c}\text { Cone } \\
\text { height. }\end{array}$ & $\begin{array}{l}\text { Flame } \\
\text { height. }\end{array}$ & $\begin{array}{c}\text { Time } \\
\text { required } \\
\text { to heat } \\
2 \text { quarts of } \\
\text { water from } \\
80 \text { to } 212^{\circ} \mathrm{F} \text {. }\end{array}$ & $\begin{array}{l}\text { Gas } \\
\text { used. }\end{array}$ & $\begin{array}{c}\text { Effi- } \\
\text { ciency. }\end{array}$ \\
\hline $\begin{array}{l}1 \\
2 \\
3 \\
4 \\
5\end{array}$ & $\begin{array}{c}\text { Ft. } 3 / \mathrm{hr} . \\
11.94 \\
17.27 \\
21.45 \\
25.92 \\
29.20\end{array}$ & $\begin{array}{c}\text { B. t. u. } \text { uft. }^{3} \\
495 \\
492 \\
492 \\
492 \\
492\end{array}$ & \begin{tabular}{|c|} 
B. t. u. $/$ hr. \\
5,860 \\
8,500 \\
10,550 \\
12,750 \\
14,370
\end{tabular} & $\begin{array}{c}\text { Inch. } \\
0.31 \\
.37 \\
.40 \\
.48 \\
.50\end{array}$ & $\begin{array}{c}\text { Inches. } \\
0.64 \\
.70 \\
.85 \\
1.40 \\
1.50\end{array}$ & $\begin{array}{c}\text { Minutes. } \\
15.22 \\
10.32 \\
8.23 \\
6.98 \\
6.44\end{array}$ & $\begin{array}{l}\text { Feet. } \\
3.03 \\
3.00 \\
2.98 \\
3.02 \\
3.14\end{array}$ & $\begin{array}{c}\text { Per cent. } \\
36.7 \\
37.3 \\
37.5 \\
37.1 \\
35.5\end{array}$ \\
\hline
\end{tabular}

\section{TESTS OF " 450 " B. T. U. COXE-OVEN GAS.}

(a) BURNER NO. 1.

With coke-oven gas it was found that the same orifice and airshutter adjustment as made for the city gas was correct for good adjustment. The fact that no readjustment was necessary may be accounted for by the increase in the rate of gas consumption (due to the lower specific gravity) compensating for the drop in heating value. In other words, the hourly rate of B. t. u. supplied to the burner changed but little and the momentum of the gas (which governs the primary air injection) remained approximately the same with the result that the appearance of the flame was not visibily altered. 
The average analysis of the gas used in this test is given in Table 4. Table 5 and Figures I4 and I5 require no detailed explanation for the reader familiar with the preceding discussion.

The adjustment of the air shutter of Burner No. I for the " 450 " B. t. u. coke-oven gas was such as to give an air opening approximately 20 per cent of the area of the air inlet.

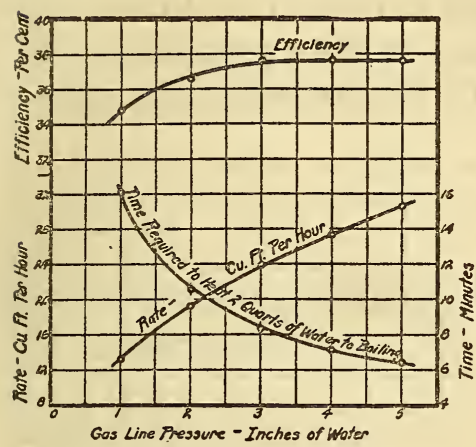

FIG. I4.-Curves showing efficiency, time required, and cubic feet of gas used to heat 2 quarts of water to boiling with coke-oven gas of 447 B. $t$. $u$. and burner No. $I$.

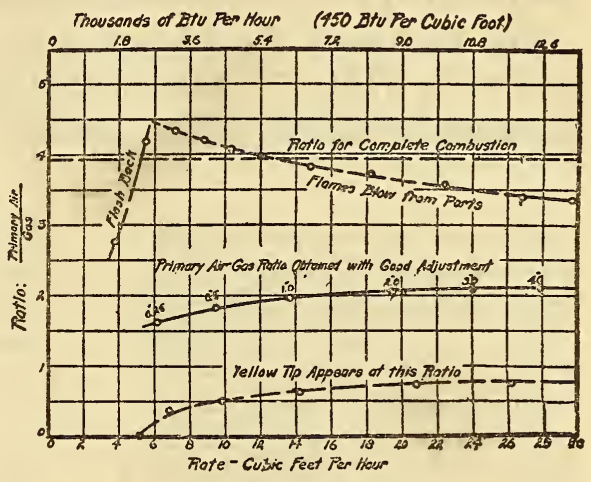

FIG. I5.-Primary air-gas ratio obtained with coke-oven gas of 447 B. t. u. and burner No.I at the different conditions of operation.

Specific gravity of gas, 0.55 .

TABLE 4.-Average Analysis of " 450 " B. t. u. Coke-Oven Gas as Received from Sparrows Point, Md.

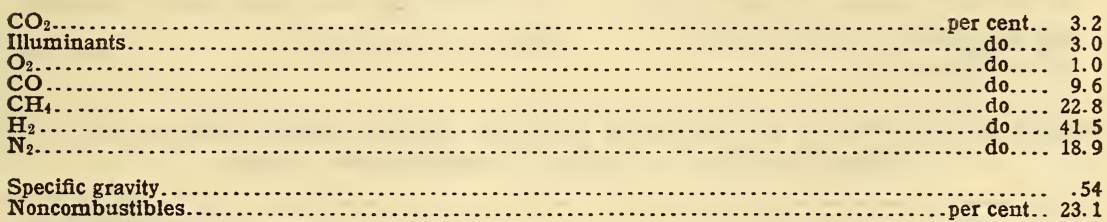

TABLE 5.-“450" B. t. u. Coke-Oven Gas, 0.55 Specific Gravity-Burner No. 1, 48 Ports, No. 40 Drill-Utensil $13 / 8$ Inches from Burner.

\begin{tabular}{|c|c|c|c|c|c|c|c|c|}
\hline $\begin{array}{c}\text { Pressure in } \\
\text { inches } \\
\text { of water. }\end{array}$ & Gas rate. & $\begin{array}{l}\text { Heating } \\
\text { value. }\end{array}$ & $\begin{array}{c}\text { Quantity of } \\
\text { heat } \\
\text { supplied. }\end{array}$ & $\begin{array}{c}\text { Cone } \\
\text { height. }\end{array}$ & $\begin{array}{l}\text { Flame } \\
\text { height. }\end{array}$ & $\begin{array}{c}\text { Time } \\
\text { required } \\
\text { to heat } \\
2 \text { quarts of } \\
\text { water from } \\
80 \text { to } 212^{\circ} \mathrm{F} \text {. }\end{array}$ & $\begin{array}{c}\text { Gas } \\
\text { used. }\end{array}$ & $\underset{\text { ciency. }}{\text { Effi- }}$ \\
\hline $\begin{array}{l}1 \\
2 \\
3 \\
4 \\
5\end{array}$ & $\begin{array}{l}\text { Ft. } / \text { hr. }^{3} \\
13.25 \\
19.11 \\
23.80 \\
27.25 \\
30.50\end{array}$ & $\begin{array}{c}\text { B. t. u./ft. }{ }^{3} \\
447 \\
447 \\
447 \\
447 \\
447\end{array}$ & $\begin{array}{c}\text { B. t. u./hr. } \\
\mathbf{5}, 930 \\
8,520 \\
10,650 \\
12,180 \\
13,640\end{array}$ & $\begin{array}{c}\text { Inch. } \\
0.27 \\
.35 \\
.43 \\
.48 \\
.50\end{array}$ & $\begin{array}{c}\text { Inches. } \\
0.65 \\
.80 \\
.93 \\
1.12 \\
1.32\end{array}$ & $\begin{array}{c}\text { Minutes. } \\
16.14 \\
10.54 \\
8.34 \\
7.21 \\
6.43\end{array}$ & $\begin{array}{l}\text { Feet. }{ }^{3} \\
3.54 \\
3.36 \\
3.27 \\
3.27 \\
3.27\end{array}$ & $\begin{array}{c}\text { Per cent. } \\
34.8 \\
36.7 \\
37.6 \\
37.6 \\
37.6\end{array}$ \\
\hline
\end{tabular}


(b) BURNER NO. 2.

The same orifice and air-shutter adjustment of this burner as used in the test of city gas was also correct for coke-oven gas of this heating value. The reason for this is explained in the discussion of the Burner No. I when operated with coke-oven gas. Although the air shutter was completely closed, the burner received the required primary air through the openings of the loose fittings.

The analysis of the coke-oven gas used in the tests of this burner is given in Table 4. Table 6 and Figures 16 and 17 should be selfexplanatory to the reader familiar with the preceding discussion.

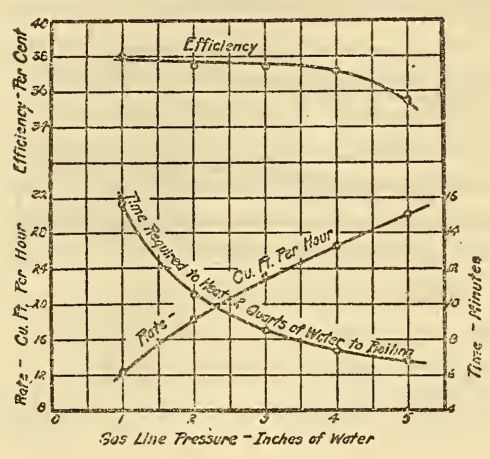

FIG. I6.-Curves showing efficiency, time required, and cubic feet of gas used to heat 2 quarts of water to boiling with coke-oven gas of 453 B. $t$. u. and burner No. 2.

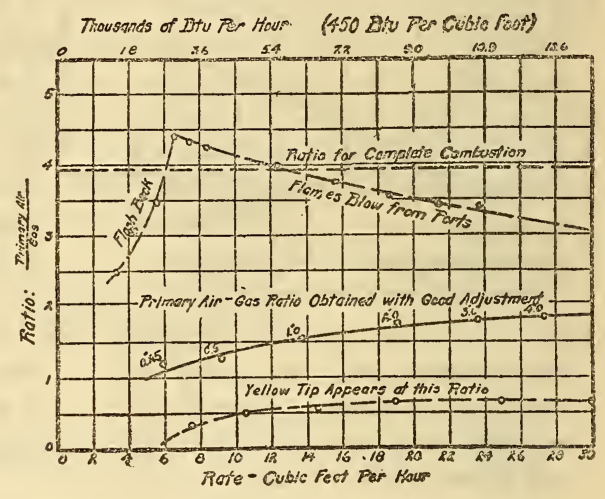

FIG. I7.-Primary air-gas ratio obtained with coke-oven gas of 447 B. $t$. $u$. and burner No. 2 at the different conditions of operation. Specific gravity of gas, 0.55 .

TABLE 6.- "450" B. t. u. Coke-Oven Gas, 0.54. Specific Gravity-Burner No. 2, 44 Ports, No. 40 Drill-Utensil $13 / 8$ Inches from Burner.

\begin{tabular}{|c|c|c|c|c|c|c|c|c|}
\hline $\begin{array}{l}\text { Pressure in } \\
\text { inches } \\
\text { of water. }\end{array}$ & Gas rate. & $\begin{array}{l}\text { Heating } \\
\text { value. }\end{array}$ & $\begin{array}{c}\text { Quantity of } \\
\text { heat } \\
\text { supplied. }\end{array}$ & $\begin{array}{c}\text { Cone } \\
\text { height. }\end{array}$ & $\begin{array}{l}\text { Flame } \\
\text { height. }\end{array}$ & $\begin{array}{c}\text { Time } \\
\text { required } \\
\text { to heat } \\
2 \text { quarts of } \\
\text { water from } \\
80 \text { to } 212^{\circ} \mathrm{F} .\end{array}$ & $\begin{array}{c}\text { Gas } \\
\text { used. }\end{array}$ & $\begin{array}{l}\text { Effi- } \\
\text { ciency. }\end{array}$ \\
\hline $\begin{array}{l}1 \\
2 \\
3 \\
4 \\
5\end{array}$ & $\begin{array}{c}\text { Ft. } 3 / \mathrm{hr} . \\
12.18 \\
18.44 \\
22.90 \\
26.62 \\
30.20\end{array}$ & $\begin{array}{c}\text { B.t. u. } \text { u. }_{\text {ft. }}{ }^{3} \\
453 \\
453 \\
453 \\
453 \\
453\end{array}$ & $\begin{array}{c}\text { B. t. u./hr. } \\
5,530 \\
8,360 \\
10,380 \\
12,070 \\
13,690\end{array}$ & $\begin{array}{c}\text { Inch. } \\
0.30 \\
.38 \\
.45 \\
.50 \\
.53\end{array}$ & $\begin{array}{c}\text { Inches. } \\
0.55 \\
.77 \\
.90 \\
1.07 \\
1.23\end{array}$ & $\begin{array}{c}\text { Minutes. } \\
15.71 \\
10.55 \\
8.48 \\
7.36 \\
6.80\end{array}$ & $\begin{array}{l}\text { Feet. }{ }^{3} \\
3.19 \\
3.23 \\
3.24 \\
3.27 \\
3.42\end{array}$ & $\begin{array}{c}\text { Per cerit. } \\
38.1 \\
37.5 \\
37.4 \\
37.2 \\
3.5 .5\end{array}$ \\
\hline
\end{tabular}

3. TESTS OF “525” B. T. U. COAL GAS.

(a) BURNER NO. 1.

The coal gas used in these tests was obtained from the Philadelphia Gas Works. The gas was received in cylinders compressed to a pressure of approximately I5O atmospheres, which probably 
caused some of the illuminants to condense. It would seem that the average analysis given in Table 7 is, therefore, very similar to what should be expected if the gas were scrubbed for light oils.

To make the good adjustment of this burner it was necessary to have the air shutter about three-fourths open.

The results of the efficiency and operation tests of Burner No. I are given in Table 8 and Figures 18 and I9.

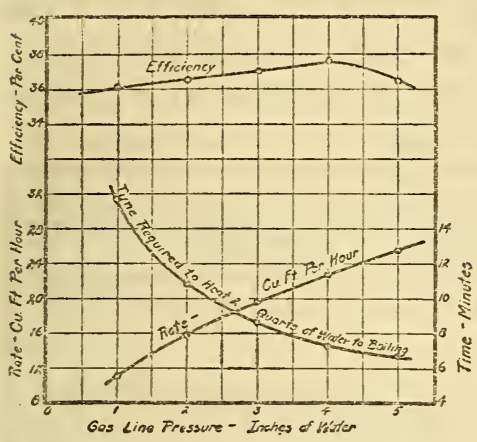

FIG. I8.-Curves shorving efficiency, time required, and cubic feet of gas used to heat 2 quarts of water to boiling with coal gas of 523 B. t. u. and burner No. I.

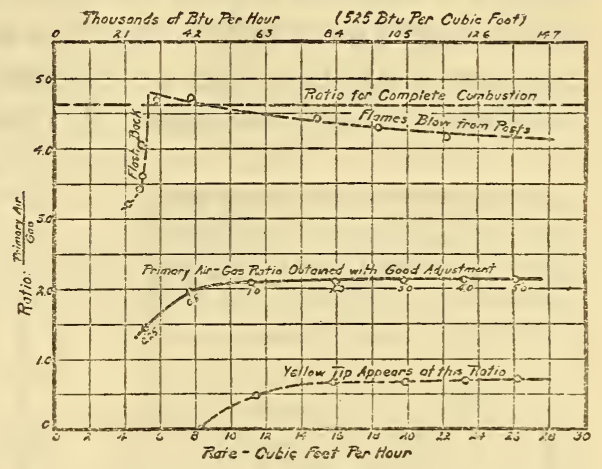

FIIG. I9.-Primary air-gas ratio obtained with coal gas of 523 B.t. u. and burner No. I at the different conditions of operation.

Specific gravity of gas, 0.44 .

TABLE 7.-Average Analysis of " 525 " B. t. u. Coal Gas Received from the Philadelohia Gas Works.

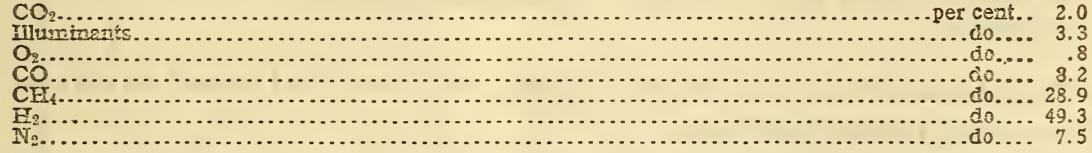

Specific gravity.

TABLE 8.-"525" B. t. u. Coal Gas, 0.444 Specific Grapity-Burner No. 1, 48 Ports, No. 40 Drill-Utensil $13 / 8$ Inches from Burner.

\begin{tabular}{|c|c|c|c|c|c|c|c|c|}
\hline $\begin{array}{l}\text { Pressure in } \\
\text { inches } \\
\text { of water. }\end{array}$ & Gas rate. & $\begin{array}{l}\text { Heating } \\
\text { value. }\end{array}$ & $\begin{array}{c}\text { Quantity of } \\
\text { heat } \\
\text { supplied. }\end{array}$ & $\begin{array}{c}\text { Cone } \\
\text { height. }\end{array}$ & $\begin{array}{l}\text { Flame } \\
\text { height. }\end{array}$ & $\begin{array}{c}\text { Time } \\
\text { required } \\
\text { to heat } \\
2 \text { quarts of } \\
\text { water from } \\
80 \text { to } 212^{\circ} \mathrm{F} \text {. }\end{array}$ & $\begin{array}{c}\text { Gas } \\
\text { used. }\end{array}$ & $\begin{array}{l}\text { Effi- } \\
\text { ciency. }\end{array}$ \\
\hline $\begin{array}{l}1 \\
2 \\
3 \\
4 \\
5\end{array}$ & $\begin{array}{c}\text { Ft. } 3 / \mathrm{hr} . \\
11.09 \\
15.85 \\
19.75 \\
22.78 \\
25.70\end{array}$ & $\begin{array}{c}\text { B.t. 1u./ft. } 3 \\
523 \\
523 \\
523 \\
523 \\
523\end{array}$ & $\begin{array}{c}\text { B. t. u./hr. } \\
5,800 \\
8,290 \\
10,330 \\
11,900 \\
13,440\end{array}$ & $\begin{array}{l}\text { Inch. } \\
0.27 \\
.34 \\
.40 \\
.44 \\
.48\end{array}$ & $\begin{array}{c}\text { Inches. } \\
0.60 \\
.80 \\
1.05 \\
1.20 \\
1.30\end{array}$ & $\begin{array}{c}\text { Mirutes. } \\
15.75 \\
10.87 \\
8.63 \\
7.32 \\
6.74\end{array}$ & $\begin{array}{l}\text { Feet. } \\
2.91 \\
2.88 \\
2.84 \\
2.78 \\
2.89\end{array}$ & $\begin{array}{c}\text { Per cent. } \\
36.1 \\
36.5 \\
37.0 \\
37.7 \\
35.4\end{array}$ \\
\hline
\end{tabular}


(b) BURNER NO. 2.

The air shutter was about one-half open for the good adjustment of Burner No. 2 with this gas. This gas required the largest airshutter opening for the condition of good adjustment of any of the gases tested. This is due to the low specific gravity, which was 0.44 . The heating value of this coal gas is nearly the same as that of the city gas, and the gas rate would be nearly the same to give a uniform B. t. $u$. rate per hour. But the specific gravity of the coal gas is much less than that of city gas, and hence the amount of air that can be injected per cubic foot of gas is less. Therefore, it was necessary to open the air shutter to a greater

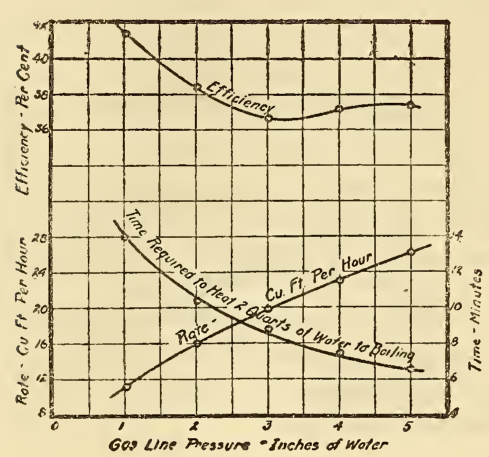

Fig. 20.-Curves showing efficiency, time required, and cubic feet of gas used to heat 2 quarts of water to boiling with coal gas of 524 B. t. u. and burner No. 2.

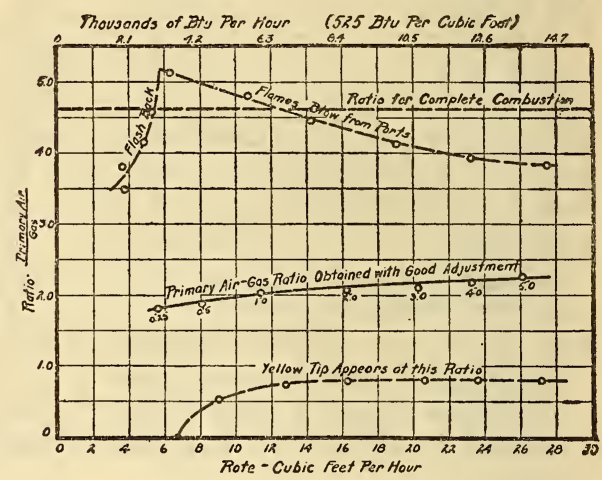

FIG. 21.-Primary air-gas ratio obtained with coal gas of 524 B.t. u. and burner No. 2 at the different conditions of operation.

Specific gravity of gas, 0.44 .

extent in order to draw more primary air into the burner to obtain the same good adjustment.

The average analysis of the " 525 " B. t. u. coal gas is reported in Table 7.

The efficiency and operation tests of this burner are given in Table 9 and Figures 20 and 2I.

TABLE 9.-“525” B. t. u. Coal Gas, 0.444 Specific Gravity-Burner No. 2, 44 Ports, No. 40 Drill-Utensil $13 / 8$ Inches from Burner.

\begin{tabular}{|c|c|c|c|c|c|c|c|c|}
\hline $\begin{array}{l}\text { Pressure in } \\
\text { inches } \\
\text { of water. }\end{array}$ & Gas rate. & $\begin{array}{c}\text { Heating } \\
\text { value. }\end{array}$ & $\begin{array}{c}\text { Quantity of } \\
\text { heat } \\
\text { supplied. }\end{array}$ & $\begin{array}{c}\text { Cone } \\
\text { height. }\end{array}$ & $\begin{array}{l}\text { Flame } \\
\text { height. }\end{array}$ & $\begin{array}{c}\text { Time } \\
\text { required } \\
\text { to heat } \\
2 \text { quarts of } \\
\text { water from } \\
80 \text { to } 212^{\circ} \mathrm{F} .\end{array}$ & $\begin{array}{c}\text { Gas } \\
\text { used. }\end{array}$ & $\begin{array}{c}\text { Eff- } \\
\text { ciency. }\end{array}$ \\
\hline $\begin{array}{l}1 \\
2 \\
3 \\
4 \\
5\end{array}$ & $\begin{array}{l}\text { Ft. }{ }^{3} / \mathrm{hr} \text {. } \\
10.91 \\
15.83 \\
19.73 \\
22.89 \\
26.03\end{array}$ & $\begin{array}{c}\text { B. t. u. } \text {.ft. }^{3} \\
524 \\
524 \\
524 \\
524 \\
524\end{array}$ & $\begin{array}{c}\text { B. t. u./hr. } \\
\mathbf{5}, 720 \\
8,290 \\
10,340 \\
12,000 \\
13,650\end{array}$ & $\begin{array}{c}\text { Inch. } \\
0.32 \\
.37 \\
.42 \\
.50 \\
.53\end{array}$ & $\begin{array}{c}\text { Inches. } \\
0.70 \\
1.00 \\
1.20 \\
1.30 \\
1.50\end{array}$ & $\begin{array}{c}\text { Minutes. } \\
13.94 \\
10.31 \\
8.77 \\
7.41 \\
6.48\end{array}$ & $\begin{array}{l}\text { Feet. } \\
2.53 \\
2.73 \\
2.86 \\
2.82 \\
2.81\end{array}$ & $\begin{array}{c}\text { Per cent. } \\
41.4 \\
38.4 \\
36.7 \\
37.2 \\
37.4\end{array}$ \\
\hline
\end{tabular}


4. TESTS OF “ 300 " B. T, U. WATER GAS.

(a) BURNER NO. 1.

To make the good adjustment of Burner No. I with " 300 " B. t. u. water gas it was necessary to completely close the air shutter and to put a rubber sleeve over the shank of the gas cock to stop the flow of air through the hole in the air shutter. Since " 300 " B. t. u. water gas burns more rapidly than that of higher heating value, and since the ratio of air to gas required for complete combustion is so much less, the good adjustment occurs with a much lower ratio of primary air to gas. The ratio is about o.6. Burner No. I consumed 33.5 feet $^{3}$ of gas at the good adjustment for 3 inches pressure and only required 20 . I feet ${ }^{3}$ of primary air. If one wishes to use " 300 " B. t. u. water gas with this burner, it is necessary to have a tight-fitting air shutter or to reduce the gas pressure in order to reduce the injection of air into the burner.

The average analysis of the " 300 " B. t. u. water gas is given in Table io:

Table I I and Figures 22 and 23 contain the efficiency and operation data obtained with Burner No. I.

Figure 23 is very interesting. Burner No. I could be made to "flash back" at all rates of consumption at which tests were made. This is the only gas that has given such results with this burner.

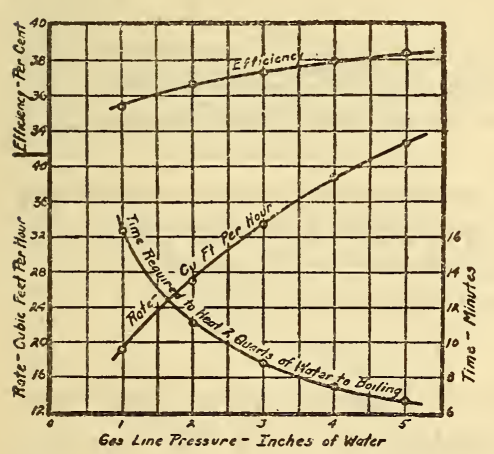

FIG. 22.-Curves showing efficiency, iime required, and cubic feet of gas used to heat 2 quarts of water to boiling with water gas of 299 B. t. u. and bumer No. $I$.

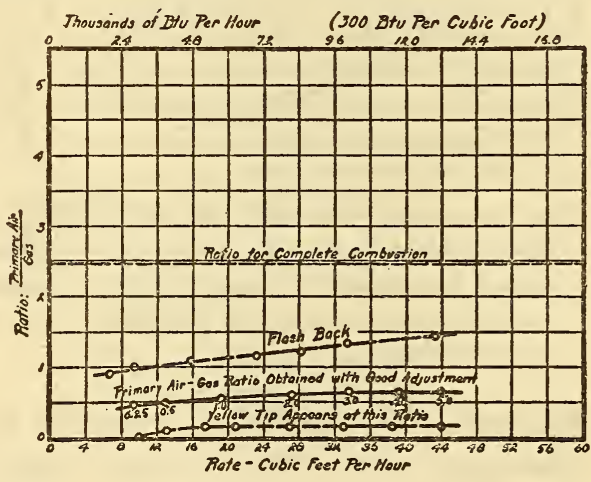

FIG. 23.-Primary air-gas ratio obtained with water gas of 299 B. t. u. and burner No. I at the different conditions of operation.

Specific gravity of gas, 0.574 .

\section{TABLE 10.-Average Anaiysis of " 300 " B. t. u. Water Gas Made at Spring Gardens Plant.}

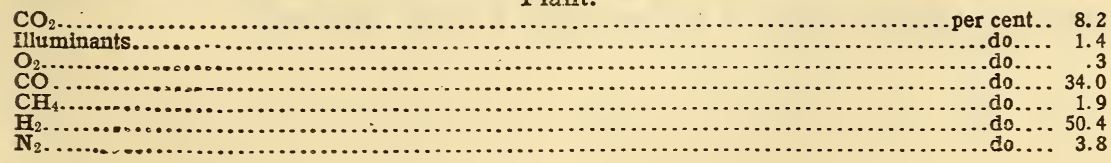


TABLE 11. - "300" B. t. u. Water Gas, 0.574 Specific Gravity-Burner No. 1, 48 Ports, No. 40 Drill-Utensil $13 / 8$ Inches from Burner.

\begin{tabular}{|c|c|c|c|c|c|c|c|c|}
\hline $\begin{array}{c}\text { Pressure in } \\
\text { inches } \\
\text { of water. }\end{array}$ & Gas rate. & $\begin{array}{l}\text { Heating } \\
\text { value. }\end{array}$ & $\begin{array}{c}\text { Quantity of } \\
\text { heat } \\
\text { supplied. }\end{array}$ & $\begin{array}{c}\text { Cone } \\
\text { height. }\end{array}$ & $\begin{array}{l}\text { Flame } \\
\text { height. }\end{array}$ & $\begin{array}{c}\text { Time } \\
\text { required } \\
\text { to heat } \\
2 \text { quarts of } \\
\text { water from } \\
80 \text { to } 212^{\circ} \mathrm{F} .\end{array}$ & $\begin{array}{c}\text { Gas } \\
\text { used. }\end{array}$ & $\begin{array}{l}\text { Eifi- } \\
\text { ciency. }\end{array}$ \\
\hline $\begin{array}{l}1 \\
2 \\
3 \\
4 \\
5\end{array}$ & $\begin{array}{c}\text { Ft. } 3 / \mathrm{hr} . \\
19.16 \\
26.95 \\
33.46 \\
38.90 \\
42.70\end{array}$ & $\begin{array}{c}\text { B. t. u./ft. }{ }^{3} \\
299 \\
299 \\
299 \\
299 \\
299\end{array}$ & \begin{tabular}{|c|} 
B. t. u./hr. \\
5,730 \\
8,060 \\
10,000 \\
11,630 \\
12,780
\end{tabular} & $\begin{array}{c}\text { Inch. } \\
0.20 \\
.25 \\
.28 \\
.32 \\
.35\end{array}$ & $\begin{array}{c}\text { Inches. } \\
0.50 \\
.75 \\
1.00 \\
1.10 \\
1.25\end{array}$ & $\begin{array}{c}\text { Minutes. } \\
16.29 \\
11.17 \\
8.85 \\
7.48 \\
6.75\end{array}$ & $\begin{array}{c}\text { Feet. }^{3} \\
5.20 \\
5.02 \\
4.94 \\
4.85 \\
4.80\end{array}$ & $\begin{array}{c}\text { Per cent. } \\
35.4 \\
36.7 \\
37.3 \\
38.0 \\
38.4\end{array}$ \\
\hline
\end{tabular}

(b) BURNER NO. 2.

The good adjustment of Burner No. 2 for " 300 " B. t. u. water gas was made by closing the opening between the air mixer and the mixing tube with asbestos and by inserting a sheet of copper

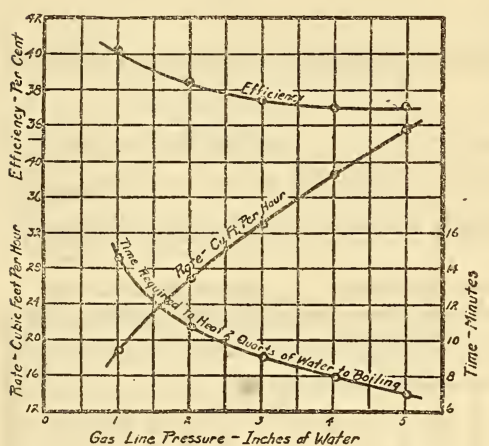

FIG. 24.-Curves showing efficiency, time required, and cubic feet of gas used to heat 2 quarts of water to boiling with water gas of 297 B.t. u. and burner No. 2.

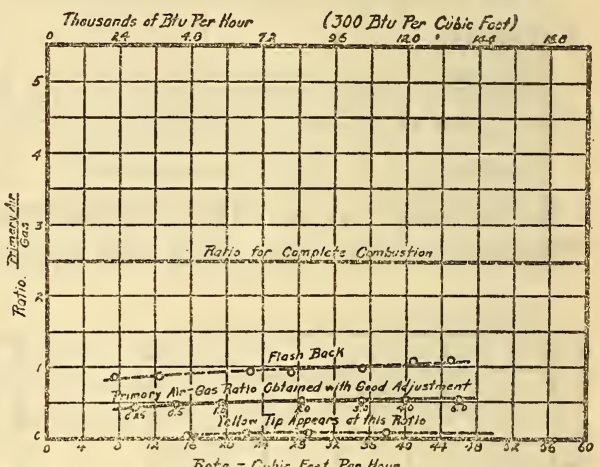

FIG. 25.-Primary air-gas ratio obtained with water gas of 300 B. t. u. and burner No. 2 at the different conditions of operation.

Specific gravity of gas, 0.566 .

between the air-shutter cap and the air mixer. When this was done practically no air could enter the burner. All the required air for the good adjustment entered the burner through a hole about three-sixteenth inch diameter made in the sheet of copper.

The average analysis of the " 300 " B. t. u. water gas is given in Table Io.

Table $\mathrm{r}_{2}$ and Figures 24 and 25 give the efficiency and complete operation data of burner No. 2 with this gas. 
TABLE 12._" $300 "$ B. t. u. Water Gas, 0.566 Specific Gravity-Burner No. 2, 44 Ports, No. 40 Drill-Utensil $13 / 8$ Inches from Burner.

\begin{tabular}{|c|c|c|c|c|c|c|c|c|}
\hline $\begin{array}{c}\text { Pressure in } \\
\text { inches } \\
\text { of water. }\end{array}$ & Gas rate. & $\begin{array}{l}\text { Heating } \\
\text { value. }\end{array}$ & $\begin{array}{c}\text { Quantity of } \\
\text { heat } \\
\text { supplied. }\end{array}$ & $\begin{array}{l}\text { Cone } \\
\text { height. }\end{array}$ & $\begin{array}{l}\text { Flame } \\
\text { height. }\end{array}$ & $\begin{array}{c}\text { Time } \\
\text { required } \\
\text { to heat } \\
2 \text { quarts of } \\
\text { water from } \\
80 \text { to } 212^{\circ} \mathrm{F} \text {. }\end{array}$ & $\begin{array}{l}\text { Gas } \\
\text { used. }\end{array}$ & $\begin{array}{c}\text { Effi- } \\
\text { ciency. }\end{array}$ \\
\hline $\begin{array}{l}1 \\
2 \\
3 \\
4 \\
5\end{array}$ & $\begin{array}{c}\text { Ft. } 3 / \mathrm{hr} \text {. } \\
18.82 \\
26.96 \\
32.89 \\
38.36 \\
43.35\end{array}$ & $\begin{array}{c}\text { B.t.u. } \text { ft. }^{3} \\
297 \\
297 \\
297 \\
297 \\
297\end{array}$ & $\begin{array}{c}\text { B. t. u. /hr. } \\
5,590 \\
8,000 \\
9,740 \\
11,390 \\
12,880\end{array}$ & $\begin{array}{c}\text { Inch. } \\
0.20 \\
.25 \\
.28 \\
.32 \\
.35\end{array}$ & $\begin{array}{c}\text { Inches. } \\
0.55 \\
.75 \\
1.00 \\
1.25 \\
1.40\end{array}$ & $\begin{array}{c}\text { Minutes. } \\
14.65 \\
10.69 \\
9.02 \\
7.91 \\
6.90\end{array}$ & $\begin{array}{l}\text { Feet. } \\
4.59 \\
4.80 \\
4.96 \\
5.04 \\
5.05\end{array}$ & $\begin{array}{c}\text { Per cent. } \\
40.3 \\
38.5 \\
37.5 \\
37.0 \\
37.1\end{array}$ \\
\hline
\end{tabular}

5. TESTS OF “ 350 ” B. T. U. WATER GAS.

(a) BURNER NO. 1.

With the "350" B. t. u. Water gas it was necessary to have the air shutter closed. Sufficient primary air for good adjustment entered through the opening around the shank of the gas cock and a small opening that was not covered by the cap of the air shutter.

The average analysis of the " 350 " B. t. u. water gas is given in Table I3.

The efficiency and operation data are found in Table I4 and Figures 26 and 27.

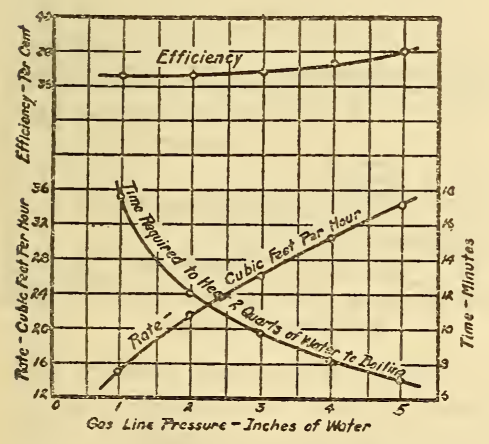

FIG. 26.-Curves showing efficiency, time required, and cubic feet of gas used to heat 2 quarts of water to boiling with water gas of 356 B.t. u. and burner No. I.

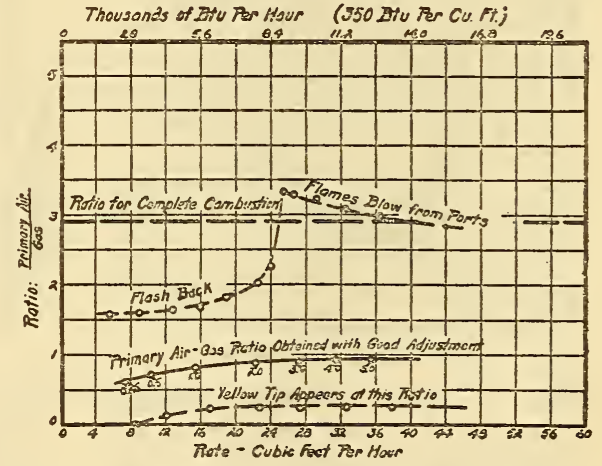

IIIG. 27.-Primary air-gas ratio obtained with water gas of 359 B.t. u. and burner No. I at the different conditions of operation.

Specific gravity of gas, $0.58_{3}$.

TABLE 13.-Average Analysis of " 350 " B. t. w. Water Gas Made at Spring Gardens Plant.

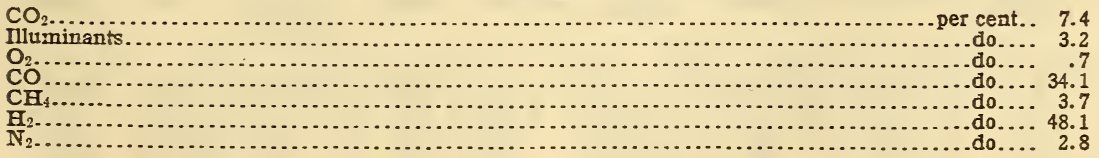

Specific gravity 
TABLE 14.- " $350 "$ B. t. u. Water Gas, 0.58 Specific Gravity-Burner No. 1, 48 Ports, No. 40 Drill-Utensil 1 3/8 Inches from Burner.

\begin{tabular}{|c|c|c|c|c|c|c|c|c|}
\hline $\begin{array}{c}\text { Pressure in } \\
\text { inches } \\
\text { of water. }\end{array}$ & Gas rate. & $\begin{array}{l}\text { Heating } \\
\text { value. }\end{array}$ & $\begin{array}{l}\text { Quantity of } \\
\text { heat } \\
\text { supplied. }\end{array}$ & $\begin{array}{c}\text { Cone } \\
\text { height. }\end{array}$ & $\begin{array}{l}\text { Flame } \\
\text { height. }\end{array}$ & $\begin{array}{c}\text { Time } \\
\text { required } \\
\text { to heat } \\
2 \text { quarts of } \\
\text { water from } \\
80 \text { to } 212^{\circ} \mathrm{F} \text {. }\end{array}$ & $\begin{array}{c}\text { Gas } \\
\text { used. }\end{array}$ & $\begin{array}{c}\text { Effi- } \\
\text { ciency. }\end{array}$ \\
\hline $\begin{array}{l}1 \\
2 \\
3 \\
4 \\
5\end{array}$ & $\begin{array}{c}\text { Ft. } 3 / \mathrm{hr} . \\
14.57 \\
21.34 \\
26.00 \\
30.40 \\
34.33\end{array}$ & $\begin{array}{c}\text { B. t. u./ft. }{ }^{3} \\
356 \\
356 \\
356 \\
356 \\
356\end{array}$ & $\begin{array}{c}\text { B. t. u./hr. } \\
5,190 \\
7,600 \\
9,260 \\
10,820 \\
12,230\end{array}$ & $\begin{array}{c}\text { Inch. } \\
0.22 \\
.27 \\
.30 \\
.35 \\
.40\end{array}$ & $\begin{array}{c}\text { Inches. } \\
0.55 \\
.77 \\
1.00 \\
1.20 \\
1.35\end{array}$ & $\begin{array}{c}\text { Minutes. } \\
17.47 \\
11.92 \\
9.72 \\
8.18 \\
7.11\end{array}$ & $\begin{array}{l}\text { Feet. }^{3} \\
4.25 \\
4.24 \\
4.21 \\
4.15 \\
4.07\end{array}$ & $\begin{array}{c}\text { Per cent. } \\
36.4 \\
36.5 \\
36.7 \\
37.3 \\
38.0\end{array}$ \\
\hline
\end{tabular}

(b) BURNER NO. 2.

All of the primary air required for the good adjustment of Burner No. 2 with " 350 " B. t. u. water gas entered through the loose-fitting cap. The slot opening for the air-shutter screw was covered with a piece of sheet copper and the opening where the mixing tube enters the air mixer was closed with asbestos.

The average analysis of the " 350 " B. t. u. water gas is given in Table 13 .

The efficiency and operation data of burner No. 2 are given in Table 15 and Figures 28 and 29.

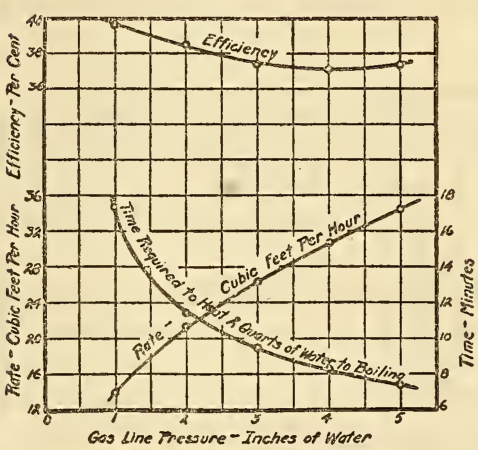

FIG. 28.-Curves showing efficiency, time required, and cubic feet of gas used to heat 2 quarts of water to boiling with water gas of 352 B. t. u. and burner No. 2.

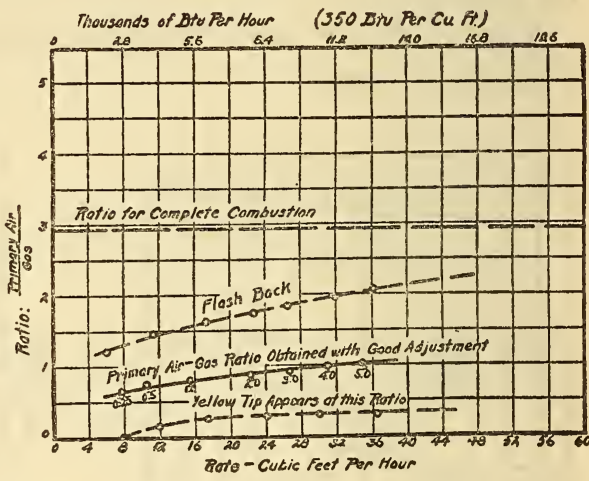

FIG. 29.-Primary air-gas ratio obtained with water gas of 352 B.t. $u$. and burner No. 2 at the different conditions of operation.

Specific gravity of gas, 0.576 .

TABLE 15.-“350" B.t. u. Water Gas, 0.58 Specific Gravity-Burner No. 2, 44 Ports, No. 40 Drill-Utensil $13 / 8$ Inches from Burner.

\begin{tabular}{|c|c|c|c|c|c|c|c|c|}
\hline $\begin{array}{c}\text { Pressure in } \\
\text { inches } \\
\text { of water. }\end{array}$ & Gas rate. & $\begin{array}{l}\text { Heating } \\
\text { value. }\end{array}$ & $\begin{array}{c}\text { Quantity of } \\
\text { heat } \\
\text { supplied. }\end{array}$ & $\begin{array}{c}\text { Cone } \\
\text { height. }\end{array}$ & $\begin{array}{l}\text { Flame } \\
\text { height. }\end{array}$ & $\begin{array}{c}\text { Time } \\
\text { required } \\
\text { to heat } \\
2 \text { quarts of } \\
\text { water from } \\
80 \text { to } 212^{\circ} \mathrm{F} \text {. }\end{array}$ & $\begin{array}{c}\text { Gas } \\
\text { used. }\end{array}$ & $\begin{array}{c}\text { Effi- } \\
\text { ciency. }\end{array}$ \\
\hline $\begin{array}{l}1 \\
2 \\
3 \\
4 \\
5\end{array}$ & $\begin{array}{c}\text { Ft. } 3 / \text { hr. } \\
13.72 \\
21.33 \\
26.04 \\
30.55 \\
34.46\end{array}$ & $\begin{array}{c}\text { B. t. u. } \text { fit. }^{3} \\
352 \\
352 \\
352 \\
352 \\
352\end{array}$ & $\begin{array}{c}\text { B. t. u./hr. } \\
4,830 \\
7,510 \\
9,170 \\
10,750 \\
12,130\end{array}$ & $\begin{array}{r}\text { Inch. } \\
0.25 \\
.27 \\
.30 \\
.33 \\
.36\end{array}$ & $\begin{array}{c}\text { Inches. } \\
0.60 \\
.80 \\
1.00 \\
1.15 \\
1.35\end{array}$ & $\begin{array}{c}\text { Minutes. } \\
17.29 \\
11.35 \\
9.60 \\
8.29 \\
7.29\end{array}$ & $\begin{array}{l}\text { Feet. } \\
3.95 \\
4.04 \\
4.18 \\
4.22 \\
4.18\end{array}$ & $\begin{array}{c}\text { Per cent. } \\
39.6 \\
38.6 \\
37.4 \\
37.2 \\
37.4\end{array}$ \\
\hline
\end{tabular}


6. TESTS OF “ 400 " B. T. U. WATER GAS.

(a) BURNER NO. 1.

To make the good adjustment with this heating value the air shutter was almost closed. The air opening was between 2 and 3 per cent of the maximum.

The average analysis of the " 400 " B. t. u. water gas is given in Table 16.

Table $\mathrm{I} 7$ and Figures 30 and $3^{\mathrm{I}}$ give the efficiency and complete operation data obtained with this burner and " 400 " B. t. u. water gas.

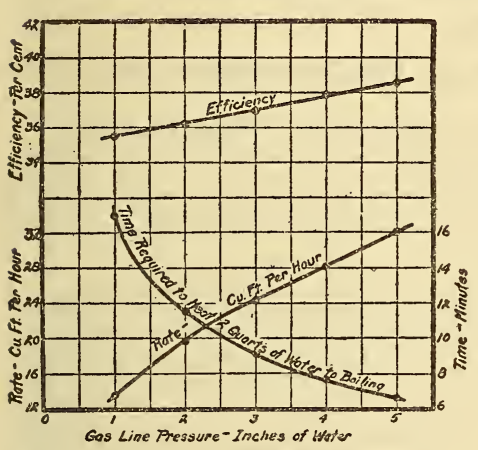

FIG. 30.-Curves showing efficiency, time required, and cubic feet of gas used to heat 2 quarts of water to boiling with water gas of 399 B. $t$. u. and burner No. I.

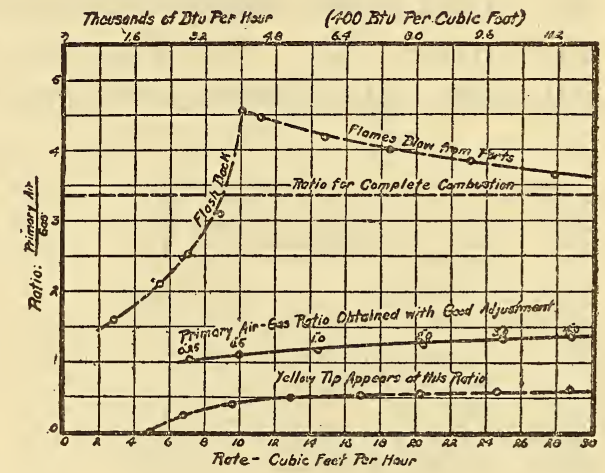

FIG. 31.-Primary air-gas ratio obtained with water gas of 406 B.t. u. and burner No. I at the different conditions of operation.

Specific gravity of gas, 0.585 .

TABLE 16.-Average Analysis of " 400 " B. t. u. Water Gas Made at Spring Gardens Plant.

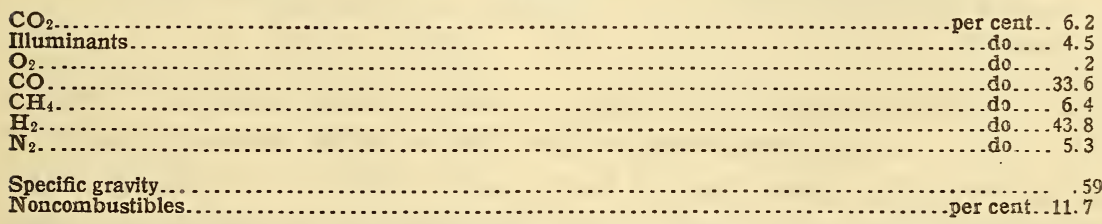

TABLE 17.- “400” B. t. u. Water Gas, 0.595 Specific Gravity-Burner No. 1, 48 Ports, No. 40 Drill-Utensil $13 / 8$ Inches from Burner.

\begin{tabular}{|c|c|c|c|c|c|c|c|c|}
\hline $\begin{array}{c}\text { Pressure in } \\
\text { inches } \\
\text { of water. }\end{array}$ & Gas rate. & $\begin{array}{l}\text { Heating } \\
\text { value. }\end{array}$ & $\begin{array}{c}\text { Quantity of } \\
\text { heat } \\
\text { supplied. }\end{array}$ & $\begin{array}{c}\text { Cone } \\
\text { height. }\end{array}$ & $\begin{array}{l}\text { Flame } \\
\text { height. }\end{array}$ & $\begin{array}{c}\text { Time } \\
\text { required } \\
\text { to heat } \\
2 \text { quarts of } \\
\text { water from } \\
80 \text { to } 212^{\circ} \mathrm{F} \text {. }\end{array}$ & $\begin{array}{c}\text { Gas } \\
\text { used. }\end{array}$ & $\begin{array}{l}\text { Effi- } \\
\text { ciency. }\end{array}$ \\
\hline $\begin{array}{l}1 \\
2 \\
2 \\
4 \\
5\end{array}$ & $\begin{array}{c}\text { Ft. } 3 / \mathrm{hr} . \\
13.60 \\
19.71 \\
24.42 \\
28.21 \\
32.17\end{array}$ & \begin{tabular}{|c} 
B. t. u. ut $^{8}$. $^{-}$ \\
399 \\
399 \\
399 \\
399 \\
399
\end{tabular} & $\begin{array}{c}\text { B. t. u./hr. } \\
5,420 \\
7,870 \\
9,740 \\
11,260 \\
12,840\end{array}$ & $\begin{array}{c}\text { Inch. } \\
0.25 \\
.28 \\
.32 \\
.36 \\
.40\end{array}$ & $\begin{array}{c}\text { Inches. } \\
0.54 \\
.78 \\
.95 \\
1.15 \\
1.34\end{array}$ & $\begin{array}{c}\text { Minutes. } \\
17.01 \\
11.61 \\
9.19 \\
7.75 \\
6.64\end{array}$ & $\begin{array}{l}\text { Feet. }^{3} \\
3.86 \\
3.81 \\
3.74 \\
3.65 \\
3.57\end{array}$ & $\begin{array}{c}\text { Per cent. } \\
35.6 \\
36.2 \\
37.0 \\
37.9 \\
38.6\end{array}$ \\
\hline
\end{tabular}


(b) BURNER NO. 2.

This burner can not be operated with this heating value gas when adjusted at a pressure of 3 inches, even with the air shutter completely closed, unless much of the remaining primary air opening is closed. To obtain a good adjustment asbestos was used to completely close the opening where the mixing tube enters the air mixer and also to close about two-thirds of the slot opening for the air-shutter screw.

Interesting information obtained with this burner is shown by the "flash-back" curve given in Figure 33. It will be noted that the "flash-back" curve is entirely different from that obtained with Burner No. I (see Fig. 3I) and with this same heatingvalue gas. It is known that the size of the ports and the com-

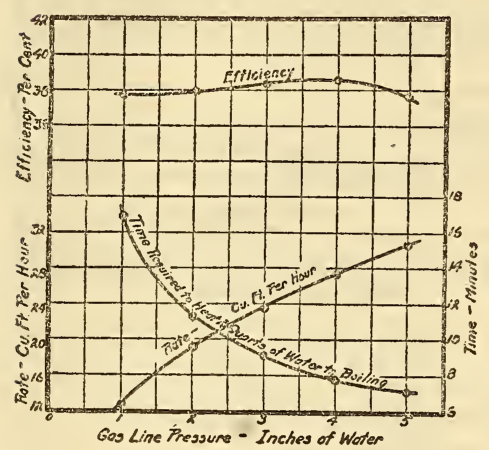

Fig. 32.-Curves showing efficiency, time required, and cubic feet of gas used to heat 2 quarts of water to boiling with water gas of $40 \mathrm{O}$ B. t. u. and burner No. 2.

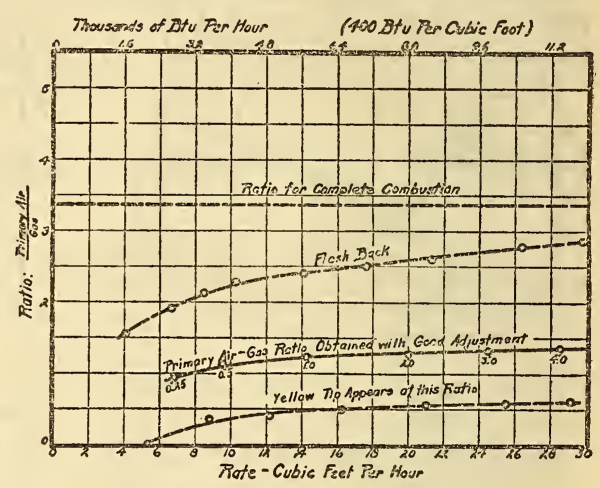

FrG. 33.-Primary air-gas ratio obtained with water gas of 406 B. t. u. and burner No. 2 at the different conditions of operation.

Specific gravity of gas, 0.585 .

position of the gas are factors causing "flash back." Burner No. 2 has several ports larger than No. 40 drill, through which it is believed the flame flashed back under different conditions than those at which the "flash back" would have occurred if the ports were all No. 40 drill size. It would seem that gases of lower heating value tend to disclose such defects. However, these factors do not affect the operation of the burner when properly adjusted.

The average analysis of the " 400 " B. t. u. water gas is given in Table 16.

Table 18 and Figures 32 and 33 contain the efficiency and complete operation data obtained with this burner and " 400 " B. t. u. water gas. 
TABLE 18.-“400" B. t. u. Water Gas, 0.595 Specific Gravity-Burner No. 2, 44 Ports, No. 40 Drill-Utensil $13 / 8$ Inches from Burner.

\begin{tabular}{|c|c|c|c|c|c|c|c|c|}
\hline $\begin{array}{l}\text { Pressure in } \\
\text { inches } \\
\text { of water. }\end{array}$ & Gas rate. & $\begin{array}{l}\text { Heating } \\
\text { value. }\end{array}$ & $\begin{array}{c}\text { Quantity of } \\
\text { heat } \\
\text { supplied. }\end{array}$ & $\begin{array}{c}\text { Cone } \\
\text { height. }\end{array}$ & $\begin{array}{l}\text { Flame } \\
\text { height. }\end{array}$ & $\begin{array}{c}\text { Time } \\
\text { required } \\
\text { to heat } \\
2 \text { quarts of } \\
\text { water from } \\
80 \text { to } 212^{\circ} \mathrm{F} .\end{array}$ & $\begin{array}{l}\text { Gas } \\
\text { used. }\end{array}$ & $\begin{array}{c}\text { Effi- } \\
\text { ciency. }\end{array}$ \\
\hline $\begin{array}{l}1 \\
2 \\
3 \\
4 \\
5\end{array}$ & $\begin{array}{c}\text { Ft. }^{3} / \mathrm{hr} . \\
12.85 \\
19.18 \\
23.62 \\
27.54 \\
30.85\end{array}$ & $\begin{array}{c}\text { B.t. u. } \text { ftt. }^{3} \\
401 \\
401 \\
401 \\
401 \\
401\end{array}$ & \begin{tabular}{|c|} 
B. t. u./hr. \\
5,150 \\
7,700 \\
9,470 \\
11,050 \\
12,350
\end{tabular} & $\begin{array}{c}\text { Inch. } \\
0.23 \\
.26 \\
.29 \\
.33 \\
.36\end{array}$ & $\begin{array}{c}\text { Inches. } \\
0.64 \\
.88 \\
.97 \\
1.08 \\
1.25\end{array}$ & $\begin{array}{c}\text { Minutes. } \\
16.98 \\
11.32 \\
9.08 \\
7.76 \\
7.10\end{array}$ & $\begin{array}{l}\text { Feet. } 3 \\
3.64 \\
3.62 \\
3.58 \\
3.56 \\
3.65\end{array}$ & $\begin{array}{c}\text { Per cent. } \\
37.8 \\
38.0 \\
38.4 \\
38.6 \\
37.7\end{array}$ \\
\hline
\end{tabular}

7. TESTS OF "450" B. T. U. WATER GAS.

(a) BURNER NO. 1.

To test water gas of this heating value with Burner No. I the same orifice was used as in the tests of " 500 " B. t. u. city gas and and " 450 " B. t. u. coke-oven gas. At 3 inches pressure less heat units were delivered per hour than with the two above gases, but

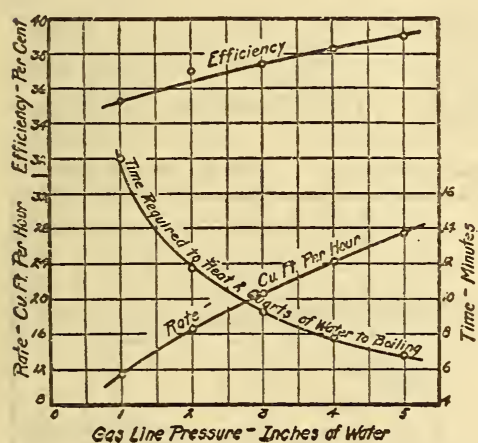

Fig. 34.-Curves showing efficiency, time required, and cubic feet of gas used to heat 2 quarts of water to boil. ing with water gas of 454 B. t. u. and burner No. $I$.

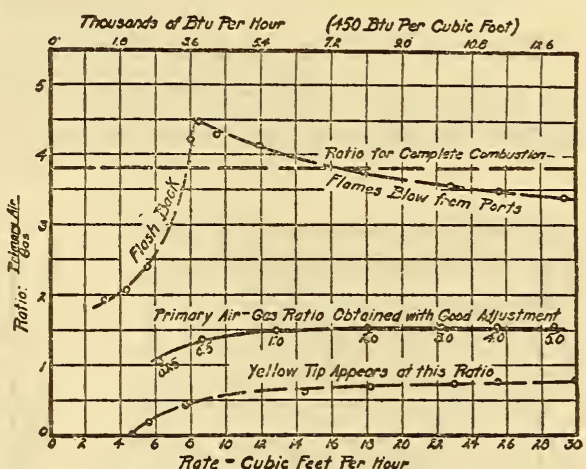

FIG. 35.-Primary air-gas ratio obtained with water gas of 448 B. t. u. and burner No. I at the different conditions of operation.

Specific gravity of gas, $0.6 \mathrm{r} 4$.

it was decided that the burner still received an ample amount. In order to secure a good flame, however, the air shutter had to be closed until it was about 8 per cent open. The reason for the air-shutter readjustment will be discussed in Section VII of this report.

The average analysis of the " 450 " B. t. u. water gas is given in Table I 9.

Table 20 and Figures 34 and 35 give the efficiency and complete operation data obtained with this burner and " 450 " B. t. u. water gas.

$$
110180^{\circ}-22-3
$$


TABLE 19.-Average Analysis of " 450 ” B. t. u. Water Gas Made at Spring Gardens Plant.

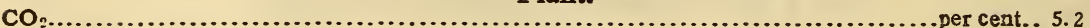

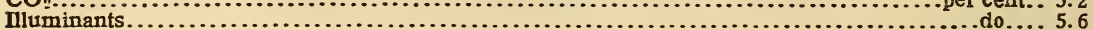

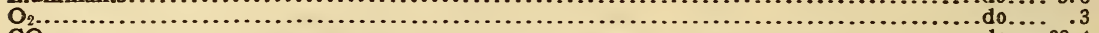

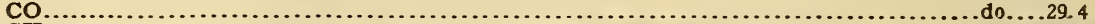

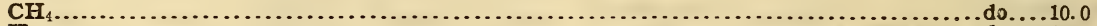

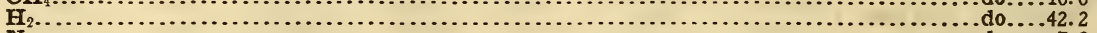

Specific gravity.

.617

Noncombustibles.

per cent..12.8

TABLE 20._" "450" B. t. u. Water Gas, 0.614 Specific Gravity-Burner No. 1, 48 Ports, No. 40 Drill-Utensil $13 / 8$ Inches from Burner.

\begin{tabular}{|c|c|c|c|c|c|c|c|c|}
\hline $\begin{array}{l}\text { Pressure in } \\
\text { inches } \\
\text { of water. }\end{array}$ & Gas rate. & $\begin{array}{l}\text { Heating } \\
\text { value. }\end{array}$ & $\begin{array}{c}\text { Quantity of } \\
\text { heat } \\
\text { supplied. }\end{array}$ & $\begin{array}{c}\text { Cone } \\
\text { height. }\end{array}$ & $\begin{array}{l}\text { Flame } \\
\text { height. }\end{array}$ & $\begin{array}{c}\text { Time } \\
\text { required } \\
\text { to heat } \\
2 \text { quarts of } \\
\text { water from } \\
80 \text { to } 212^{\circ} \mathrm{F} \text {. }\end{array}$ & $\begin{array}{c}\text { Gas } \\
\text { used. }\end{array}$ & $\begin{array}{c}\text { Effi- } \\
\text { ciency. }\end{array}$ \\
\hline $\begin{array}{l}1 \\
2 \\
3 \\
4 \\
5\end{array}$ & $\begin{array}{l}\text { Ft. }{ }^{3} / \mathrm{hr} . \\
11.44 \\
16.71 \\
20.75 \\
24.30 \\
27.45\end{array}$ & $\begin{array}{c}\text { B.t. u./ft. } 8 \\
454 \\
454 \\
454 \\
454 \\
454\end{array}$ & $\begin{array}{c}\text { B. t. u./hr. } \\
5,200 \\
7,590 \\
9,420 \\
11,040 \\
12,460\end{array}$ & $\begin{array}{c}\text { Inch. } \\
0.25 \\
.30 \\
.35 \\
.40 \\
.45\end{array}$ & $\begin{array}{c}\text { Inches. } \\
0.55 \\
.78 \\
.90 \\
1.00 \\
1.15\end{array}$ & $\begin{array}{c}\text { Minutes. } \\
18.04 \\
11.73 \\
9.37 \\
7.83 \\
6.80\end{array}$ & $\begin{array}{l}\text { Feet. }^{3} \\
3.44 \\
3.28 \\
3.24 \\
3.17 \\
3.11\end{array}$ & $\begin{array}{c}\text { Per cent. } \\
35.3 \\
37.0 \\
37.4 \\
38.2 \\
39.0\end{array}$ \\
\hline
\end{tabular}

(b) BURNER NO. 2.

The air shutter of this burner was completely closed; the same as with " 450 " coke-oven and " 500 " B. t. u. city gas, which was approximately 33 per cent coke-oven gas. The flame was harder

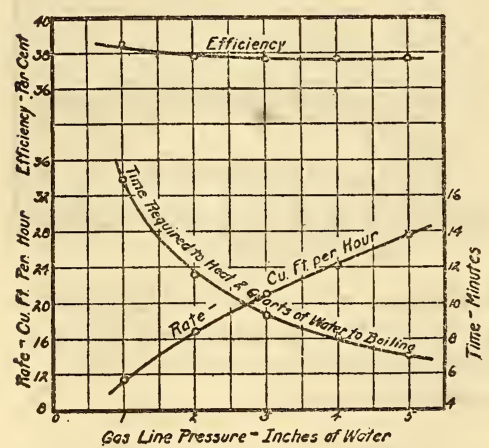

Fig. 36.-Curves showing efficiency, time required, and cubic feet of gas used to heat 2 quarts of water to boiling with water gas of 448 B.t. u. and burner No. 2.

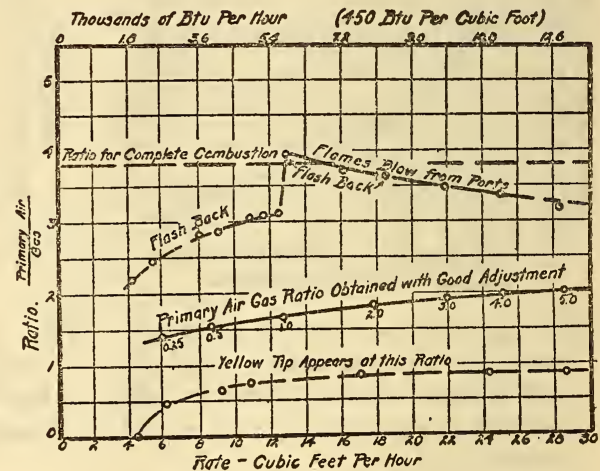

FIG. 37.-Primary air-gas ratio obtained with water gas of 447 B.t. u. and burner No. 2 at the different conditions of operation.

Specific gravity of gas, 0.620 .

than that which we consider to be a good adjustment; but it was impossible to secure the good adjustment without stopping the flow of some of the air that entered the burner through the slot opening for the air-shutter screw or some of that which entered through the loose fitting of the air mixer. It was decided to test the burner without making any further changes, since there was no trouble from flash back when the gas was turned down. 
The analysis of the " 450 " B. t. u. water gas is given in Table 19 . Table $2 \mathrm{I}$ and Figures 36 and 37 give the efficiency and complete operation data with this burner.

TABLE 21.-“450" B. t. u. Water Gas, 0.614 Specific Gravity-Burner No. 2, 44 Ports, No. 40 Drill-Utensil $13 / 8$ Inches from Burner.

\begin{tabular}{|c|c|c|c|c|c|c|c|c|}
\hline $\begin{array}{c}\text { Pressure in } \\
\text { inches } \\
\text { of water. }\end{array}$ & Gas rate. & $\begin{array}{l}\text { Heating } \\
\text { value. }\end{array}$ & $\begin{array}{c}\text { Quantity of } \\
\text { heat } \\
\text { supplied. }\end{array}$ & $\begin{array}{c}\text { Cone } \\
\text { height. }\end{array}$ & $\begin{array}{l}\text { Flame } \\
\text { height. }\end{array}$ & $\begin{array}{c}\text { Time } \\
\text { required } \\
\text { to heat } \\
2 \text { quarts of } \\
\text { water from } \\
80 \text { to } 212^{\circ} \mathrm{F} \text {. }\end{array}$ & $\begin{array}{c}\text { Gas } \\
\text { used. }\end{array}$ & $\begin{array}{l}\text { Effi- } \\
\text { ciency. }\end{array}$ \\
\hline $\begin{array}{l}1 \\
2 \\
3 \\
4 \\
5\end{array}$ & $\begin{array}{c}\text { Ft. }{ }^{3} / \mathrm{hr} . \\
11.31 \\
16.78 \\
21.13 \\
24.12 \\
27.70\end{array}$ & $\begin{array}{c}\text { B. t. u. } \text { fft. }^{3} \\
448 \\
448 \\
448 \\
448 \\
448\end{array}$ & $\begin{array}{c}\text { B. t. u./hr. } \\
5,070 \\
7,520 \\
9,470 \\
10,810 \\
12,400\end{array}$ & $\begin{array}{c}\text { Inch. } \\
0.20 \\
.25 \\
.28 \\
.30 \\
.34\end{array}$ & $\begin{array}{c}\text { Inches. } \\
0.50 \\
.75 \\
.85 \\
.95 \\
1.18\end{array}$ & $\begin{array}{c}\text { Minutes. } \\
16.86 \\
11.60 \\
9.26 \\
8.09 \\
7.06\end{array}$ & $\begin{array}{l}\text { Feet. }^{3} \\
3.18 \\
3.25 \\
3.26 \\
3.26 \\
3.26\end{array}$ & $\begin{array}{c}\text { Per cent. } \\
38.6 \\
37.8 \\
37.7 \\
37.7 \\
37.7\end{array}$ \\
\hline
\end{tabular}

8. TESTS OF “500" B. T. U. WATER GAS.

(a) BURNER NO. 1.

To make good adjustment with " 500 " B. t. u. water gas the air shutter was about i 6 per cent open.

The average analysis of the gas is given in Table 22 .

Table 23 and Figures 38 and 39 give the efficiency and complete operation data obtained with " 500 " B. t. u. water gas.

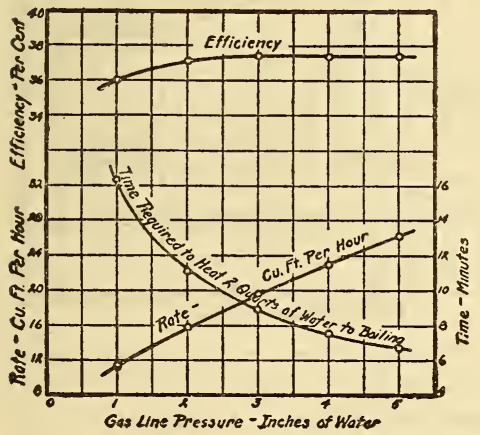

FIG. 38.-Curves showing efficiency, time required, and cubic feet of gas used to heat 2 quarts of water to boiling with water gas of 505 B. t. u. and burner No. I.

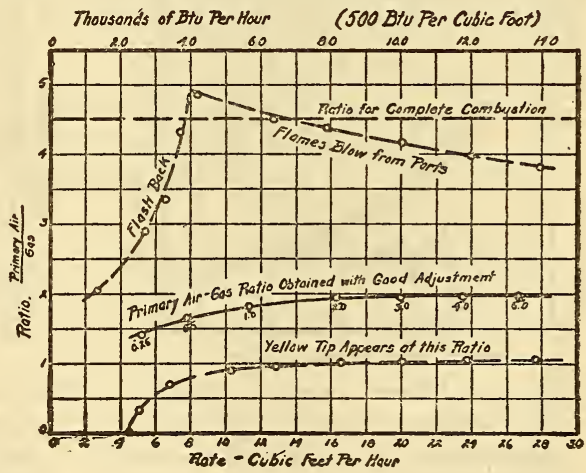

FIG. 39.-Primary air-gas ratio obtained with water gas of $50 I$ B.t. u. and burner No. I at the different conditions of operation.

Specific gravity of gas, 0.633

TABLE 22.-Average Analysis of "500" B. t. u. Water Gas Made at Spring Gardens Plant.

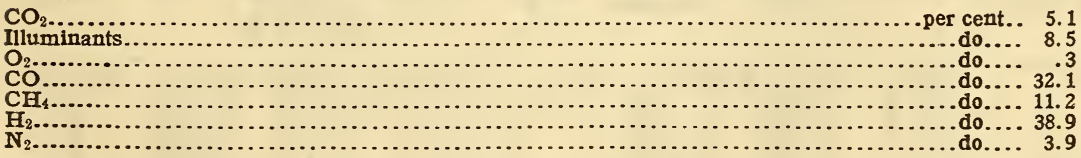

Specific gravity. 
TABLE 23.- "500" B. t. u. Water Gas, 0.634 Specific Gravity--Burner No. 1, 48 Ports, No. 40 Drill-Utensil $13 / 8$ Inches from Burner.

\begin{tabular}{|c|c|c|c|c|c|c|c|c|}
\hline $\begin{array}{l}\text { Pressure in } \\
\text { inches } \\
\text { of water. }\end{array}$ & Gas rate. & $\begin{array}{l}\text { Heating } \\
\text { value. }\end{array}$ & $\begin{array}{c}\text { Quantity of } \\
\text { heat } \\
\text { supplied. }\end{array}$ & $\begin{array}{c}\text { Cone } \\
\text { height. }\end{array}$ & $\begin{array}{l}\text { Flame } \\
\text { height. }\end{array}$ & $\begin{array}{c}\text { Time } \\
\text { required } \\
\text { to heat } \\
2 \text { quarts of } \\
\text { water from } \\
80 \text { to } 212^{\circ} \mathrm{F} \text {. }\end{array}$ & $\begin{array}{c}\text { Gas } \\
\text { used. }\end{array}$ & $\begin{array}{c}\text { Effi- } \\
\text { ciency. }\end{array}$ \\
\hline $\begin{array}{l}1 \\
2 \\
3 \\
4 \\
5\end{array}$ & $\begin{array}{c}\text { Ft. } 3 / \mathbf{h r} . \\
11.11 \\
15.82 \\
19.60 \\
22.86 \\
26.18\end{array}$ & $\begin{array}{c}\text { B. t. u. } \text { ft. }^{3} \\
505 \\
505 \\
505 \\
505 \\
505\end{array}$ & $\begin{array}{c}\text { B. t. u. } / \mathrm{hr} \text {. } \\
5,620 \\
8,000 \\
9,900 \\
11,540 \\
13,230\end{array}$ & $\begin{array}{r}\text { Inch. } \\
0.25 \\
.30 \\
.35 \\
.40 \\
.45\end{array}$ & $\begin{array}{c}\text { Inches. } \\
0.50 \\
.75 \\
.90 \\
1.10 \\
1.30\end{array}$ & $\begin{array}{c}\text { Minutes. } \\
16.33 \\
11.15 \\
8.90 \\
7.67 \\
6.67\end{array}$ & $\begin{array}{l}\text { Feet. }^{3} \\
3.02 \\
2.94 \\
2.91 \\
2.91 \\
2.91\end{array}$ & $\begin{array}{c}\text { Per cent. } \\
36.0 \\
37.1 \\
37.4 \\
37.4 \\
37.5\end{array}$ \\
\hline
\end{tabular}

(b) BURNER NO. 2.

Completely closing the air shutter allowed a little too much air to enter the burner for the good adjustment and a piece of sheet metal was inserted over the slot for the air-shutter screw which practically closed the opening.

The average analysis of the " 500 " B. t. u. water gas is given in Table 22.

Table 24 and Figures 40 and $4 \mathrm{I}$ contain the efficiency and operation data of this burner with " 500 " B. t. u. water gas.

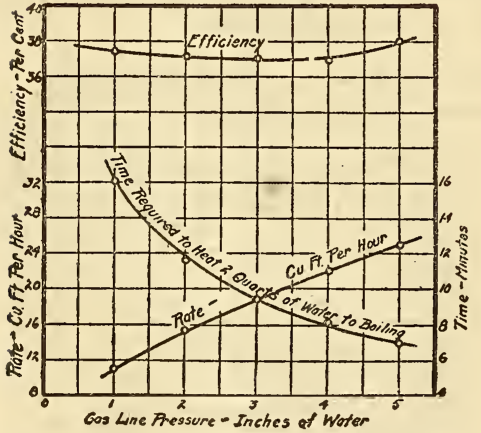

FIG. 40.-Curves showing efficiency, time required, and cubic feet of gas used to heat 2 quarts of water to boiling with water gas of 503 B.t. u. and burner No. 2.

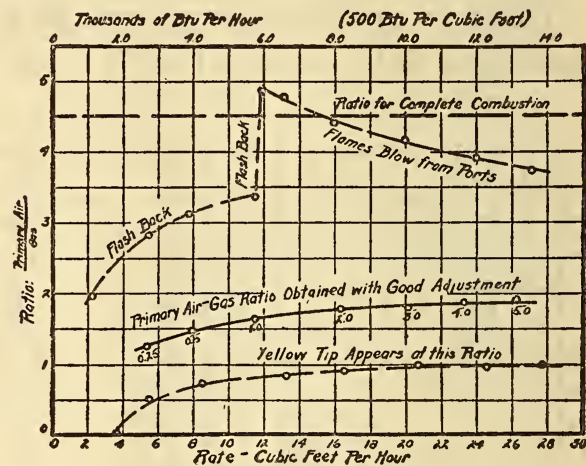

FIG. 4I.-Primary air-gas ratio obtained with water gas of $50 T$ B. $t$. $u$. and burner No. 2 at the different conditions of operation.

Specific gravity of gas, 0.633 .

TABLE 24.- "500" B. t. u. Water Gas, 0.634 Specific Gravity-Burner No. 2, 44 Ports, No. 40 Drill-Utensil $13 / 8$ Inches from Burner.

\begin{tabular}{|c|c|c|c|c|c|c|c|c|}
\hline $\begin{array}{c}\text { Pressure in } \\
\text { inches } \\
\text { of water. }\end{array}$ & Gas rate. & $\begin{array}{l}\text { Heating } \\
\text { value. }\end{array}$ & $\begin{array}{c}\text { Quantity of } \\
\text { heat } \\
\text { supplied. }\end{array}$ & $\begin{array}{c}\text { Cone } \\
\text { height. }\end{array}$ & $\begin{array}{l}\text { Flame } \\
\text { height. }\end{array}$ & $\begin{array}{c}\text { Time } \\
\text { required } \\
\text { to heat } \\
2 \text { quarts of } \\
\text { water from } \\
80 \text { to } 212^{\circ} \mathrm{F} \text {. }\end{array}$ & $\begin{array}{c}\text { Gas } \\
\text { used. }\end{array}$ & $\begin{array}{c}\text { Effi- } \\
\text { ciency. }\end{array}$ \\
\hline $\begin{array}{l}1 \\
2 \\
3 \\
4 \\
5\end{array}$ & $\begin{array}{c}\text { Ft. } 3 / \mathrm{hr} . \\
10.91 \\
15.24 \\
18.95 \\
21.70 \\
24.98\end{array}$ & $\begin{array}{c}\text { B. t. u./ft. }{ }^{3} \\
503 \\
503 \\
503 \\
503 \\
503\end{array}$ & $\begin{array}{c}\text { B. t. u./hr. } \\
5,450 \\
7,660 \\
9,540 \\
10,910 \\
12,560\end{array}$ & $\begin{array}{c}\text { Inch. } \\
0.26 \\
.31 \\
.37 \\
.41 \\
.45\end{array}$ & $\begin{array}{c}\text { Inches. } \\
0.75 \\
.85 \\
1.00 \\
1.10 \\
1.20\end{array}$ & $\begin{array}{c}\text { Minutes. } \\
16.10 \\
11.60 \\
9.45 \\
8.20 \\
6.91\end{array}$ & $\begin{array}{c}\text { Feet. } \\
2.93 \\
2.95 \\
2.96 \\
2.97 \\
2.88\end{array}$ & $\begin{array}{c}\text { Per cent. } \\
37.4 \\
37.1 \\
37.0 \\
36.9 \\
38.0\end{array}$ \\
\hline
\end{tabular}




\title{
9. TESTS OF "550" B. T. U. WATER GAS.
}

\author{
(a) BURNER NO. 1.
}

The air shutter of Burner No. I was about 20 per cent open for the good adjustment with water gas of this heating value. This is the same adjustment that was made for " 450 " B. t. u. coke-oven and " 500 " B. t. u. city gas, but the " 450 " B. t. u. coke-óven gas had a specific gravity of 0.55 , the " 500 " B. t. u. city gas a specific gravity of 0.62 , and the " 550 " water gas a specific gravity of 0.66 .

The average analysis of " 440 " B. t. u. water gas is given in Table 25 .

Table 26 and Figures 42 and 43 give the efficiency and complete operation data of Burner No. I with " 550 " B. t. u. water gas.

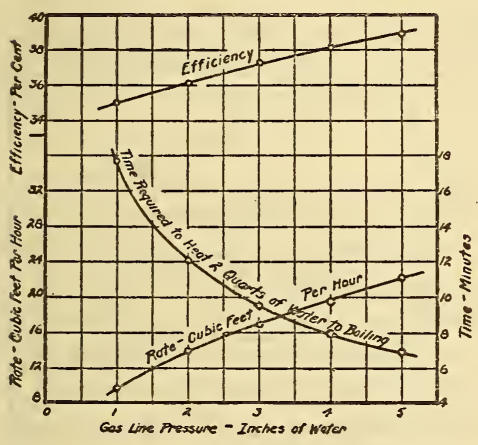

FIG. 42.-Curves showing efficiency, time required, and cubic feet of gas used to heat 2 quarts of water to boiling with water gas of 557 B. t. u. and burner No. I.

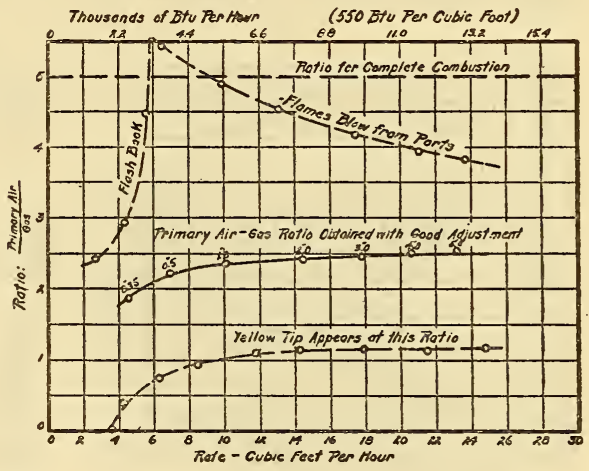

FIG. 43.-Primary air-gas ratio obtained with water gas of 558 B. t. u. and burner No. I at the different conditions of operation.

Specific gravity of gas, 0.662 .

TABLE 2J.-Averas Analysis of "550" B. t. u. Water Gas Made at Spring Gardens Plant.

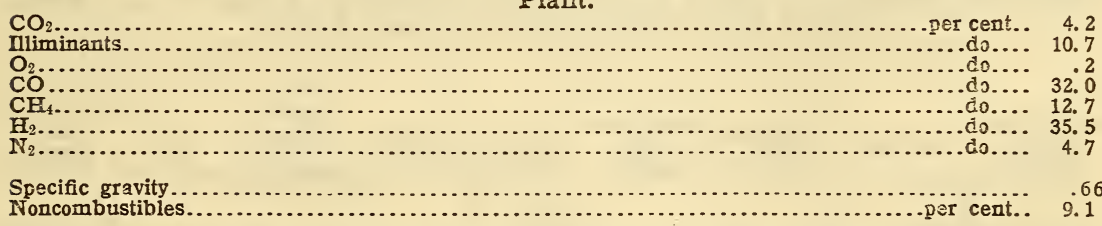

TABLE 26._“550” B. t. u. Water Gas, 0.657 Specific Gravity-Burner No. 1, 48 Ports, No. 40 Drill-Utensil $13 / 8$ Inches from Burner.

\begin{tabular}{|c|c|c|c|c|c|c|c|c|}
\hline $\begin{array}{l}\text { Pressure in } \\
\text { inches } \\
\text { of water. }\end{array}$ & Gas rate. & $\begin{array}{l}\text { Heating } \\
\text { value. }\end{array}$ & $\begin{array}{c}\text { Quantity of } \\
\text { heat } \\
\text { supplied. }\end{array}$ & $\begin{array}{c}\text { Cone } \\
\text { height. }\end{array}$ & $\begin{array}{l}\text { Flame } \\
\text { height. }\end{array}$ & $\begin{array}{c}\text { Time } \\
\text { required } \\
\text { to heat } \\
2 \text { quarts of } \\
\text { water from } \\
80 \text { to } 212^{\circ} \mathrm{F} \text {. }\end{array}$ & $\begin{array}{c}\text { Gas } \\
\text { used. }\end{array}$ & $\begin{array}{l}\text { Effi- } \\
\text { ciency. }\end{array}$ \\
\hline $\begin{array}{l}1 \\
2 \\
3 \\
4 \\
5\end{array}$ & $\begin{array}{c}\text { Ft. } 3 / \mathrm{hr} . \\
9.69 \\
13.95 \\
16.68 \\
19.33 \\
22.22\end{array}$ & $\begin{array}{c}\text { B. t. u./ft. } \text {. }^{3} \\
549 \\
549 \\
557 \\
557 \\
557\end{array}$ & $\begin{array}{c}\text { B. t. u./hr. } \\
5,300 \\
7,660 \\
9,290 \\
10,930 \\
12,390\end{array}$ & $\begin{array}{c}\text { Inch. } \\
0.25 \\
.30 \\
.35 \\
.40 \\
.45\end{array}$ & $\begin{array}{c}\text { Inches. } \\
0.50 \\
.70 \\
.90 \\
1.10 \\
1.30\end{array}$ & $\begin{array}{c}\text { Minutes. } \\
17.79 \\
12.00 \\
9.51 \\
8.05 \\
6.86\end{array}$ & $\begin{array}{l}\text { Feet. }{ }^{3} \\
2.87 \\
2.78 \\
2.64 \\
2.59 \\
2.54\end{array}$ & $\begin{array}{c}\text { Per cent. } \\
35.0 \\
36.1 \\
37.3 \\
38.1 \\
38.9\end{array}$ \\
\hline
\end{tabular}


(b) BURNER No. 2.

Completely closing the air shutter still allowed a little too much air to enter the burner. The flame was a little too hard, so a piece of thin sheet metal was inserted between the air-shutter cap and air mixer, and over the slot for the air-shutter screw. This was not the equivalent of closing the slot because the piece of inserted sheet metal did not permit as close a fit between the airshutter cap and air-shutter mixer as there was before the insertion.

The analysis of the " 550 " B. t. u. water gas is given in Table 25 .

Table 27 and Figures 44 and 45 give the efficiency and operation data obtained with Burner No. 2 and " 550 " B. t. u. water gas.

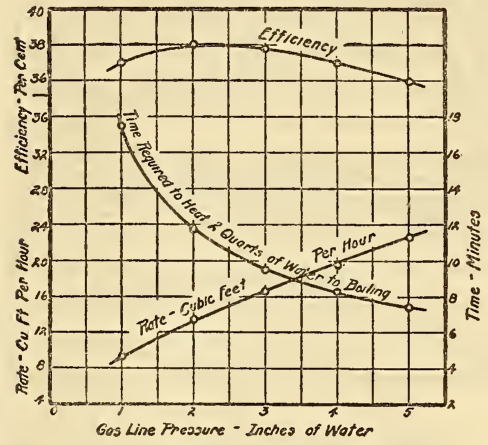

FIG. 44.-Curves showing efficiency, time required, and cubic feet of gas used to heat 2 quarts of water to boiling with water gas of 549 B. $t$. u. and burner No. 2.

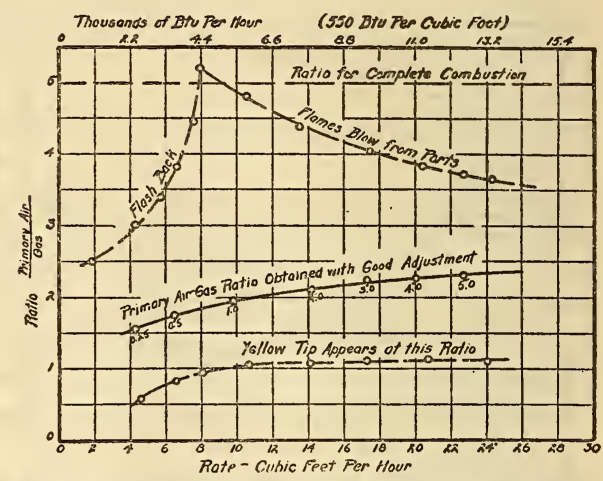

FIG. 45.-Primary air-gas ratio obtained with water gas of 552 B.t. $u$. and burner No. 2 at the different conditions of operation.

Specific gravity of gas, 0.662 .

TABLE 27.-“550" B. t. u. Water Gas, 0.657 Specific Gravity-Burner No. 2, 44 Ports, No. 40 Drill-Utensil $13 / 8$ Inches from Burner.

\begin{tabular}{|c|c|c|c|c|c|c|c|c|}
\hline $\begin{array}{l}\text { Pressure in } \\
\text { inches } \\
\text { of water. }\end{array}$ & Gas rate. & $\begin{array}{l}\text { Heating } \\
\text { value. }\end{array}$ & $\begin{array}{c}\text { Quantity of } \\
\text { heat } \\
\text { supplied. }\end{array}$ & $\begin{array}{c}\text { Cone } \\
\text { height. }\end{array}$ & $\begin{array}{l}\text { Flame } \\
\text { height. }\end{array}$ & $\begin{array}{c}\text { Time } \\
\text { required } \\
\text { to heat } \\
2 \text { quarts of } \\
\text { water from } \\
80 \text { to } 212^{\circ} \mathrm{F} \text {. }\end{array}$ & $\begin{array}{c}\text { Gas } \\
\text { used. }\end{array}$ & $\begin{array}{c}\text { Effi- } \\
\text { ciency. }\end{array}$ \\
\hline $\begin{array}{l}1 \\
2 \\
3 \\
4 \\
5\end{array}$ & $\begin{array}{c}\text { Ft. } 8 / \mathrm{hr} . \\
9.31 \\
13.54 \\
16.68 \\
19.45 \\
22.61\end{array}$ & $\begin{array}{c}\text { B. t. u./ft. }{ }^{3} \\
\mathbf{5 4 9} \\
549 \\
549 \\
549 \\
549\end{array}$ & $\begin{array}{c}\text { B. t. u./hr. } \\
\mathbf{5}, 110 \\
7,440 \\
9,160 \\
10,690 \\
12,420\end{array}$ & $\begin{array}{c}\text { Inch. } \\
0.25 \\
.30 \\
.35 \\
.40 \\
.43\end{array}$ & $\begin{array}{c}\text { Inches. } \\
0.50 \\
.70 \\
.90 \\
1.10 \\
1.28\end{array}$ & $\begin{array}{c}\text { Minutes. } \\
17.45 \\
11.70 \\
9.57 \\
8.30 \\
7.40\end{array}$ & $\begin{array}{l}\text { Feet. }{ }^{3} \\
2.71 \\
2.64 \\
2.66 \\
2.70 \\
2.78\end{array}$ & $\begin{array}{c}\text { Per cent. } \\
37.0 \\
38.0 \\
37.7 \\
37.0 \\
36.0\end{array}$ \\
\hline
\end{tabular}

10. TESTS OF "600" B. T. U. WATER GAS.

(a) BURNER No. 1.

The air-shutter setting for the good adjustment of Burner No. I was about 50 per cent open. After the tests were in progress it was observed that if one opening of the air shutter was closed by 
holding a finger over it the flame was slightly harder than that of the good adjustment. This is contrary to what should be expected when half of the primary air opening is closed after a good adjustment is made. The cause of the irregularity was not thoroughly investigated, but is believed that it was caused by a slight disalignment of the gas stream with the injecting tube of the burner. This matter does not affect our results, but shows the importance of having the gas stream in correct alignment with the injecting tube of the burner where burners are operated with a very low pressure and gas of a high heating value, otherwise sufficient air may not be injected into the burner to secure a good flame.

The average analysis of " 600 " B. t. u. water gas is given in Table 28.

Table 29 and Figures 46 and 47 give the efficiency and complete operation data of Burner No. I with " 600 " B. t. u. water gas.

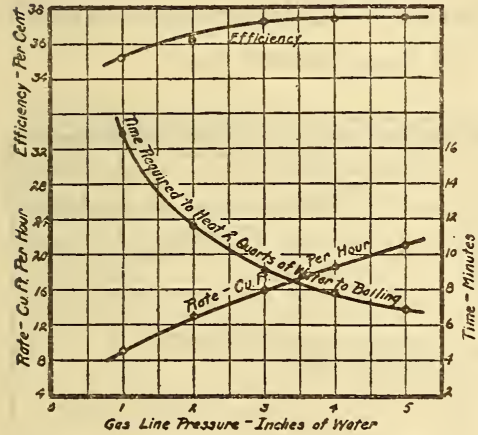

FIG. 46.-Curves showing efficiency, time required, and cubic feet of gas used to heat 2 quarts of water to boiling with water gas of 608 B.t. u. and burner No. I.

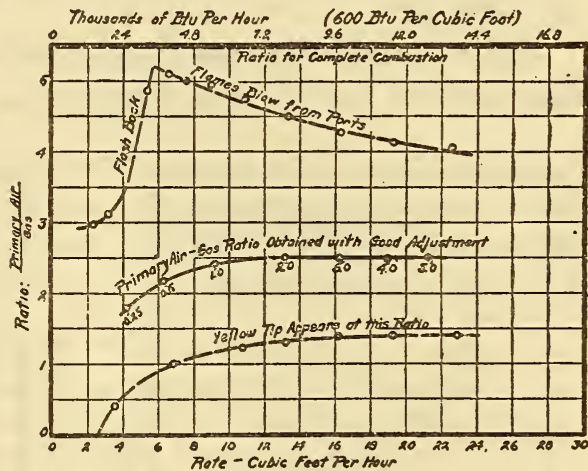

FIG. 47.-Primary air-gas ratio obtained with water gas of 608 B.t. u. and burner No. I at the different conditions of operation.

Specific gravity of gas, 0.682 .

\section{TABLE 28.-Average Analysis of " 600 " B. t. u. Water Gas Made at Spring Gardens Plant.}

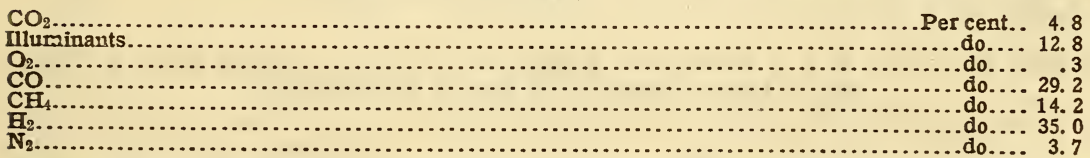


TABLE 29.-“600" B. t. u. Water Gas, 0.682 Specific Gravity-Burner No. 1, 48 Ports, No. 40 Drill-Utensil $13 / 8$ Inches from Burner.

\begin{tabular}{|c|c|c|c|c|c|c|c|c|}
\hline $\begin{array}{l}\text { Pressure in } \\
\text { inches } \\
\text { of water. }\end{array}$ & Gas rate. & $\begin{array}{l}\text { Heating } \\
\text { value. }\end{array}$ & $\begin{array}{c}\text { Quantity of } \\
\text { heat } \\
\text { supplied. }\end{array}$ & $\begin{array}{c}\text { Cone } \\
\text { height. }\end{array}$ & $\begin{array}{l}\text { Flame } \\
\text { height. }\end{array}$ & $\begin{array}{c}\text { Time } \\
\text { required } \\
\text { to heat } \\
2 \text { quarts of } \\
\text { water from } \\
80 \text { to } 212^{\circ} \mathrm{F} \text {. }\end{array}$ & $\begin{array}{c}\text { Gas } \\
\text { used. }\end{array}$ & $\begin{array}{l}\text { Effi- } \\
\text { ciency. }\end{array}$ \\
\hline $\begin{array}{l}\frac{1}{2} \\
3 \\
4 \\
5\end{array}$ & $\begin{array}{c}\text { Ft. } 3 / \mathrm{hr} . \\
9.17 \\
12.91 \\
15.92 \\
18.50 \\
21.03\end{array}$ & $\begin{array}{c}\text { B.t. u./ft. }{ }^{3} \\
608 \\
608 \\
608 \\
608 \\
608\end{array}$ & $\begin{array}{c}\text { B. t. u./hr. } \\
5,500 \\
7,860 \\
9,680 \\
11,250 \\
12,800\end{array}$ & $\begin{array}{c}\text { Inch. } \\
0.25 \\
.33 \\
.40 \\
.45 \\
.50\end{array}$ & $\begin{array}{c}\text { Inches. } \\
0.50 \\
.75 \\
.95 \\
1.15 \\
1.35\end{array}$ & $\begin{array}{c}\text { Minutes. } \\
16.85 \\
11.77 \\
9.14 \\
7.85 \\
6.90\end{array}$ & $\begin{array}{l}\text { Feet. }^{3} \\
2.57 \\
2.50 \\
2.43 \\
2.42 \\
2.42\end{array}$ & $\begin{array}{c}\text { Per cent. } \\
35.2 \\
36.2 \\
37.3 \\
37.4 \\
37.5\end{array}$ \\
\hline
\end{tabular}

(b) BURINER No. 2.

The air shutter was completely closed for the good adjustment of Burner No. 2 because enough primary air entered the burner through the slot for the air-shutter screw, the loose-fitting shutter, and the opening where the mixing tube enters the air mixer.

The average analysis of the " 600 " B. t. u. water gas is given in Table 28.

Table 30 and Figures 48 and 49 contain the efficiency and operation data of Burner No. 2 with " 600 " B. t. u. water gas.

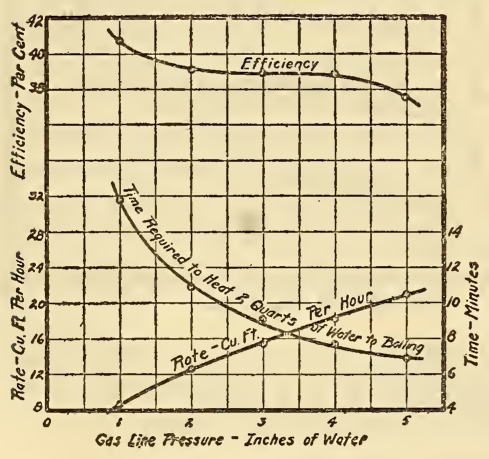

FIG. 48.-Curves showing efficiency, time required, and cubic feet of gas used to heat 2 quarts of water to boiling with water gas of 608 B.t. u. and burner No. 2.

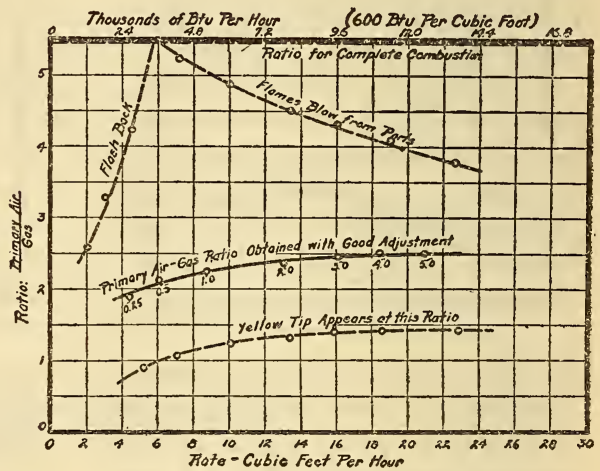

FIG. 49.-Primary air-gas ratio obtained with water gas of 608 B.t. u. and burner No. 2 at the different conditions of operation.

Specific gravity of gas, 0.680 .

TABLE 30.-“600" B. t. u. Water Gas, 0.680 Specific Gravity-Burner No. 2, 44 Ports, No. 40 Drill-Utensil $13 / 8$ Inches from Burner.

\begin{tabular}{|c|c|c|c|c|c|c|c|c|}
\hline $\begin{array}{l}\text { Pressure in } \\
\text { inches } \\
\text { of water. }\end{array}$ & Gas rate. & $\begin{array}{l}\text { Heating } \\
\text { value. }\end{array}$ & $\begin{array}{c}\text { Quantity of } \\
\text { heat } \\
\text { supplied. }\end{array}$ & $\begin{array}{c}\text { Cone } \\
\text { height. }\end{array}$ & $\begin{array}{l}\text { Flame } \\
\text { height. }\end{array}$ & $\begin{array}{c}\text { Time } \\
\text { required } \\
\text { to heat } \\
2 \text { quarts of } \\
\text { water from } \\
80 \text { to } 212^{\circ} \mathrm{F} \text {. }\end{array}$ & $\begin{array}{c}\text { Gas } \\
\text { used. }\end{array}$ & $\begin{array}{l}\text { Effi- } \\
\text { ciency. }\end{array}$ \\
\hline $\begin{array}{l}1 \\
2 \\
3 \\
4 \\
5\end{array}$ & $\begin{array}{l}\text { Ft. }{ }^{3} / \mathrm{hr} . \\
8.68 \\
12.80 \\
15.40 \\
18.18 \\
20.89\end{array}$ & $\begin{array}{c}\text { B. t. u./ft. } \\
608 \\
608 \\
608 \\
608 \\
608\end{array}$ & \begin{tabular}{|c|} 
B. t. u./hr. \\
5,280 \\
7,780 \\
9,360 \\
11,050 \\
12,700
\end{tabular} & $\begin{array}{c}\text { Inch. } \\
0.30 \\
.35 \\
.40 \\
.45 \\
.50\end{array}$ & $\begin{array}{c}\text { Inches. } \\
0.60 \\
.80 \\
.95 \\
1.15 \\
1.35\end{array}$ & $\begin{array}{c}\text { Minutes. } \\
15.35 \\
10.86 \\
9.10 \\
7.89 \\
6.91\end{array}$ & $\begin{array}{l}\text { Feet. } \\
2.22 \\
2.32 \\
2.33 \\
2.33 \\
2.40\end{array}$ & $\begin{array}{c}\text { Per cent. } \\
40.7 \\
39.0 \\
38.9 \\
38.9 \\
37.6\end{array}$ \\
\hline
\end{tabular}




\section{TESTS FOR CARBON MONOXIDE IN THE PRODUCTS OF COMBUSTION.}

The products of combustion from the preceding tests were analyzed in order to determine whether any carbon monoxide was produced. The analyses show that with the "regular" burners used on gas ranges, when properly adjusted, practically no carbon monoxide was produced with any of the gases tested unless gas was burned at a rate greater than about I2,000 B. t. u./hr. Since gas is seldom burned above this rate with burners of "regular" size the danger from carbon-monoxide poisoning is very remote if the burners are properly adjusted. When gas was burned above this rate, the amount of carbon monoxide produced was such as would cause headaches in a poorly ventilated room.

For the larger top burners, which are commonly designated as "giant" burners, the limitation of I2,000 B. t. u./hr. does not apply, although no tests have been made to determine the maximum safe consumption for these burners.

The heating value of the gas or the kind of gas did not seem to be factors affecting the production of carbon monoxide.

\section{SUMMARY OF GAS ANALYSES.}

The average analyses of the different gases tested are given in Table 3I. To make the theoretical calculations shown at the bottom of the table, it was assumed that the constituents of the illuminants of water gas averaged $\mathrm{C}_{2.6} \mathrm{H}_{6.6}$, and that the illuminants of coke-oven and coal gas averaged $\mathrm{C}_{2} \mathrm{H}_{5}$.

TABLE 31.-Average Analyses of Gases Tested at Spring Gardens.

\begin{tabular}{|c|c|c|c|c|c|c|c|c|c|c|}
\hline Kind of gas.. & $\begin{array}{l}\text { City } \\
\text { gas. }\end{array}$ & $\begin{array}{l}\text { Coke- } \\
\text { oven }\end{array}$ & $\begin{array}{l}\text { Coal } \\
\text { gas. }\end{array}$ & \multicolumn{7}{|c|}{ Water gas. } \\
\hline 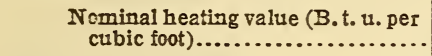 & 500 & 450 & 525 & 300 & 350 & 400 & 450 & 500 & 550 & 600 \\
\hline 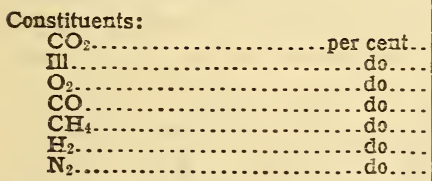 & $\begin{array}{r}4.1 \\
6.5 \\
.8 \\
21.5 \\
16.2 \\
36.6 \\
14.3\end{array}$ & $\begin{array}{r}3.2 \\
3.0 \\
1.0 \\
9.6 \\
22.8 \\
41.5 \\
18.9\end{array}$ & $\begin{array}{r}2.0 \\
3.3 \\
.8 \\
8.2 \\
28.9 \\
49.3 \\
7.5\end{array}$ & $\begin{array}{r}8.2 \\
1.4 \\
.3 \\
34.0 \\
1.9 \\
50.4 \\
3.8\end{array}$ & \begin{tabular}{r|}
7.4 \\
3.2 \\
.7 \\
34.1 \\
3.7 \\
48.1 \\
2.8
\end{tabular} & $\begin{array}{r}6.2 \\
4.5 \\
.2 \\
33.6 \\
6.4 \\
43.8 \\
5.3\end{array}$ & $\begin{array}{r}5.2 \\
5.6 \\
.3 \\
29.4 \\
10.0 \\
42.2 \\
7.3\end{array}$ & $\begin{array}{r}5.1 \\
8.5 \\
.3 \\
32.1 \\
11.2 \\
38.9 \\
3.9\end{array}$ & \begin{tabular}{r|}
4.2 \\
10.7 \\
.2 \\
32.0 \\
12.7 \\
35.5 \\
4.7
\end{tabular} & $\begin{array}{r}4.8 \\
12.8 \\
.3 \\
29.2 \\
14.2 \\
35.0 \\
3.7\end{array}$ \\
\hline 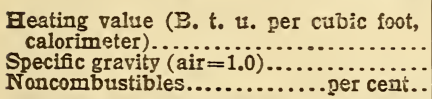 & $\begin{array}{l}496 \\
0.619 \\
10.2\end{array}$ & $\begin{array}{r}450 \\
0.542 \\
23.1\end{array}$ & $\begin{array}{r}524 \\
0.444 \\
10.3\end{array}$ & $\begin{array}{r}298 \\
0.570 \\
12.3\end{array}$ & $\begin{array}{r}354 \\
0.580 \\
10.90\end{array}$ & $\begin{array}{r}400 \\
0.590 \\
11.7\end{array}$ & $\left|\begin{array}{c}451 \\
0.617 \\
12.8\end{array}\right|$ & $\begin{array}{l}501 \\
0.641 \\
9.3\end{array}$ & $\begin{array}{l}556 \\
0.660 \\
9.1\end{array}$ & $\begin{array}{l}603 \\
0.676 \\
8.8\end{array}$ \\
\hline $\left.\begin{array}{l}\text { Required for complete } \\
\text { combustion of } 1 \mathrm{ft} .{ }^{3} \text { of } \\
\text { gas........................ }\end{array}\right\}$ & $\begin{array}{l}.883 \\
4.22\end{array}$ & $\begin{array}{l}.799 \\
3.82\end{array}$ & $\begin{array}{c}.965 \\
4.61\end{array}$ & $\begin{array}{l}.516 \\
2.46\end{array}$ & $\begin{array}{l}.613 \\
2.93\end{array}$ & $\begin{array}{l}.704 \\
3.36\end{array}$ & $\begin{array}{c}.793 \\
3.79\end{array}$ & $\begin{array}{r}.940 \\
4.49\end{array}$ & $\begin{array}{l}1.094 \\
4.99\end{array}$ & $\begin{array}{l}1.148 \\
5.47\end{array}$ \\
\hline 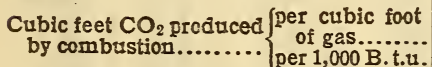 & \} $\begin{array}{c}.587 \\
1.48\end{array}$ & $\begin{array}{l}.416 \\
.925\end{array}$ & $\begin{array}{r}.457 \\
.872\end{array}$ & $\begin{array}{c}.477 \\
1.60\end{array}$ & $\begin{array}{c}.535 \\
1.51\end{array}$ & $\begin{array}{r}.579 \\
1.45\end{array}$ & $\begin{array}{c}.591 \\
1.31\end{array}$ & $\begin{array}{c}.705 \\
1.41\end{array}$ & $\begin{array}{c}.767 \\
1.38\end{array}$ & $\begin{array}{c}.815 \\
1.35\end{array}$ \\
\hline 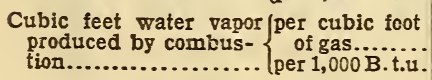 & $\begin{array}{l}.905 \\
1.83\end{array}$ & $\begin{array}{r}.946 \\
2.10\end{array}$ & $\begin{array}{l}1.15 \\
2.20\end{array}$ & $\begin{array}{l}.588 \\
1.97\end{array}$ & $\begin{array}{l}.661 \\
1.87\end{array}$ & $\begin{array}{c}.715 \\
1.79\end{array}$ & $\begin{array}{c}.807 \\
1.79\end{array}$ & $\begin{array}{c}.894 \\
1.79\end{array}$ & $\begin{array}{c}.962 \\
1.73\end{array}$ & $\begin{array}{l}1.06 \\
1.76\end{array}$ \\
\hline
\end{tabular}

\footnotetext{
${ }^{1}$ City gas contained approximately one-third coke-oven gas and two-thirds water gas.
} 


\section{COMPARISON OF RESULTS WITH GASES OF DIFFERENT HEATING VALUES.}

I. Within the range of gas consumption normally used in topburner cooking there will be some variations in the efficiency with the rate of heating. Since this is the case, it appears logical that for an exact comparison of the efficiencies of gases of different heating values the burners must be supplied with the same total quantity of heat units per hour.

2. From observations made by the bureau during service investigations in a large number of cities and from laboratory tests made at the bureau it has been observed that a good average adjustment on a regular burner will represent a consumption of about 9,000 B. t. u./hr. An adjustment for this rate will allow a variation in gas pressure which will be within the usual legal requirements without causing poor service or loss in efficiency. For an example, a burner adjusted to 9,000 B. t. $\mathfrak{u}$. at 3 inches pressure will consume 7,000 B. t. u. at I. 8 inches and will not exceed I I,000 B. t. u. at 4.4 inches pressure.

TABLE 32.-Summary of Tests for Rate of Consumption of 7,000 B.t. u. per HourBurner No. 1, 48 Ports, No. 40 Drill-Utensil 1 3/8 Inches from Burner.

CITY GAS (ONE-THIRD COKE-OVEN GAS, TWO-THIRDS WATER GAS).

\begin{tabular}{|c|c|c|c|c|c|c|c|c|}
\hline \multicolumn{2}{|c|}{ Heating value. } & \multirow{2}{*}{$\begin{array}{c}\text { Specific } \\
\text { gravity } \\
(\text { air=1). }\end{array}$} & \multirow{2}{*}{$\begin{array}{c}\text { Gas } \\
\text { rate } \\
\text { (actual). }\end{array}$} & \multicolumn{2}{|c|}{$\begin{array}{l}\text { Good adjustment of } \\
\text { burner. }\end{array}$} & \multirow{2}{*}{$\begin{array}{l}\text { Time. } \\
\text { required } \\
\text { to heat } \\
2 \text { quarts } \\
\text { of water } \\
\text { from } 80 \text { to } \\
212^{\circ} \mathrm{F} \text {. }\end{array}$} & \multirow{2}{*}{$\begin{array}{c}\text { Gas } \\
\text { used. }\end{array}$} & \multirow{2}{*}{$\begin{array}{l}\text { Effi- } \\
\text { ciency. }\end{array}$} \\
\hline Nominal. & Actual. & & & $\begin{array}{l}\text { Primary } \\
\text { air-gas } \\
\text { ratio. }\end{array}$ & $\begin{array}{l}\text { B.t.u. per } \\
\text { cubic foot } \\
\text { of mixture. }\end{array}$ & & & \\
\hline $\begin{array}{l}\text { B. t. u. } / \text { it. }^{3} \\
500\end{array}$ & B.t.u./ft. ${ }_{492}$ & 0.618 & $\begin{array}{l}\text { Ft. } 3 / \mathrm{hr} . \\
14.23\end{array}$ & 2.15 & 156 & $\begin{array}{l}\text { Minutes. } \\
13.2\end{array}$ & $\begin{array}{l}\text { Foot. }{ }^{3} \\
3.12\end{array}$ & $\begin{array}{c}\text { Per cent. } \\
35.8\end{array}$ \\
\hline
\end{tabular}

CORE-OVEN GAS.

\begin{tabular}{|c|c|c|c|c|c|c|c|c|}
\hline 450 & 447 & 0.55 & 15.66 & 2.0 & 149 & 13.3 & 3.46 & 35.6 \\
\hline \multicolumn{9}{|c|}{ COAL GAS. } \\
\hline 525 & 523 & 0.444 & 13.38 & 2.10 & 169 & 13.0 & 2.90 & 36.3 \\
\hline \multicolumn{9}{|c|}{ WATER GAS. } \\
\hline $\begin{array}{l}300 \\
350 \\
400 \\
450 \\
500 \\
550 \\
600\end{array}$ & $\begin{array}{l}299 \\
356 \\
399 \\
454 \\
505 \\
557 \\
608\end{array}$ & $\begin{array}{r}0.574 \\
.583 \\
.595 \\
.614 \\
.634 \\
.657 \\
.682\end{array}$ & $\begin{array}{l}23.40 \\
19.65 \\
17.54 \\
15.42 \\
13.86 \\
12.57 \\
11.51\end{array}$ & $\begin{array}{r}0.58 \\
.88 \\
1.26 \\
1.52 \\
1.90 \\
2.40 \\
2.47\end{array}$ & $\begin{array}{l}189 \\
189 \\
177 \\
180 \\
179 \\
164 \\
175\end{array}$ & $\begin{array}{l}13.1 \\
13.0 \\
13.1 \\
13.0 \\
12.9 \\
13.2 \\
13.2\end{array}$ & $\begin{array}{l}5.10 \\
4.25 \\
3.83 \\
3.33 \\
2.97 \\
2.77 \\
2.53\end{array}$ & $\begin{array}{l}36.1 \\
36.4 \\
36.0 \\
36.4 \\
36.6 \\
35.7 \\
35.8\end{array}$ \\
\hline
\end{tabular}


Berry, Brumbaugh, Eiseman, ]

Moulton, Shawn

Heating Values and Burner Adjustments.

TABLE 33.-Summary of Tests for Rate of Consumption of 9,000 B. t. u. per HourBurner No. 1, 48 Ports, No. 40 Drill-Utensil $13 / 8$ Inches from Burner.

CITY GAS (ONE-THIRD COKE-OVEN GAS, TWO-THIRDS WATER GAS).

\begin{tabular}{|c|c|c|c|c|c|c|c|c|}
\hline \multicolumn{2}{|c|}{ Heating value. } & \multirow{2}{*}{$\begin{array}{l}\text { Specific } \\
\text { gravity } \\
(\mathrm{air}=1)\end{array}$} & \multirow{2}{*}{$\begin{array}{c}\text { Gas } \\
\text { rate } \\
\text { (actual). }\end{array}$} & \multicolumn{2}{|c|}{$\begin{array}{l}\text { Good adjustment of } \\
\text { bumer. }\end{array}$} & \multirow{2}{*}{$\begin{array}{l}\text { Time. } \\
\text { required } \\
\text { to heat } \\
2 \text { quarts } \\
\text { of water } \\
\text { from } 80 \text { to } \\
212^{\circ} \mathrm{F} \text {. }\end{array}$} & \multirow{2}{*}{$\begin{array}{l}\text { Gas - } \\
\text { used. }\end{array}$} & \multirow{2}{*}{$\begin{array}{c}\text { Effi- } \\
\text { ciency. }\end{array}$} \\
\hline Nominal. & Actual. & & & $\begin{array}{l}\text { Primary } \\
\text { air-gas } \\
\text { ratio. }\end{array}$ & $\begin{array}{l}\text { B. t. u. per } \\
\text { cubic foot } \\
\text { of mixture. }\end{array}$ & & & \\
\hline B. t. u. $/ \mathrm{ft}^{\mathrm{s}}{ }^{3}$ & B. t. un. ${ }_{492}$ ft. ${ }^{3}$ & 0.618 & $\begin{array}{l}\text { Ft. }{ }^{3} / \mathrm{hr} . \\
18.30\end{array}$ & 2.23 & 153 & $\begin{array}{c}\text { Minutes. } \\
10.0\end{array}$ & $\begin{array}{l}\text { Foot. }{ }^{3} \\
3.05\end{array}$ & $\begin{array}{l}\text { Per cent. } \\
36.6\end{array}$ \\
\hline \multicolumn{9}{|c|}{ COIEE-OVEN GAS. } \\
\hline 450 & 447 & 0.55 & 20.12 & 2.06 & 146 & 9.9 & 3.33 & 36.9 \\
\hline \multicolumn{9}{|c|}{ COAI GAS. } \\
\hline 525 & 523 & 0.444 & 17.20 & 2.10 & 169 & 10.0 & 2.86 & 36.7 \\
\hline \multicolumn{9}{|c|}{ WATER GAS. } \\
\hline $\begin{array}{l}300 \\
350 \\
400 \\
450 \\
500 \\
550 \\
600\end{array}$ & $\begin{array}{l}299 \\
356 \\
399 \\
454 \\
505 \\
557 \\
608\end{array}$ & $\begin{array}{l}0.574 \\
.583 \\
.595 \\
.614 \\
.634 \\
.657 \\
.682\end{array}$ & $\begin{array}{l}30.10 \\
25.28 \\
22.55 \\
19.81 \\
17.83 \\
16.16 \\
14.80\end{array}$ & $\begin{array}{l}0.61 \\
.92 \\
1.32 \\
1.53 \\
1.95 \\
2.45 \\
2.48\end{array}$ & $\begin{array}{l}186 \\
185 \\
172 \\
180 \\
171 \\
161 \\
175\end{array}$ & $\begin{array}{r}9.9 \\
10.0 \\
10.0 \\
9.9 \\
9.8 \\
9.9 \\
10.0\end{array}$ & $\begin{array}{l}4.97 \\
4.21 \\
3.75 \\
3.26 \\
2.85 \\
2.66 \\
2.46\end{array}$ & $\begin{array}{l}37.0 \\
36.7 \\
36.7 \\
37.2 \\
37.3 \\
37.1 \\
36.8\end{array}$ \\
\hline
\end{tabular}

TABLE 34.-Summary of Tests for Rate of Consumption of 11,000 B. t. u. per HourBurner No. 1, 48 Ports, No. 40 Drill-Utensil $13 / 8$ Inches from Burner.

CITY GAS (ONE-THIRD COKE-OVEN GAS, TWO-THIRDS WATER GAS).

\begin{tabular}{|c|c|c|c|c|c|c|c|c|}
\hline \multicolumn{2}{|c|}{ Heating value. } & \multirow{2}{*}{$\begin{array}{c}\text { Specific } \\
\text { gravity } \\
(\text { air }=1) .\end{array}$} & \multirow{2}{*}{$\begin{array}{c}\text { Gas } \\
\text { rate } \\
\text { (actual). }\end{array}$} & \multicolumn{2}{|c|}{$\begin{array}{l}\text { Good adjustment of } \\
\text { burner. }\end{array}$} & \multirow{2}{*}{$\begin{array}{c}\text { Time } \\
\text { required } \\
\text { to heat } \\
2 \text { quarts } \\
\text { of water } \\
\text { from } 80 \text { to } \\
212^{\circ} \mathrm{F} \text {. }\end{array}$} & \multirow{2}{*}{$\begin{array}{l}\text { Gas } \\
\text { used. }\end{array}$} & \multirow{2}{*}{$\begin{array}{l}\text { Effi- } \\
\text { ciency. }\end{array}$} \\
\hline Nominal. & Actual. & & & $\begin{array}{l}\text { Primary } \\
\text { air-gas } \\
\text { ratio. }\end{array}$ & $\begin{array}{l}\text { B.t. u.per } \\
\text { cubic foot } \\
\text { of mixture. }\end{array}$ & & & \\
\hline B. t. u./ft. ${ }_{500}^{3}$ & B. t. u./ft. ${ }_{492}$ & 0.618 & $\begin{array}{l}\text { Ft. } 3 / \mathrm{hr} . \\
22.35\end{array}$ & 2.28 & 150 & $\underset{7.9}{\text { Minutes. }}$ & $\begin{array}{l}\text { Feet. } \\
2.94\end{array}$ & $\begin{array}{l}\text { Per cent. } \\
38.0\end{array}$ \\
\hline \multicolumn{9}{|c|}{ COKE-OVEN GAS. } \\
\hline 450 & 447 & 0.55 & 24.60 & 2.10 & 144 & 8.0 & 3.27 & 37.6 \\
\hline \multicolumn{9}{|c|}{ COAL GAS. } \\
\hline 525 & 523 & 0.444 & 21.03 & 2.12 & 168 & 8.0 & 2.82 & 37.3 \\
\hline \multicolumn{9}{|c|}{ WATER GAS. } \\
\hline $\begin{array}{l}300 \\
350 \\
400 \\
450 \\
500 \\
550 \\
600\end{array}$ & $\begin{array}{l}299 \\
356 \\
399 \\
454 \\
505 \\
557 \\
608\end{array}$ & $\begin{array}{r}0.574 \\
.583 \\
.595 \\
.614 \\
.634 \\
.657 \\
.682\end{array}$ & $\begin{array}{l}36.80 \\
30.90 \\
27.57 \\
24.22 \\
21.78 \\
19.75 \\
18.09\end{array}$ & $\begin{array}{l}0.63 \\
.95 \\
1.36 \\
1.54 \\
1.96 \\
2.48 \\
2.48\end{array}$ & $\begin{array}{l}184 \\
183 \\
169 \\
179 \\
171 \\
160 \\
177\end{array}$ & $\begin{array}{l}8.0 \\
8.0 \\
8.0 \\
7.9 \\
8.0 \\
7.9 \\
8.0\end{array}$ & $\begin{array}{l}4.88 \\
4.13 \\
3.67 \\
3.17 \\
2.91 \\
2.58 \\
2.42\end{array}$ & $\begin{array}{l}37.7 \\
37.4 \\
37.6 \\
38.2 \\
37.4 \\
38.2 \\
37.4\end{array}$ \\
\hline
\end{tabular}


(a) RESULTS WITH BURNER NO. 1.

The results of tests of the gases of various heating values with Burner No. I for rates of consumption of $7,000,9,000$, and II, 000 B. t. u./hr. are shown in Tables 32,33 , and 34, respectively.

Values of efficiency obtained with the various heating values, the corresponding rates of consumption in cubic feet per hour, and the time required to heat 2 quarts of water to boiling from $80^{\circ} \mathrm{F}$., as given in Table 33 (9,000 B. t. u./hr.), have been plotted in Figure 50. The tests proved conclusively that when the regular burner No. $I$, which is placed $\mathrm{r} 3 / 8$ inches from the utensil, consumed gas

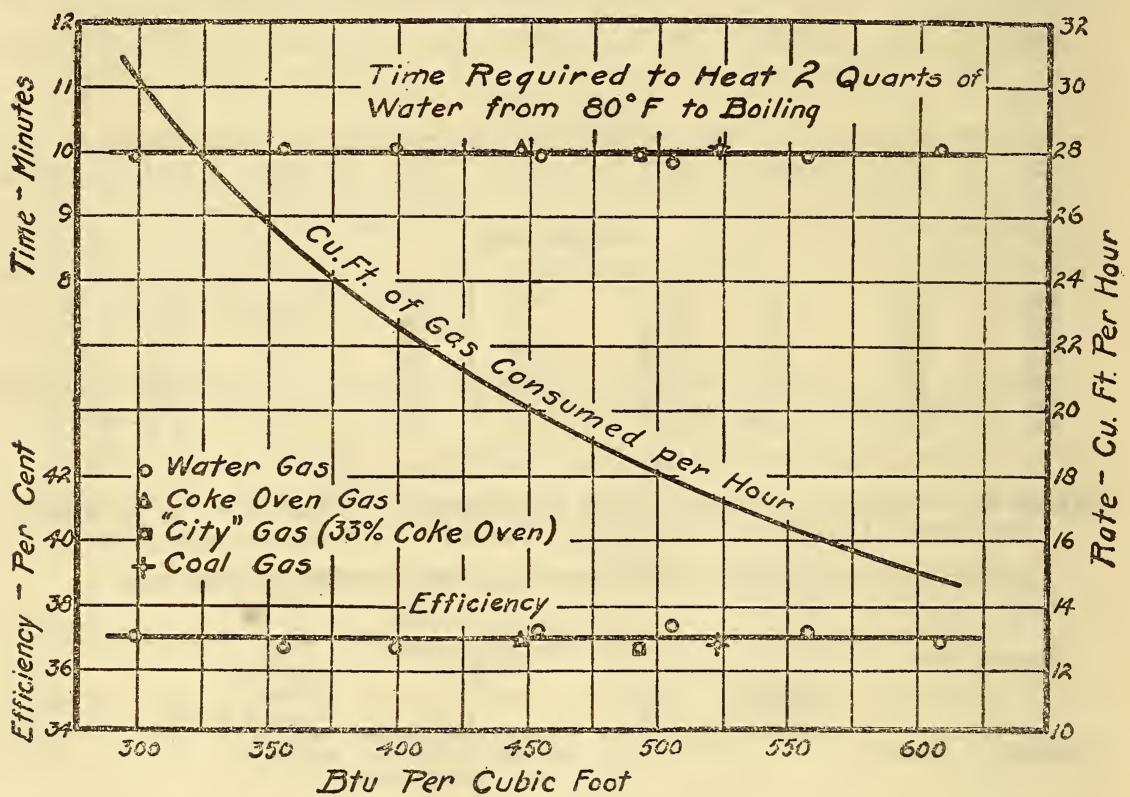

Fig. 50.-Curves showing efficiency, rate of consumption, and time required to heat 2 quarts of water from $80^{\circ} \mathrm{F}$. to boiling when burner No. I is operated at 9,000 B.t.u. per hour with gases of various heating values.

at the rate of 9,000 B.t. u./hr., all the different gases, irrespective of the kind of gas or B.t. u. content per cubic foot, gave a constant efficiency of about 37 per cent, at least within the range of heating values used in these tests $(300$ to $600 \mathrm{~B}$. t. u.). The time required to heat 2 quarts of water to boiling from $80^{\circ} \mathrm{F}$. with 9,000 B. t. u./hr. was about io minutes.

At a rate of 7,000 B. t. u./hr. an average efficiency of about 36 per cent was obtained (see Table 32), and about 13 minutes were required to heat 2 quarts of water to boiling from $80^{\circ} \mathrm{F}$. For a rate of II,000 B. t. u./hr. the average efficiency was about 37.7 per cent (see Table 34), and the time required to heat 2 quarts of 
water to boiling from $80^{\circ} \mathrm{F}$. was about 8 minutes. These results show that the efficiency of heat absorption varies only slightly with a change in the rate of heat supply. It follows, therefore, that the rate of heating varies almost directly with the rate of supply of heat.

(b) RESULTS WITH BURNER NO. 2.

The efficiencies obtained with the gases of different heating value when Burner No. 2 was used are very similar to those obtained with Burner No. I. Both burners were $13 / 8$ inches from top of

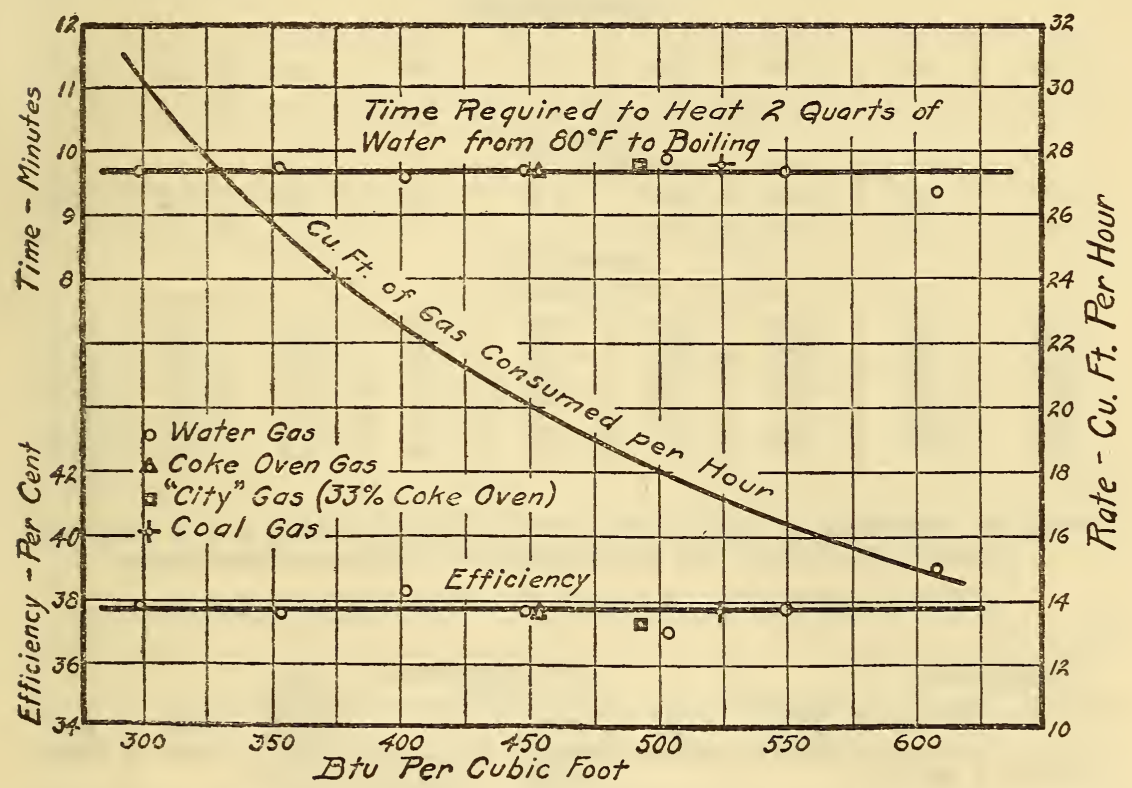

FIG. 5I.-Curves showing efficiency, rate of consumption, and time required to heat 2 quarts of water from $80^{\circ} \mathrm{F}$. to boiling when burner No. 2 is operated at 9,000 B.t.u. per hour with gases of various heating values.

grid (bottom of utensil), but Burner No. 2 has four ports less than No. I and is $3 \frac{5}{8}$ inches in diameter, while No. I is $4 \frac{1}{4}$ inches in diameter.

Tables 35,36 , and 37 , for rates of consumption of $7,000,9,000$, and II,000 B. t. u./hr., respectively, show the efficiencies and operation data obtained with the gases of different heating values with this burner. Values from Table 36 (9,000 B. t. u./hr.) have been plotted in Figure $5 \mathrm{I}$. The results show that with gases of different heating value and a consumption of 9,000 B. t. u./hr. an average efficiency of about 37.8 per cent was obtained and the time required to heat 2 quarts of water to boiling from $80^{\circ} \mathrm{F}$. was about 9.7 minutes. 
TABLE 35.-Summary of Tests for Rate of Consumption of 7,000 B. t. u. per HourBurner No. 2, 44 Ports, No. 40 Drill-Utensil $13 / 8$ Inches from Burner.

CITY GAS (ONE-THIRD COKE-OVEN GAS, TWO-THIRDS WATER GAS).

\begin{tabular}{|c|c|c|c|c|c|c|c|c|}
\hline \multicolumn{2}{|c|}{ Heating value. } & \multirow{2}{*}{$\begin{array}{c}\text { Specific } \\
\text { gravity } \\
(\text { air=1). }\end{array}$} & \multirow{2}{*}{$\begin{array}{c}\text { Gas } \\
\text { rate } \\
\text { (actual). }\end{array}$} & \multicolumn{2}{|c|}{$\begin{array}{l}\text { Good a djustment of } \\
\text { burner. }\end{array}$} & \multirow{2}{*}{$\begin{array}{l}\text { Time } \\
\text { required } \\
\text { to heat } \\
2 \text { quarts } \\
\text { of water } \\
\text { from } 80 \text { to } \\
212^{\circ} \mathrm{F} \text {. }\end{array}$} & \multirow{2}{*}{$\begin{array}{l}\text { Gas } \\
\text { used. }\end{array}$} & \multirow{2}{*}{$\begin{array}{l}\text { Effi- } \\
\text { ciency. }\end{array}$} \\
\hline Nominal. & Actual. & & & $\begin{array}{c}\text { Primary } \\
\text { air-gas } \\
\text { ratio. }\end{array}$ & $\begin{array}{l}\text { B.t.u.per } \\
\text { cubic foot } \\
\text { of mixture. }\end{array}$ & & & \\
\hline B. t. u./ft. ${ }^{3}$ & B. t. u./ft.s & 0.624 & $\begin{array}{l}\text { Ft. } 3 / \mathrm{hr} \text {. } \\
14.22\end{array}$ & 1.81 & 175 & $\begin{array}{l}\text { Minutes. } \\
12.8\end{array}$ & $\begin{array}{l}\text { Feet. } \\
3.02\end{array}$ & $\begin{array}{l}\text { Per cent. } \\
37.0\end{array}$ \\
\hline \multicolumn{9}{|c|}{ COKE-OVEN GAS. } \\
\hline 450 & 453 & 0.54 & 15.45 & 1.61 & 173 & 12.5 & 3.22 & 37.7 \\
\hline \multicolumn{9}{|c|}{ COAL GAS. } \\
\hline 525 & 524 & 0.444 & 13. 25 & 2.05 & 172 & 11.8 & 2.63 & 39.9 \\
\hline \multicolumn{9}{|c|}{ WATER GAS. } \\
\hline $\begin{array}{l}300 \\
350 \\
400 \\
450 \\
500 \\
550 \\
600\end{array}$ & $\begin{array}{l}297 \\
352 \\
401 \\
448 \\
503 \\
549 \\
608\end{array}$ & $\begin{array}{l}0.566 \\
.576 \\
.595 \\
.614 \\
.634 \\
.657 \\
.680\end{array}$ & $\begin{array}{l}23.57 \\
19.88 \\
17.45 \\
15.63 \\
13.91 \\
12.75 \\
11.51\end{array}$ & $\begin{array}{l}0.51 \\
.84 \\
1.27 \\
1.77 \\
1.73 \\
2.08 \\
2.37\end{array}$ & $\begin{array}{l}197 \\
191 \\
177 \\
162 \\
184 \\
178 \\
181\end{array}$ & $\begin{array}{l}12.1 \\
12.2 \\
12.5 \\
12.4 \\
12.7 \\
12.5 \\
12.0\end{array}$ & $\begin{array}{l}4.74 \\
4.05 \\
3.62 \\
3.23 \\
2.94 \\
2.64 \\
2.30\end{array}$ & $\begin{array}{l}39.1 \\
38.6 \\
37.9 \\
38.0 \\
37.2 \\
37.9 \\
39.4\end{array}$ \\
\hline
\end{tabular}

TABLE 36.-Summary of Tests for Rate of Consumption of 9,000 B. t. u. per HourBurner No. 2, 44 Ports, No. 40 Drill-Utensil i 3/8 Inches from Burner.

CITY GAS (ONE-THIRD COKE-OVEN GAS, TWO-THIRDS WATER GAS).

\begin{tabular}{|c|c|c|c|c|c|c|c|c|}
\hline \multicolumn{2}{|c|}{ Ireating value. } & \multirow{2}{*}{$\begin{array}{c}\text { Specific } \\
\text { gravity } \\
(\text { air }=1) .\end{array}$} & \multirow{2}{*}{$\begin{array}{c}\text { Gas } \\
\text { rate } \\
\text { (actual). }\end{array}$} & \multicolumn{2}{|c|}{$\begin{array}{l}\text { Good adjustment of } \\
\text { burner. }\end{array}$} & \multirow{2}{*}{$\begin{array}{l}\text { Time } \\
\text { required } \\
\text { to heat } \\
2 \text { quarts } \\
\text { of water } \\
\text { from } 80 \text { to } \\
212^{\circ} \mathrm{F} \text {. }\end{array}$} & \multirow{2}{*}{$\begin{array}{c}\text { Gas } \\
\text { used. }\end{array}$} & \multirow{2}{*}{$\begin{array}{c}\text { Effi- } \\
\text { ciency. }\end{array}$} \\
\hline Nominal. & Actual. & & & $\begin{array}{l}\text { Primary } \\
\text { air-gas } \\
\text { ratio. }\end{array}$ & $\begin{array}{l}\text { B.t.u.per } \\
\text { cubic foot } \\
\text { of mixture. }\end{array}$ & & & \\
\hline B. t. u./ft. ${ }^{3}$ & ${ }_{492}^{\text {B. t. u. } / \text { ft. }^{3}}$ & 0.624 & $\begin{array}{l}\text { Ft. } 3 / \mathrm{hr} . \\
18.30\end{array}$ & 1.87 & 171 & $\begin{array}{l}\text { Minutes. } \\
\quad 9.8\end{array}$ & $\begin{array}{l}\text { Feet. }{ }^{3} \\
3.00\end{array}$ & $\begin{array}{c}\text { Per cent. } \\
37.3\end{array}$ \\
\hline \multicolumn{9}{|c|}{ COKE-OVEN GAS. } \\
\hline 450 & 453 & 0.54 & 19. 86 & 1.73 & 166 & 9.7 & 3.22 & 37.7 \\
\hline \multicolumn{9}{|c|}{ COAL GAS. } \\
\hline 525 & 524 & 0.444 & 17.16 & 2.12 & 168 & 9.7 & 2.78 & 37.8 \\
\hline \multicolumn{9}{|c|}{ WATER GAS. } \\
\hline $\begin{array}{l}300 \\
350 \\
400 \\
450 \\
500 \\
550 \\
600\end{array}$ & $\begin{array}{l}297 \\
352 \\
401 \\
448 \\
503 \\
549 \\
608\end{array}$ & $\begin{array}{l}0.566 \\
.576 \\
.595 \\
.614 \\
.634 \\
.657 \\
.680\end{array}$ & $\begin{array}{l}30.30 \\
25.58 \\
22.44 \\
20.10 \\
17.89 \\
16.40 \\
14.80\end{array}$ & $\begin{array}{l}0.52 \\
.90 \\
1.30 \\
1.87 \\
1.81 \\
2.18 \\
2.45\end{array}$ & $\begin{array}{l}195 \\
185 \\
174 \\
156 \\
179 \\
173 \\
176\end{array}$ & $\begin{array}{l}9.7 \\
9.8 \\
9.6 \\
9.7 \\
9.9 \\
9.7 \\
9.4\end{array}$ & $\begin{array}{l}4.89 \\
4.15 \\
3.58 \\
3.26 \\
2.95 \\
2.65 \\
2.33\end{array}$ & $\begin{array}{l}37.9 \\
37.6 \\
38.3 \\
37.7 \\
37.0 \\
37.8 \\
38.9\end{array}$ \\
\hline
\end{tabular}


TABLE 37.-Summary of Tests for Rate of Consumption of 11,000 B. t. u. per HourBurner No. 2, 44 Ports, No. 40 Drill-Utensil $13 / 8$ Inches from Burner.

CITY GAS (ONE-THIRD COKE-OVEN GAS, TWO-THIRDS WATER GAS).

\begin{tabular}{|c|c|c|c|c|c|c|c|c|}
\hline \multicolumn{2}{|c|}{ Heating value. } & \multirow{2}{*}{$\begin{array}{l}\text { Specific } \\
\text { gravity } \\
(\mathrm{air}=1) .\end{array}$} & \multirow{2}{*}{$\begin{array}{c}\text { Gas } \\
\text { rate } \\
\text { (actual). }\end{array}$} & \multicolumn{2}{|c|}{$\begin{array}{l}\text { Good adjustment of } \\
\text { burner. }\end{array}$} & \multirow{2}{*}{$\begin{array}{l}\text { Time } \\
\text { required } \\
\text { to heat } \\
2 \text { quarts } \\
\text { of water } \\
\text { from } 80 \text { to } \\
212^{\circ} \mathrm{F} \text {. }\end{array}$} & \multirow{2}{*}{$\begin{array}{l}\text { Gas - } \\
\text { used. }\end{array}$} & \multirow{2}{*}{$\begin{array}{l}\text { Effi- } \\
\text { ciency. }\end{array}$} \\
\hline Nominal. & Actual. & & & $\begin{array}{l}\text { Primary } \\
\text { air-gas } \\
\text { ratio. }\end{array}$ & $\begin{array}{l}\text { B.t.u.per } \\
\text { cubic foot } \\
\text { of mixture. }\end{array}$ & & & \\
\hline $\begin{array}{c}\text { B. t. u. } / \mathrm{ft}^{3}{ }^{3} \\
500\end{array}$ & $\begin{array}{c}\text { B. t. u./ft. }{ }^{3} \\
492\end{array}$ & 0.624 & $\begin{array}{c}\text { Ft. } 3 / \mathrm{hr} . \\
22.35\end{array}$ & 1.90 & 170 & $\begin{array}{l}\text { Minutes. } \\
8.0\end{array}$ & $\begin{array}{c}\text { Feet. }{ }^{3} \\
2.98\end{array}$ & $\begin{array}{c}\text { Per cent. } \\
37.5\end{array}$ \\
\hline
\end{tabular}

COKE-OVEN GAS.

\begin{tabular}{|c|c|c|c|c|c|c|c|c|}
\hline 450 & 453 & 0.540 & 24.28 & 1.81 & 161 & 8.0 & 3.24 & 37.5 \\
\hline \multicolumn{9}{|c|}{ COAL GAS. } \\
\hline 525 & 524 & 0.444 & 21.0 & 2.18 & 165 & 8.2 & 2.86 & 36.7 \\
\hline \multicolumn{9}{|c|}{ WATER GAS. } \\
\hline $\begin{array}{l}300 \\
350 \\
400 \\
450 \\
500 \\
550 \\
600\end{array}$ & $\begin{array}{l}297 \\
352 \\
401 \\
448 \\
503 \\
549 \\
608\end{array}$ & $\begin{array}{r}0.566 \\
.576 \\
.595 \\
.614 \\
.634 \\
.657 \\
.680\end{array}$ & $\begin{array}{l}37.03 \\
31.25 \\
27.42 \\
24.54 \\
21.86 \\
20.03 \\
18.08\end{array}$ & $\begin{array}{r}0.53 \\
.99 \\
1.35 \\
1.94 \\
1.85 \\
2.27 \\
2.48\end{array}$ & $\begin{array}{l}194 \\
177 \\
171 \\
153 \\
176 \\
168 \\
175\end{array}$ & $\begin{array}{l}8.1 \\
8.1 \\
7.8 \\
8.0 \\
8.1 \\
8.1 \\
7.7\end{array}$ & $\begin{array}{l}4.99 \\
4.21 \\
3.55 \\
3.26 \\
2.96 \\
2.72 \\
2.32\end{array}$ & $\begin{array}{l}37.1 \\
37.1 \\
38.6 \\
37.6 \\
36.9 \\
36.9 \\
38.9\end{array}$ \\
\hline
\end{tabular}

(c) EFFECT OF ROOM TEMPERATURE ON EFFICIENCY TESTS.

Some investigators claim that in order to get consistent and reproducible results in the efficiency values it is mecessary to have a very constant room temperature. In these tests it was impossible to control the room temperature, but in making a study of the efficiency results and the room temperature at the time of the tests, it is impossible to find any indication that the variation in temperature affected the results.

Table 38 shows average room temperatures during the time that each series of efficiency tests were made.

TABLE 38.-Average Room Temperatures During Effliency Tests.

\begin{tabular}{|c|c|c|c|c|c|c|c|c|c|c|}
\hline \multirow{2}{*}{$\begin{array}{l}\text { Kind of gas............. } \\
\begin{array}{l}\text { Nominal heating value } \\
\text { (B. t. u. per cubic foot). }\end{array}\end{array}$} & \multicolumn{7}{|c|}{ Water gas. } & \multirow{2}{*}{$\begin{array}{r}\text { City } \\
\text { gas. } \\
500\end{array}$} & \multirow{2}{*}{$\begin{array}{c}\begin{array}{c}\text { Coke- } \\
\text { oven. } \\
\text { gas. }\end{array} \\
\\
450\end{array}$} & \multirow{2}{*}{$\begin{array}{r}\text { Coal } \\
\text { gas. } \\
525\end{array}$} \\
\hline & 300 & 350 & 400 & 450 & 500 & 550 & 600 & & & \\
\hline $\begin{array}{l}\text { Room temperature: } \\
\quad \text { Burner No. } 1 \ldots \ldots \ldots \ldots \ldots \ldots \\
\text { Burner No. } 2 \ldots \ldots \ldots \ldots \ldots \ldots\end{array}$ & $\begin{array}{l}82 \\
79\end{array}$ & $\begin{array}{l}86 \\
86\end{array}$ & $\begin{array}{l}94 \\
99\end{array}$ & $\begin{array}{l}98 \\
92\end{array}$ & $\begin{array}{l}83 \\
79\end{array}$ & $\begin{array}{l}87 \\
88\end{array}$ & $\begin{array}{l}82 \\
83\end{array}$ & $\begin{array}{l}80 \\
89\end{array}$ & $\begin{array}{l}84 \\
85\end{array}$ & $\begin{array}{l}75 \\
77\end{array}$ \\
\hline
\end{tabular}




\section{ADJUSTMENT OF BURNERS FOR GASES OF DIFFERENT HEATING VALUE AND SPECIFIC GRAVITY.}

The different factors that enter into the proper adjustment of a burner are (I) heating value of the gas; (2) quantity of heat required; (3) kind of gas; (4) gas pressure; (5) specific gravity; and (6) type of air mixer, air shutter, injecting tube, and size of orifice.

The heating value determines the volume of gas that must be supplied the burner. A change of heating value changes the ratio of primary air to gas required for a good flame, and generally necessitates a change of size of orifice and the position of the air shutter.

The kind of gas affects the ease of operation of a burner. Coal and coke oven gas are less susceptible to flash back than water gas, which means that the range of adjustment for good operation is greater than with water gas.

The volume of air injected into a burner is dependent upon the energy of the gas stream, which varies with the volume consumed, the pressure, and the specific gravity of the gas. A change of any one of these factors may necessitate a change of the orifice and the air-shutter position.

The range of heating value to which the burners can be adjusted will depend upon the pressure of the gas, the design of air mixer, air shutter, and injecting tube. There are a few burners of obsolete design in service which do not have an adjustable air shutter and it is more difficult to make adjustments for low heating value gases with such burners.

\section{(a) ADJUSTMENT OT BURNER NFO. 1.}

The adjustment of Burner No. I to consume gases of different heating values warrants the conclusion that the burner can be used without alteration to give good service with water gas of a heating value as low as $350 \mathrm{~B}$. $t$. $u$. $/ \mathrm{ft}^{{ }^{3}}$ The adjustment for each of the different heating values was made when the pressure was 3 inches. This burner is representative of the "star" type. Star burners are most widely used.

(b) ADJUSTMENT OF BURNER NO. 2.

Burner No. 2, which was tested, and which is shown in Figure 2, is one of the older designs and is of the "disk" type. On account of its loose fitting air mixer and air shutter it could not be used with water gas of a heating value lower than about $450 \mathrm{~B}$. $t$. $u$. and a pressure of 3 inches without devising some means to obstruct the flow of primary air into the burner. 
V. GAS PRESSURE NECESSARY FOR GOOD ADJUSTMENT OF BURNER NO. 1 WITH "500" AND "600" B. T. U. WATER GAS.

When the air shutter of a burner must be partly or almost completely closed to obtain a "good adjustment" it indicates that the burner could be operated equally as well at a lower pressure by using a larger orifice and a larger opening of the air shutter. It is interesting to know what is the minimum pressure required to produce a good flame when the air shutter is in the wide-open position.

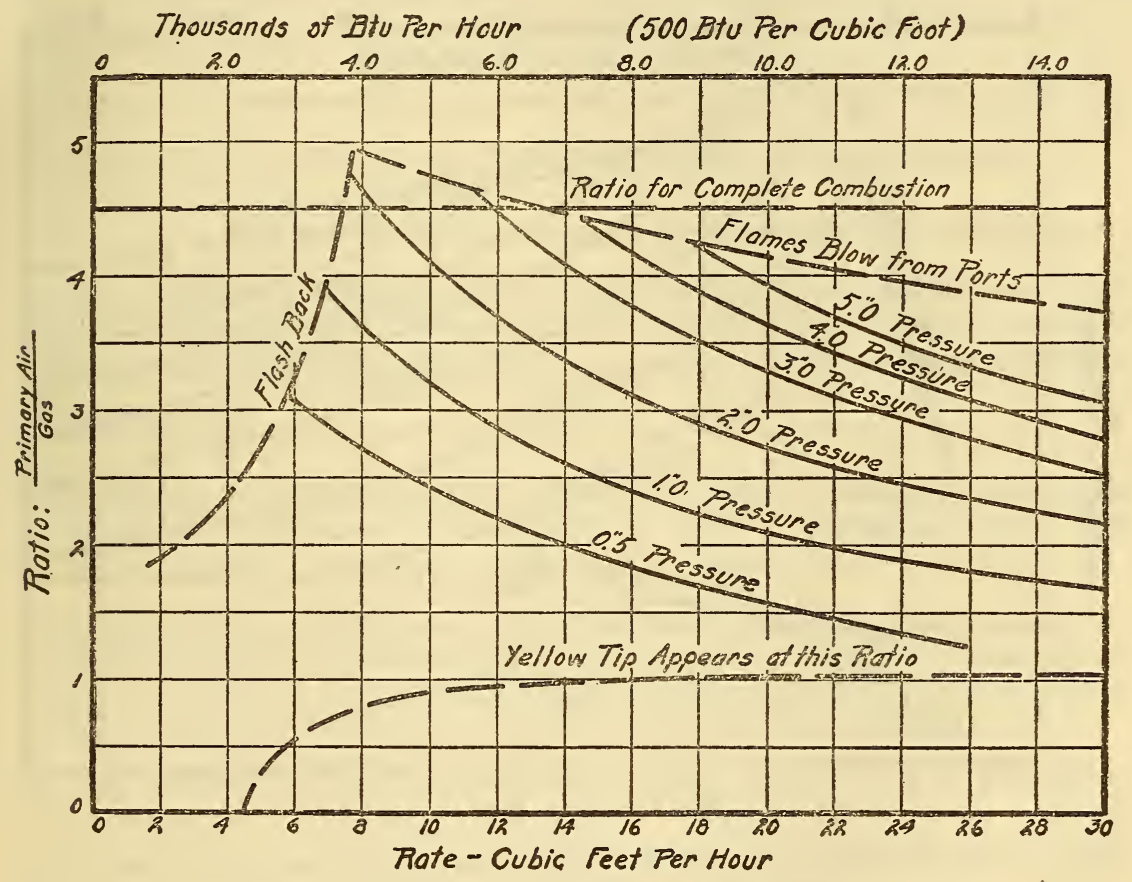

FIG. 52.-Air.gas ratios obtained at different pressures and gas rates with burner No. I when operated with water gas of 501 B. t. $u$.

Specific gravity of gas, 0.633 . Air shutter wide open.

The required pressure will vary with (I) the design of injecting tube of burner, (2) the type of orifice (fixed orifices require less pressure than adjustable orifices), (3) the specific gravity of the gas, and (4) the heating value of the gas.

TEST No. I.-Conditions of test: (I) Air shutter wide open, (2) specific gravity of gas 0.633 , (3) water gas, 5or B. t. u./ft. ${ }^{3}$, and (4) fixed orifices (sharp-edge type).

Figure $5^{2}$ shows the ratios of air to gas that were obtained with different rates of consumption and pressures of $0.5,1,2,3,4$, and $110180^{\circ}-22-4$ 
5 inches when the air shutter was wide open. Orifices of different sizes were used in order to determine these curves. This figure shows that when the gas pressure is constant and the gas rate is changed by changing the size of the orifice, the air-gas ratio decreases as the gas rate increases. Thus the minimum pressure required to produce the proper air-gas ratio is the pressure that will give a good adjustment at the maximum rate at which the burner is to be operated. If 10,000 heat units per hour are taken as the correct consumption for a regular burner, the gas rate

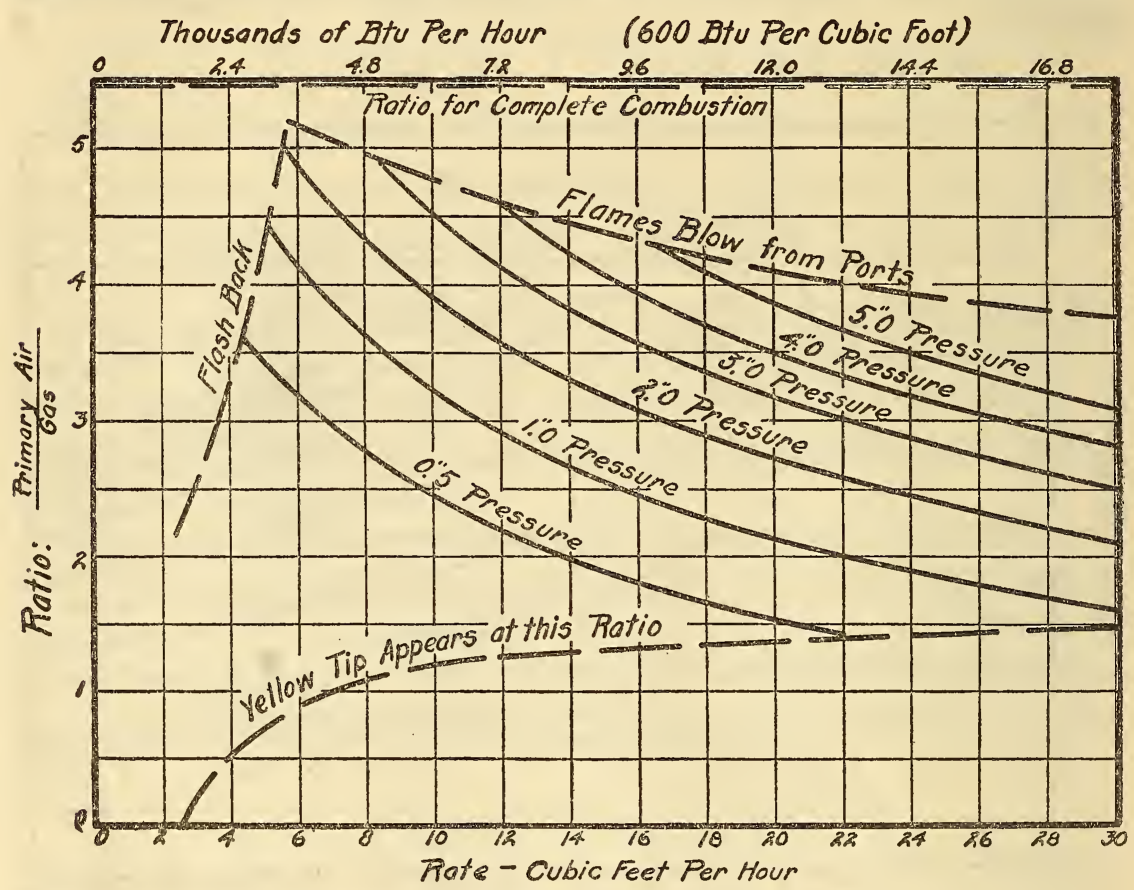

FIG. 53.-Air-gas ratios obtained at different pressures and gas rates with burner No. I when operated with waier gas of 608 B. t. u.

Specific gravity of gas, 0.682. Air shutter wide open.

with $500 \mathrm{~B}$. t. u. gas will be $20 \mathrm{ft}^{3} / \mathrm{hr}$. From Figure 39 , the tests of which were made with $500 \mathrm{~B}$. t. u. water gas, it will be noted that the "good adjustment" at this rate is secured with an air-gas ratio of 1.95 . Figure 52 shows that when the air shutter is wide open a pressure of about seventh-eighth inch will produce this air-gas ratio at a gas rate of $20 \mathrm{ft} .{ }^{3} / \mathrm{hr}$. A pressure of $\mathrm{I}$ inch, therefore, is sufficient to inject the proper amount of air when the burner is supplied with not more than ro,o0o B. t. u./hr.

It follows that Burner No. $I$, if operated with water gas of 0.63 specific gravity and "50o" B. t. u./ft." would not need an ad- 
TABLE 45.-Carbon Monoxide in Products of Combustion from "600" B. t. u. Water Gas When Burner is at Different Distances from Utensil-Burner No. 3, 45 Ports, No. 38 Drill.

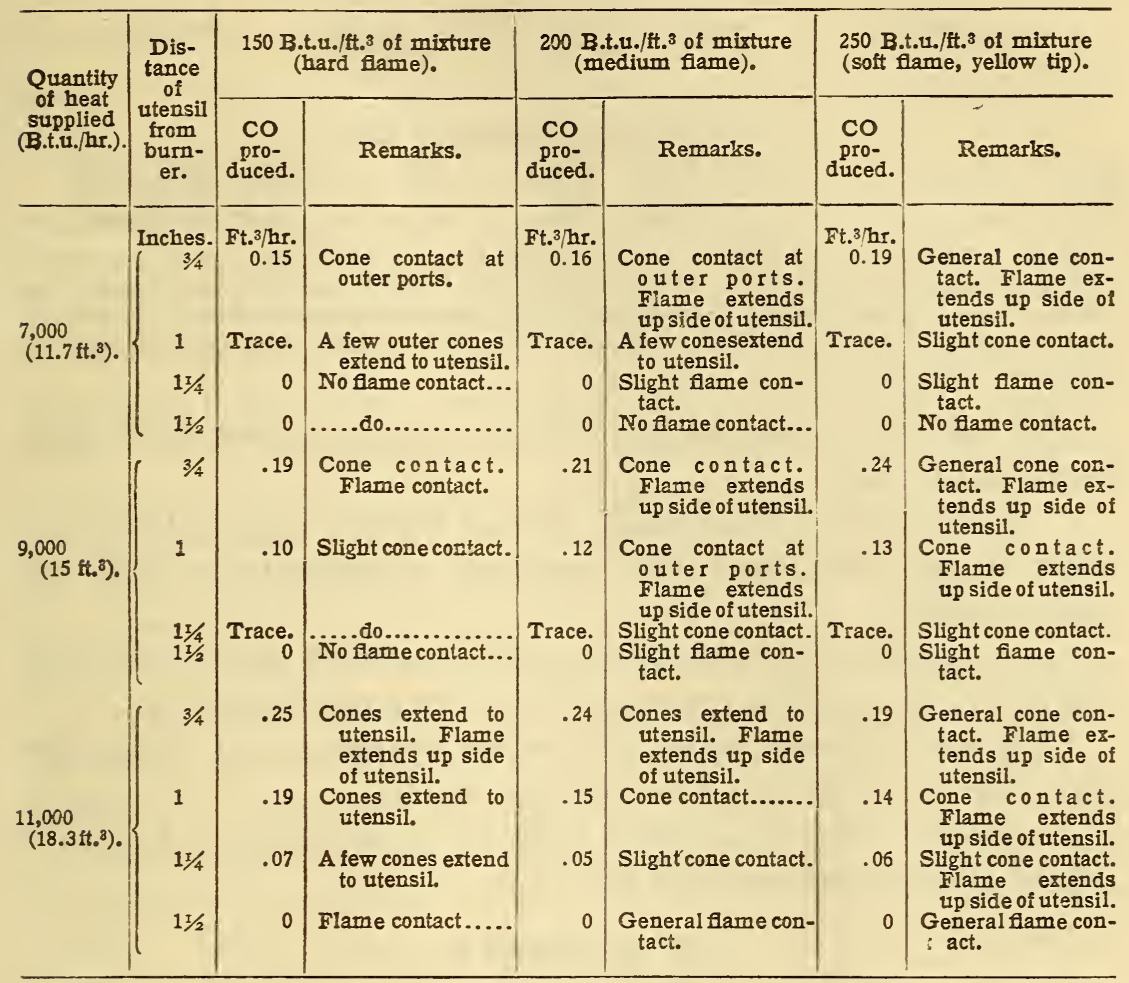

IX. EFFECT OF CAREFUL OPERATION OF GAS BURNERS ON GAS CONSUMPTION.

Many cooking processes require the heating of the water in the utensil up to boiling and the maintenance of the boiling temperature $\left(2 \mathrm{I} 2^{\circ} \mathrm{F}\right.$.) thereafter until the food is completely cooked. Some people forget or do not know that water can not be heated to a temperature higher than $22^{\circ} \mathrm{F}$. at atmospheric pressure and that violent boiling does not accelerate the speed of cooking. It only evaporates water needlessly, wastes gas, and causes the consumer to complain of high gas bills.

Some idea of the difference between careless operation and careful operation of an appliance can be gained from the tests reported in Table 46. 
TABLE 46.-Tests of Evaporation of Water with "City Gas" of 502 B. t. u.

\begin{tabular}{|c|c|c|c|c|c|}
\hline Test No. & Gas rate. & $\begin{array}{c}\text { Quantity } \\
\text { of heat } \\
\text { supplied. }\end{array}$ & $\begin{array}{l}\text { Quantity } \\
\text { of water } \\
\text { used. }\end{array}$ & $\begin{array}{l}\text { Time re- } \\
\text { quired for } \\
\text { complete } \\
\text { evapora- } \\
\text { tion. }\end{array}$ & Remarks. \\
\hline 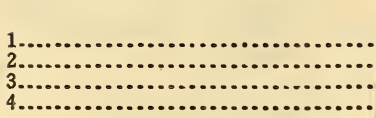 & $\begin{array}{r}\text { Ft. } 3 / \mathrm{hr} . \\
2.05 \\
10.62 \\
18.42 \\
18.50\end{array}$ & \begin{tabular}{|r|} 
B. t. u. $/ \mathbf{h r}$. \\
$\mathbf{1 , 0 3 0}$ \\
$\mathbf{5}, 330$ \\
9,250 \\
$\mathbf{9}, 290$
\end{tabular} & $\begin{array}{r}\text { Quarts. } \\
2 \\
2 \\
2 \\
2\end{array}$ & $\begin{array}{r}\text { Hours. } \\
9.15 \\
1.49 \\
1.13 \\
1.10\end{array}$ & $\begin{array}{l}\text { Lid on, gentle boiling. } \\
\text { Lid off, gentle boiling. } \\
\text { Lid on, violent boiling. } \\
\text { Lid off, violent bolling. }\end{array}$ \\
\hline
\end{tabular}

NoTE.-To make the lid-on tests a piece of plate glass was placed over the utensil in order to observe the degree of boiling. A small opening corresponding to a loose-fitting lid allowed the steam to escape. In tests Nos. I and 2 the water was in a state of gentle boiling, whereas in Nos. 3 and 4 the water was violently agitated by the boiling.

The following important conclusions may be drawn from these evaporation tests:

I. With a lid on the utensil, violent boiling (gas on full) consumes about nine times more gas than is necessary to maintain gentle boiling.

2. For gentle boiling about five times as much gas is used with the lid off as would be required if a lid were on the utensil.

3. When violently boiled the water evaporates at about the same rate with the lid on as with the lid off.

4. Gentle boiling evaporates water about six times as fast with the lid off as compared with the lid on.

\section{SUMMARY.}

In connection with an investigation conducted by the Public Service Commission of Maryland to determine the most economic heating-value standard for manufactured gas in the city of Baltimore, the Bureau of Standards carried on an extensive series of laboratory tests of gases of different heating value and composition.

In this report of the laboratory tests are discussed three of the many important factors that must be considered in determining the relative service value of different gases. They are (I) what is the relative utilization efficiency of gases of different heating value when each gas is tested under the most practical conditions? (2) to what extent can the present appliances be adapted to give good and efficient service with gases of different heating value and composition? (3) what adjustment in appliances is necessary to give the consumers good and efficient service when different kinds of gases are mixed and the composition, heating value, and the specific gravity change as a result of daily and seasonal variations in the send out? 


\section{RELATIVE UTILIZATION EFFICIENCY OF GASES OF DIFFERENT HEATING VALUE.}

Since it is desirable to compare the relative efficiency of gases of different heating value under conditions most favorable to each gas, it is necessary to consider the effect of air-shutter adjustment, distance of utensil from the burner, and the gas rate.

The efficiency of a burner varies with the type of flame. The size and appearance of a flame depend upon the composition of the gas, the gas rate, the heating value, and the primary air-gas ratio. The heating value and ratio of primary air to gas determine the B. t. u. per cubic foot of the mixture within the burner. An adjustment that gives a mixture of gas and air within the burner with a heating value of $250 \mathrm{~B}$. t. u./ft. ${ }^{3}$ gives a very soft flame, while a mixture of I $_{5} \mathrm{OB}$. t. u. $\mathrm{ut} .^{3}$ gives a very hard flame. The good adjustment for all the gases showed that the mixture had an average heating value of about I 75 B.t. u./ft.. ${ }^{3}$ If the gas rate is varied over the usual range of adjustment by a change in the pressure at the gas orifice, the flame volume will vary, but the B. t. u. per cubic foot of mixture remains practically constant and the flame will possess almost the same degree of "hardness" or "softness" (depending on the initial adjustment).

With a hard flame the efficiency tends to increase slightly with an increase in gas rate for any one distance of the utensil from burner. This is true, in general, except when the utensil is placed three-fourths inch or less from the burner. There is a difference in flame volume according to whether the adjustment is made for a soft, medium, or hard flame. It is evident, therefore, that when the utensil is in any one position the flame contact for these three adjustments will not be the same and, therefore, the efficiency will differ.

The distance between the burner and the utensil has a marked effect on the efficiency. The efficiency varies inversely as the distance between the utensil and burner and tends to increase with the amount of flame contact until the flame extends up the side of the utensil. When this occurs a large part of the available heat in the flame is lost by radiation and convection and the efficiency decreases.

Maximum efficiency can not be secured because of formation of carbon monoxide at close position of the utensil to burner. A distance of three-fourths inch, or less, would give the maximum efficiency; but when a utensil is placed so close to a burner that there is cone contact, carbon monoxide is produced. Since this 
gas, even when present in the room atmosphere in small quantities, is detrimental to health, it is advisable to place the utensil at a distance from the burner that will give the highest efficiency without the formation of carbon monoxide. The results of these tests show that for the size of vessel used the minimum distance should be about I inch for Burner No. I, while for Burner No. 3 the vessel should not be placed closer than about $\mathrm{I} / 2$ inches.

With burners properly located and adjusted the danger from carbon monoxide is remote with normal rates of gas consumption. The analyses show that with the ranges used, the burners of which were $I 3 / 8$ inches from the vessel, practically no carbon monoxide was produced with any of the gases tested, unless gas was burned at a rate greater than about $\mathrm{I} 2,000 \mathrm{~B}$. t. $\mathrm{u}$./hr. Above this rate the amount of carbon monoxide produced was sufficient to cause headaches in a poorly ventilated room. The tests showed that the disk type of burner produced more carbon monoxide than the star type, when operated at the same distance ( $13 / 8$ inches) from utensil and at the same rate of consumption.

Although the production of carbon monoxide varied with the position and adjustment of burner and the rate of consumption, if the gases are compared under conditions that are considered proper for each gas, it can be said that the heating value or the kind of gas did not seem to be factors affecting the production of carbon monoxide.

After giving due consideration to the before-mentioned factors which have an influence on efficiency, we can draw the following conclusions from these laboratory tests:

(I) Irrespective of the heating value of the gas, the efficiency (ratio of heat absorbed to heat contained in the gas burned) obtained with any one burner is very nearly constant, provided the burner is adjusted to consume the same number of $B . t$. $u$. per hour with each gas. Thus, to heat a given quantity of water to the same temperature in the same time required 2 feet $^{3}$ of 300 B. t. u. gas to I foot ${ }^{3}$ of 600 B. t. u. gas. In other words, the quantity of gas required varied inversely with the heating value of the gas.

(2) When the burners of standard size were adjusted for a gas rate of 9,000 B. t. u./hr., an efficiency of about 37 per cent was secured, and it required almost exactly ro minutes to heat 2 quarts of water from $80^{\circ} \mathrm{F}$. to boiling with each kind of gas. (See Table 33 and Fig. 5o.) At a rate of 7,000 B.t. u./hr. an average efficiency of about 36 per cent was obtained with Burner No. I (see Table 32) and about I 3 minutes were required. For a rate of II,000 
B. t. u./hr. the average efficiency was about 37.7 per cent (see Table 34 ) and the time required was about 8 minutes. These results show that over the range of usual operating conditions the efficiency of heat absorption varies only slightly with a change in the rate of heat supply. It follows, therefore, that the rate of heating varies almost directly with the rate of supply of heat.

\section{EXTENT TO WHICH THE PRESENT APPLIANCES CAN BE ADAPTED TO GIVE GOOD AND EFFICIENT SERVICE WITH GASES OF DIFFERENT HEATING VALUE AND COMPOSITION.}

(I) Appliances require less pressure to give good combustion with lower heating value gases. Tests of Burner No. I show that with 500 B. t. u. water gas a pressure of $\mathrm{I}$ inch is sufficient to give the required primary air for good adjustment, and with $600 \mathrm{~B}$. t. u. water gas a pressure of about $\mathrm{I} / 4$ inches is sufficient.

The best results are secured from appliances when the gas pressure is constant and the appliance is adjusted to give sufficient heat and good combustion at the average rate required for cooking. Since it is not economical to distribute gas at a very low pressure, the burners are usually adjusted for a pressure much higher than is actually required for a good operation of the appliance. In other words, the pressure that is carried in the gas mains is not determined entirely by the requirements of the appliances, but by distribution costs. Complaints of poor pressure are, therefore, often due not to insufficient pressure in the mains but to improper adjustment of the appliarces.

(2) Burner No. 2 could be adjusted to 450 B. t. u. gas with a 3-inch pressure without any changes in the burner. With a gas of any lower heating value, a tighter-fitting air shutter would be required for a proper regulation of the primary air.

Burner No. I could be adjusted to $35^{\circ}$ B. t. u. gas without any change in the appliance.

(3) The range of workable adjustments of a burner with coal gas is somewhat greater than with water gas. The tests show that the yellow flame occurs at a higher B. t. u. per cubic foot of mixture (lower air-gas ratio) and the upper limit of workable adjustment at a lower B. t. u. per cubic foot of mixture (higher air-gas ratio) with coal gas than with water gas.

The results on the whole show that present domestic range burners can be adjusted to give satisfactory service over a wide range in heating value, the slight differences in behavior of the different gases not being of sufficient importance to have much weight in any consideration of their relative merits for use in domestic appliances. 
3. ADJUSTMENT IN APPLIANCES NECESSARY TO GIVE THE CONSUMERS GOOD AND EFFICIENT SERVICE, WHEN DIFFERENT KINDS OF GASES ARE MIXED AND THE COMPOSITION, HEATING VALUE, AND THE SPECIFIC GRAVITY CHANGE.

The development in the coke-oven processes with the production of by-product gas, the building of combination coal and water gas plants, and the necessity of supplementing natural gas with different kinds of manufactured gas has resulted in the delivery of mixed gases in many localities. The variation in heating value and specific gravity of the mixed gas may cause service troubles, unless the appliances are properly adjusted.

It is possible by a correct adjustment of appliances to maintain good service even with considerable variation in the gravity. The burners must be adjusted for an average condition which will permit them to be operated under all conditions within the three limitations prescribed for good service. These limitations are:

(I) The adjustment must be such that in changing to the heavier gas the rate in $\mathrm{B}$. $\mathrm{t} . \mathrm{u}$. per hour will not be reduced below a certain minimum which experience has shown is necessary for good service.

(2) The adjustment must be such that when the burners are operated with the heavier gas, the air injection is not too great to cause the burners to flash back when operated at low rates of consumption.

(3) The adjustment must be such that when the burners are operated with the light gas, which results in increased gas rate and reduced air injection, the flames will not be yellow, odors will not be produced, nor the utensils or mantles blackened.

If a burner is adjusted when the composition of the gas represents equal proportions of two gases of widely different specific gravity, no difficulty should be experienced in operating the appliance with either the high or low specific gravity gas, since the effect of changing to one or the other will not change the rate in B. t. u. per hour nor the flame characteristics sufficiently to cause poor service or loss in efficiency.

If a burner is adjusted when the gas consists mostly of the heavier gas, the best average adjustment would be secured by regulating the gas rate slightly below the normal rate and by setting the air shutter to give a flame harder than a "normal" flame. If, on the other hand, the gas consists mostly of the lighter gas at the time the burner adjustment is made, the best 
average adjustment would be obtained by regulating the gas rate to slightly above a normal rate and by setting the air shutter to produce a flame softer than a "normal" flame.

In addition to the methods suggested for making a good average adjustment, other methods may be found practicable. Some change in gas pressure or heating value to compensate for changes in specific gravity might be feasible so as to maintain the required amount of heat at the appliance and yet secure a satisfactory flame.

It is quite practicable, therefore, for appliance fitters to adjust domestic range bumers so that the service will be satisfactory and there will be no appreciable loss in efficiency, even though the heating value, the specific gravity, and pressure vary over considerable limits. Certain types of gas lamps and industrial appliances which demand a rather constant B. t. u. rate per hour would not operate as satisfactorily under these conditions. In general, the less variation there is in heating value, composition, specific gravity, and gas pressure, the easier it is to adjust the appliances to the most ideal condition and the more satisfactory will be the service.

\section{ACKNOWLEDGMENT.}

Among those who assisted by advice and cooperation in the tests are Mr. A. I. Phillips, gas engineer, American Gas Association; W. F. Strouse, chief engineer, Public Service Commission of Maryland; C. C. Winterstein, United Gas Improvement Co.; and L. W. Herbst, F. J. Piessner, and F. J. Ikena, of the Consolidated Gas, Electric Light \& Power Co. In addition, A. T. Larson and A. C. White, of the Fixed Nitrogen Research Laboratories, War Department, gave valuable advice concerning the design and operation of the apparatus shown in Figure 8, which was used to determine the carbon monoxide in the products of combustion from burners.

Washington, June 3, I922. 
